\title{
Utilization of Metabolite Identification and Structural Data to Guide Design of Low Dose IDO1 Inhibitors
}

\author{
Brett Hopkins, ${ }^{\dagger}$ Hongjun Zhang, ${ }^{\dagger}$ Indu Bharathan,${ }^{\dagger}$ Derun $\mathrm{Li},{ }^{\dagger}$ Qinglin $\mathrm{Pu},{ }^{\dagger}$ Hua Zhou, ${ }^{\dagger}$ \\ Theodore A. Martinot, ${ }^{\square}$ Xavier Fradera, ${ }^{*}$ Alfred Lammens, ${ }^{*}$ Charles A. Lesburg, ${ }^{*}$ Ryan D. \\ Cohen, ${ }^{\ddagger}$ Jeanine Ballard, $\square$ Ian Knemeyer, $\square$ Karin Otte, $\square$ Stella Vincent, $\square$ J. Richard Miller, $\$$ \\ Nicolas Solban,§ Mangeng Cheng,§ Prasanthi Geda,§ Nadya Smotrov,§ Xuelei Song,§ David \\ Jonathan Bennett, ${ }^{\dagger}$ Yongxin Han*† \\ Departments of ${ }^{\dagger}$ Discovery Chemistry, $\square$ Pharmacokinetics, Pharmacodynamics, and Drug Metabolism, \\ \#Computational and Structural Chemistry, ${ }^{\#}$ Discovery Process Chemistry, \$Pharmacology, Merck \& Co., Inc., \\ 33 Avenue Louis Pasteur, Boston, Massachusetts, 02115, United States. \\ $\ddagger$ Analytical Research and Development, Merck \& Co., Inc., Rahway, New Jersey, 07065, United States. \\ *Proteros biostructures, GmbH, Bunsenstraße 7a, D-82152 Planegg-Martinsried, Germany.
}

\section{Supporting Information}

\section{Table of Contents}

1.) IDO1 Protein Preparation

2.) IDO1 Human Whole Blood Assay Protocol

3.) Metabolite Identification Experimental

4.) Preparation of key compound $\mathbf{4}$ and $\mathbf{5}$

5.) Preparation of key compound 6

6.) In Vivo PK Protocol and Animal Care Statements

7.) Crystallography

8.) Prediction of Human Pharmacokinetic Parameters and Dose

9.) In vivo PKPD protocol

10.) Determination of absolute stereochemistry of compounds 5 and 6 using NMR and VCD 


\section{ID01 Protein Preparation}

IDO1 was expressed in E. coli (Lucigen C41(DE3) at $37^{\circ} \mathrm{C}$ using a LEX system in LB media until a OD600 of 0.8 was reached. Cells were induced with $0.5 \mathrm{mM}$ IPTG and supplemented with $0.75 \mathrm{mM} 5$ - aminolevulinic acid and $0.1 \mathrm{mM}$ thiamine- $\mathrm{HCl}$. Cells were then grown at $27^{\circ} \mathrm{C}$ for an additional $\sim 19 \mathrm{hrs}$. (overnight) before harvesting and freezing. Cells were resuspended in Lysis buffer $(25 \mathrm{mM}$ Tris-HCl pH 7.5, $150 \mathrm{mM} \mathrm{NaCl}, 20 \mathrm{mM}$ Imidazole, 40 U/ml Universal Nuclease (Pierce), complete Protease inhibitor cocktail EDTA-free (1/50ml), $1 \mathrm{mM}$ AEBSF, $1 \mathrm{mM}$ TCEP and lysed using a microfluidizer. The lysate was centrifuged at $45000 \mathrm{xg}$ for 25 minutes at $4{ }^{\circ} \mathrm{C}$ and loaded onto a HisTrap FF crude column previously equilibrated with IMAC buffer (25 mM Tris- $\mathrm{HCl}$ pH 7.5, 150 mM NaCl, $20 \mathrm{mM}$ Imidazole, $1 \mathrm{mM}$ TCEP). After washing, the protein was eluted with a gradient to $100 \%$ IMAC buffer containing $500 \mathrm{mM}$ imidazole. The proteins were desalted using a HiPrep 26/10 desalting column equilibrated in 25 $\mathrm{mM}$ Tris- $\mathrm{HCl} \mathrm{pH} \mathrm{7.5,} 150 \mathrm{mM} \mathrm{NaCl}, 1 \mathrm{mM}$ EDTA, and $1 \mathrm{mM}$ TCEP. Following desalting the protein was loaded onto a superdex-200 16/60 SEC column using the same buffer. Fractions were analyzed by gel electrophoresis and for heme content based on the ratio of absorbance at $406 / 280 \mathrm{~nm}$. Fractions with the greatest purity and heme content were pooled and concentrated to $1-5 \mathrm{mg} / \mathrm{mL}$ using $10 \mathrm{kD}$ cutoff Amicon spin concentrators. Heme stoichiometry varied from 0.8-0.95 heme per IDO1 molecule.

\section{ID01 Human Whole Blood Assay Protocol}

Compounds to be tested were serially diluted in ten 3-fold steps in DMSO starting from $10 \mathrm{mM} .3 \mu \mathrm{L}$ of compound dilutions or DMSO alone were then dispensed from the dilution plate into a polypropylene 96-well assay plate containing $97 \mu \mathrm{L}$ of RPMI using an Echo 555 acoustic liquid handler (Labcyte). LPS and IFNy was prepared in RPMI to a 10X of final conc. (1000 $\mathrm{ng} / \mathrm{mL}$ ), final concentration is $100 \mathrm{ng} / \mathrm{mL}$. Human whole blood was drawn in sodium heparin coated tubes from healthy internal donors. $240 \mu \mathrm{L}$ of blood was transferred to each of the wells of a v-bottom 96 well plate. $30 \mu \mathrm{L}$ of compound was transferred from intermediate dilution plate, and incubated for $15 \mathrm{~min} .30 \mu \mathrm{L}$ from stimulants was then transferred to blood and mixed thoroughly. Plate was covered with breathable membrane and incubated at $37^{\circ} \mathrm{C}$ for overnight $(18 \mathrm{~h})$. On day 2 isotope labeled standard of kynurenine and tryptophan was made in water at $10 \mathrm{x}$ concentration and $30 \mu \mathrm{L}$ was added to the blood at $3 \mu \mathrm{M}$ final concentration. The assay plates were centrifuged at $300 \times \mathrm{xG}$ for $10 \mathrm{~min}$ with no brake to separate plasma from red blood cells. $60 \mu \mathrm{L}$ of plasma samples was removed without disturbing red blood cells. Plasma was diluted with RPMI in 1:1 ratio and proteins were precipitated out with two volume of Acetonitrile. The plates was centrifuged at $4000 \times \mathrm{x}$ for $60 \mathrm{~min}$. $20 \mu \mathrm{L}$ of supernatant was carefully transferred to a 384 well plate containing $40 \mu \mathrm{L}$ of $0.1 \%$ formic acid in water and analyzed by LC/MS/MS. LC/MS/MS analyses were performed using Thermo Fisher's LX4-TSQ Quantum Ultra system. This system consists of four Agilent binary high-performance liquid chromatography (HPLC) pumps and a TSQ Quantum Ultra triple quadruple MS/MS instrument. For each sample, $5 \mu \mathrm{L}$ were injected onto an Atlantis T3 column $(2.1 \mathrm{~mm} \times 150 \mathrm{~mm}, 3 \mu \mathrm{m}$ particle size) from Waters. The mobile phase gradient pumped at $0.8 \mathrm{~mL} / \mathrm{min}$ was used to elute the analytes from the 
column at $25{ }^{\circ} \mathrm{C}$. The elution started at $0 \%$ B increasing linearly to $25 \% \mathrm{~B}$ at $6.5 \mathrm{~min}$, holding at $25 \%$ for $1 \mathrm{~min}$, re-equilibrating to $10 \mathrm{~min}$. Mobile phase A consisted of $0.1 \%$ formic acid in water. Mobile phase $B$ consisted of $0.1 \%$ of formic acid in acetonitrile. Data was acquired in positive mode using a HESI interface. The operational parameters for the TSQ Quantum Ultra instrument were a spray voltage of $4000 \mathrm{~V}$, capillary temperature of $380^{\circ} \mathrm{C}$, vaporizer temperature $400{ }^{\circ} \mathrm{C}$, shealth gas 60 arbitrary units, Aux gas 20 arbitrary units, tube lens 85 and collision gas 1.2 mTorr. SRM chromatograms of kynurenine (Q1: 209.2>Q3:94.0) and internal standard (Q1: 215.3>Q3:98.2) were collected for 90 seconds. The peak area was integrated by Xcalibur Quan software. The ratios between the kynurenine generated in the reaction and 2D6Kynurenine spiked-in internal standard were used to generate percentage inhibition and IC50 values. Compounds were titrated and IC50s were calculated by 4 parameter sigmoidal curve fitting formula. . IC50 values reported are the mean of at least $n=2$ values unless otherwise noted, and potency values differed by less than 3- fold, otherwise additional replicate data were collected.

\section{Metabolite Identification Experimental}

Rat and Human Hepatocyte Incubations. The experiments were performed in 96-well plates at $37^{\circ} \mathrm{C}$. Test articles at a concentration of $2 \mathrm{mM}$ in pure DMSO were diluted 1:1000 in $8.5 \% \mathrm{DMSO}$ in acetonitrile to $30 \mu \mathrm{M}$. This solution $(2 \mu \mathrm{L})$ was added to $198 \mu \mathrm{L}$ of human or rat liver hepatocytes (1 million viable cells $/ \mathrm{mL}$ ) suspended in glutamine enriched Williams' Medium E. At specific reaction time points $(0,15,30,60$ and $90 \mathrm{~min})$, aliquots $(20 \mu \mathrm{L})$ were removed and reactions were terminated by the addition to acetonitrile ( $40 \mu \mathrm{L}$, with $100 \%$ acetonitrile) containing the analytical internal standards (200 nM diclofenac, $200 \mathrm{nM}$ labetalol, and $200 \mathrm{nM}$ imipramine) and mixed well. Samples were centrifuged for $20 \mathrm{~min}$, after which a $40 \mu \mathrm{L}$ aliquot was transferred to a clean plate and $40 \mu \mathrm{L}$ of MilliQ water was added, mixed and injected for LC/MS analysis. The rate of parent elimination was estimated, relative to time zero minute incubation, is used to estimate the in vitro elimination-rate constant (kmic), which is used to calculate the in vitro metabolic clearance rates.3 LC-MS/MS Analysis. Analysis of samples was performed on a high performance liquid chromatography tandem mass spectrometry (LCMS/MS) system consisting of a Thermo QE HF mass spectrometer with an electrospray ion source from Thermo Fisher Scientific Inc. (Waltham, MA). Samples were separated on a Waters Acquity BEH C18, $2.1 \mathrm{~mm} \times 100 \mathrm{~mm}, 1.7 \mu \mathrm{m}$. The components were eluted with a gradient of $0.1 \%$ formic acid (mobile phase $A$ ) versus $0.1 \%$ formic acid in acetonitrile (mobile phase $B$ ) at a flow of $500 \mu \mathrm{L} / \mathrm{min}$ using the following gradient: $0 \min 5 \% \mathrm{~B} ; 0.5 \mathrm{~min} 5 \% \mathrm{~B} ; 1.25 \mathrm{~min} 15 \% \mathrm{~B}$; $2.75 \min 50 \%$ B; $3.25 \min 95 \%$ B; $3.5 \min 95 \%$ B; $3.6 \min 5 \%$ B; $5.0 \mathrm{~min} 5 \%$ B. The injection volume was $20 \mu \mathrm{L}$. The first $1.5 \mathrm{~min}$ of eluent were diverted to waste to protect an ion source from salts and polar impurities from the incubation. Predictions of metabolites were done with MetaSite 3.0 (Molecular Discovery Ltd., Middlesex, UK, www.moldiscovery.com) using the P450 liver model, reactivity correction, and a minimal mass threshold of $100 \mathrm{Da}$ for predicted metabolites. The P450 liver model displays a consensus of the SoM predictions of the three major liver isoforms CYP3A4, CYP2D6, and CYP2C9. Stereochemistry was ignored and the smaller part of complementary metabolites (cleavage) was rejected. The predicted metabolites were exported as text-file, which was used to automatically calculate, together with parent fragment information, metabolite specific selected reaction monitoring functions (SRM) for mass 
spectrometry analysis. The most likely structure of the product ions was determined with the help of using MetaSite integrated into our WebMetabase software (Molecular Discovery Ltd., Middlesex, UK) when needed.

\section{Preparation of key compound 4 and 5}
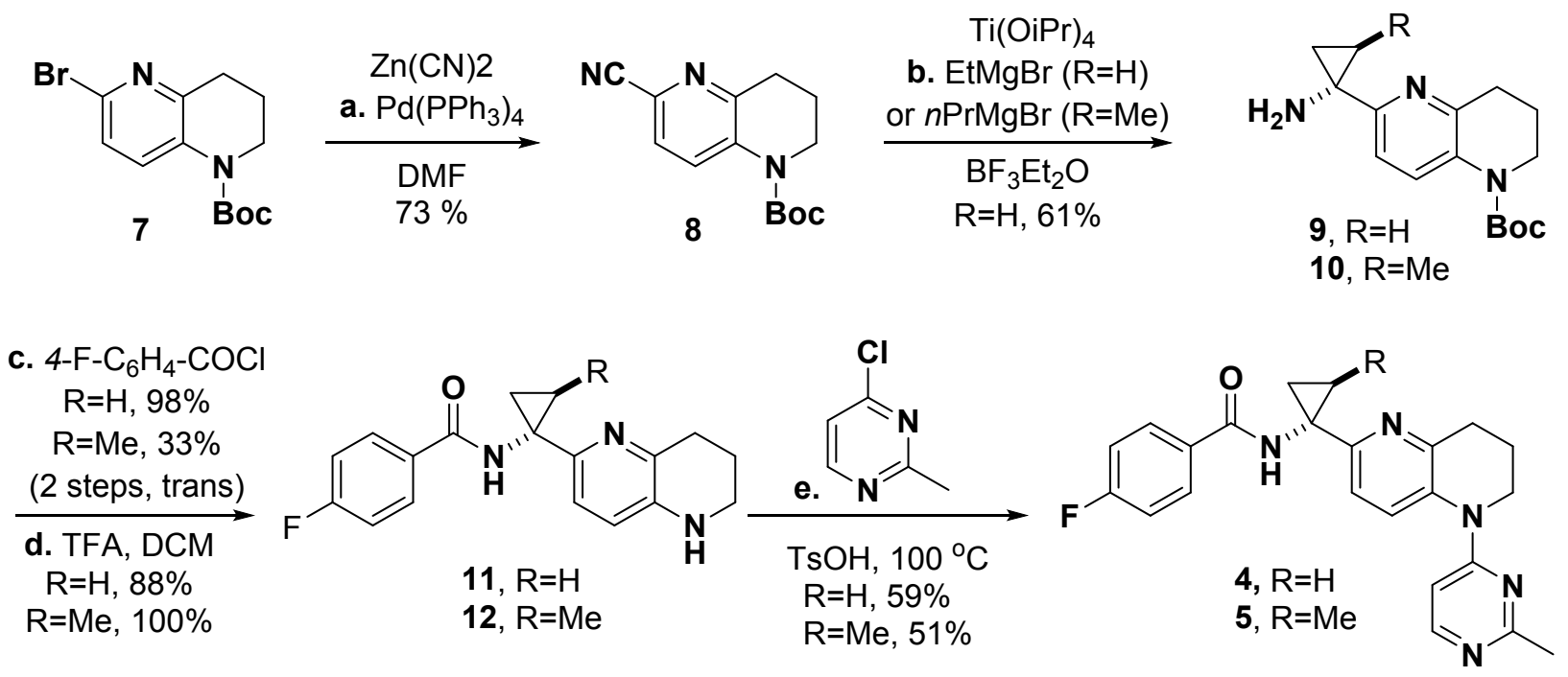

Intermediate 8: tert-butyl 6-cyano-3,4-dihydro-1,5-naphthyridine-1(2H)-carboxylate<smiles>N#Cc1ccc2c(n1)CCCN2C(=O)O</smiles>

To a stirred solution of tert-butyl 6-bromo-3,4-dihydro-I,5-naphthyridine-I(2H)- carboxylate ( 500 $\mathrm{mg}, 1.596 \mathrm{mmol})$ in DMF ( $10 \mathrm{~mL}$ ) were added cyanozinc $(680 \mathrm{mg}, 7.44 \mathrm{mmol})$ and $\mathrm{Pd}\left(\mathrm{PPh}_{3}\right)_{4}$ (184 mg, $0.160 \mathrm{mmol}$ ) at $20^{\circ} \mathrm{C}$. After the addition, the reaction was stirred at $100{ }^{\circ} \mathrm{C}$ The reaction was monitored by LC-MS and the reaction was finished after stirring at $100{ }^{\circ} \mathrm{C}$ for $16 \mathrm{~h}$. The reaction mixture was cooled to RT, extracted by EtOAc ( $80 \mathrm{~mL} \times 3$ ), the organic layers were collected, washed with brine ( $50 \mathrm{~mL}$ ), and dried over sodium sulfate. After filtration, the filtrate was concentrated in vacuo. The residue was purified by flash silica gel chromatography eluting with a gradient of $0-30 \%$ Ethyl acetate in petroleum ether to give the title compound as a solid (302 mg, 73\%). MS ESI calcd. for $\mathrm{C}_{14} \mathrm{H}_{17} \mathrm{~N}_{3} \mathrm{O}_{2}[\mathrm{M}+\mathrm{H}]+260.1$; found 260.1.

Intermediate 9: tert-butyl 6-(1-aminocyclopropyl)-3,4-dihydro-1,5-naphthyridine-1(2H)carboxylate<smiles>CC(C)(C)OC(=O)N1CCCc2nc(C3(N)CC3)ccc21</smiles> 
To a solution of tert-butyl 6-cyano-3,4-dihydro-l,5-naphthyridine-l(2H)- carboxylate (350 mg, $1.350 \mathrm{mmol})$ and $\mathrm{Ti}(\mathrm{i}-\mathrm{PrO})_{4}(422 \mathrm{mg}, 1.485 \mathrm{mmol})$ in THF $(10 \mathrm{~mL})$ was added ethylmagnesium bromide ( $0.9 \mathrm{~mL}, 2.70 \mathrm{mmol}$ ) dropwise with stirring at $-70{ }^{\circ} \mathrm{C}$ under nitrogen atmosphere. After the addition, the reaction mixture was stirred at $-70^{\circ} \mathrm{C}$ for $30 \mathrm{~min}$ and then at $20^{\circ} \mathrm{C}$ for $1 \mathrm{~h}$. Then, $\mathrm{BF}_{3} \mathrm{Et}_{2} \mathrm{O}$ ( $\left.0.35 \mathrm{~mL}, 2.76 \mathrm{mmol}\right)$ was added slowly. The reaction mixture was stirred at 20 ${ }^{\circ} \mathrm{C}$ for $14 \mathrm{~h}$. The reaction was monitored by LC-MS and after stirring at $20^{\circ} \mathrm{C}$ for $14 \mathrm{~h}$, the reaction was finished. The mixture was quenched by the addition of water $(100 \mathrm{~mL})$, and extracted by EtOAc ( $80 \mathrm{~mL} \times 3)$. The organic layers were collected, washed with brine $(50 \mathrm{~mL})$, and dried over sodium sulfate. After filtration, the filtrate was concentrated in vacuo to give the title compound as an oil ( $238 \mathrm{mg}, 61 \%$ ) which was used in the next step without any further purification. MS ESI calcd. for $\mathrm{C}_{16} \mathrm{H}_{23} \mathrm{~N}_{3} \mathrm{O}_{2}[\mathrm{M}+\mathrm{H}]+290.2$; found 290.2.

Intermediate 11: 4-fluoro-N-(1-(5,6,7,8-tetrahydro-1,5-naphthyridin-2-yl)cyclopropyl)benzamide<smiles>O=C(NC1(c2ccc3c(n2)CCCN3)CC1)c1ccc(F)cc1</smiles>

To a stirred solution of tert-butyl 6-(I-aminocyclopropyl)-3,4-dihydro-l,5- naphthy ridine- 1 (2H)carboxy late $(350 \mathrm{mg}, 0.605 \mathrm{mmol})$ in DMF $(5 \mathrm{~mL})$ were added 4- fluorobenzoic acid $(85 \mathrm{mg}$, $0.605 \mathrm{mmol})$, HATU $(230 \mathrm{mg}, 0.605 \mathrm{mmol})$ and DIPEA $(0.32 \mathrm{~mL}, 1.832 \mathrm{mmol})$ at $20^{\circ} \mathrm{C}$. After the addition, the reaction was stirred at $20^{\circ} \mathrm{C}$ and the reaction was monitored by LC-MS. After stirring at $20^{\circ} \mathrm{C}$ for $2 \mathrm{~h}$, the reaction was finished. To the mixture was added water ( $200 \mathrm{~mL}$ ), and it was extracted by EtOAc ( $80 \mathrm{~mL} \times 3)$. The organic layers were collected, washed with brine $(50 \mathrm{~mL})$, and dried over sodium sulfate. After filtration, the filtrate was concentrated in vacuo The residue was purified by flash silica gel chromatography eluting with a gradient of 0 $30 \%$ Ethyl acetate in petroleum ether to give the desired compound as an oil (244 $\mathrm{mgs}, 98 \%$ ). MS ESI calcd. for $\mathrm{C}_{23} \mathrm{H}_{26} \mathrm{FN}_{3} \mathrm{O}_{3}[\mathrm{M}+\mathrm{H}]+412.2$; found 412.1.

To a stirred solution of -butyl 6-(I-(4-fluorobenzamido)cyclopropyl)-3,4- dihydro-I,5naphthyridine-l $(2 \mathrm{H})$-carboxylate $(85 \mathrm{mg}, 0.207 \mathrm{mmol})$ in DCM $(5 \mathrm{~mL}$ ) was added TFA ( $1 \mathrm{~mL}$, $12.98 \mathrm{mmol}$ ) at $15^{\circ} \mathrm{C}$. After the addition, the reaction was stirred at $15^{\circ} \mathrm{C}$. The reaction was monitored by LC-MS. After stirring at $15^{\circ} \mathrm{C}$ for $16 \mathrm{~h}$, the reaction was complete. The mixture was concentrated under reduced pressure to give the title compound as an oil ( $57 \mathrm{mg}, 88 \%$ ). MS ESI calcd. for $\mathrm{C}_{18} \mathrm{H}_{18} \mathrm{FN}_{3} \mathrm{O}[\mathrm{M}+\mathrm{H}]+312.1$; found 312.1.

4: 4-fluoro-N-(1-(5-(2-methylpyrimidin-4-yl)-5,6,7,8-tetrahydro-1,5-naphthyridin-2yl)cyclopropyl)benzamide 
<smiles>Cc1nccc(N2CCCc3nc(C4(NC(=O)c5ccc(F)cc5)CC4)ccc32)n1</smiles>

To a vial containing 4-fluoro-N-(I-(5,6,7,8-tetrahydro-I,5-naphthyridin-2- yl)cyclopropyl) benzamide (57 mg , $0.18 \mathrm{mmol}$ ), 4-chloro-2-methylpyrimidine (46 mg, $0.36 \mathrm{mmol}$ ) and 4methylbenzenesulfonic acid (34 $\mathrm{mg}, 0.20 \mathrm{mmol}$ ) was added dioxane $(2 \mathrm{ml})$. The mixture was heated at $100{ }^{\circ} \mathrm{C}$ for $14 \mathrm{~h}$. The mixture was cooled down, neutralized with saturated sodium bicarbonate, and extracted wtih DCM. The combined organics were dried over magnesium sulfate and concentrated. The residue was purified by flash chromatography on silica gel [0$100 \%$ (l:3EtOH/EtOAc) in hexanes] to give the desired product as a white solid (42 $\mathrm{mg}, 59 \%$ ). 'HNMR (600 MHz, DM SO-d6) ס $9.27(\mathrm{~s}, 1 \mathrm{H}), 8.19$ (d, J = 6.1 Hz, 1H), 8.01 (dd, J = 8.3, $5.7 \mathrm{~Hz}$, $2 \mathrm{H}), 7.79(\mathrm{~d}, \mathrm{~J}=8.5 \mathrm{~Hz}, 1 \mathrm{H}), 7.33(\mathrm{t}, \mathrm{J}=8.7 \mathrm{~Hz}, 2 \mathrm{H}), 7.14(\mathrm{~d}, \mathrm{~J}=8.5 \mathrm{~Hz}, 1 \mathrm{H}), 6.80(\mathrm{~d}, \mathrm{~J}=6.1$ $\mathrm{Hz}, 1 \mathrm{H}), 3.86(\mathrm{t}, \mathrm{J}=5.9 \mathrm{~Hz}, 2 \mathrm{H}), 2.81(\mathrm{t}, \mathrm{J}=6.5 \mathrm{~Hz}, 2 \mathrm{H}), 2.41(\mathrm{~s}, 3 \mathrm{H}), 1.95(\mathrm{~m}, 2 \mathrm{H}), 1.52(\mathrm{~m}$, $2 \mathrm{H}), 1.23(\mathrm{~m}, 2 \mathrm{H}) .{ }^{13} \mathrm{C}$ NMR (151 MHz, DMSO- $\left.d_{6}\right) \delta 166.56,166.05,164.00$ (d, J = 248.6 Hz), 160.60, 156.33, 155.61, 150.10, 132.17, 130.81 (d, $J=2.8 \mathrm{~Hz}), 130.27,130.06$ (d, J = $9.0 \mathrm{~Hz}$ ), 116.52, 115.20 (d, $J=21.8 \mathrm{~Hz}), 102.93,44.43,40.05,35.91,30.10,25.82,22.70,18.46$

LRMS (ESI) calc'd for $\mathrm{C}_{23} \mathrm{H}_{22} \mathrm{FN}_{5} \mathrm{O}[\mathrm{M}+\mathrm{H}]^{+}$404.2; found 404.2. $\mathrm{HRMS}$ (EI) calc'd for $\mathrm{C}_{23} \mathrm{H}_{23} \mathrm{FN}_{5} \mathrm{O}$ $[\mathrm{M}+\mathrm{H}]^{+}$, 404.1887; found, 404.1887.

Intermediate 10: tert-butyl 6-((1R,2R)-1-amino-2-methylcyclopropyl)-3,4-dihydro-1,5naphthyridine-1(2H)-carboxylate

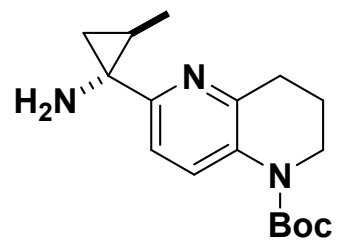

To a solution of tert-butyl 6-cyano-3,4-dihydro-I,5-naphthyridine-I $(2 \mathrm{H})$ - carboxylate $(1 \mathrm{~g}, 3.86$ $\mathrm{mmol})$ in 2-MeTHF $(12.85 \mathrm{ml})$ at RT was added Titanium(IV) isopropoxide $(1.370 \mathrm{ml}, 4.63$ $\mathrm{mmol})$, followed by the addition of N-propylmagnesium chloride $(9.26 \mathrm{ml}, 9.26 \mathrm{mmol})$. The reaction was slightly exothermic during the addition. Water bath was used to maintain internal temp below $30^{\circ} \mathrm{C}$. After the addition, the reaction mixture was kept stirring at RT for 30 min. Then Boron trifluoride diethyl etherate ( $1.142 \mathrm{ml}, 9.26 \mathrm{mmol}$ ) was added while maintaining internal temperature under $35^{\circ} \mathrm{C}$ during the addition by cooling with water bath. The mixture was kept stirring for $30 \mathrm{~min}$. The mixture was quenched by pouring slowly into a beaker containing $5 \mathrm{ml} \mathrm{IM} \mathrm{NaOH}$ and $5 \mathrm{ml}$ of water and extracted with 1:1 EtOAc/2-MeTHF $100 \mathrm{ml} \times 3$. 
The combined organics were dried over sodium sulfate, and concentrated. The title compound was carried over to next step. MS ESI calcd. for $\mathrm{C}_{17} \mathrm{H}_{25} \mathrm{~N}_{3} \mathrm{O}_{2}[\mathrm{M}+\mathrm{H}]+304.2$; found 304.2.

Intermediate 12: 4-fluoro-N-((1R,2R)-2-methyl-1-(5,6,7,8-tetrahydro-1,5-naphthyridin-2yl)cyclopropyl)benzamide<smiles>CC1C[C@]1(NC(=O)c1ccc(F)cc1)c1ccc2c(n1)CCCN2</smiles>

To a solution of tert-butyl 6-(I-amino-2-methylcyclopropyl)-3,4-dihydro-I,5- naphthyridine-I(2H)carboxylate $(1.17 \mathrm{~g}, 3.86 \mathrm{mmol})$ in $\mathrm{DCM}(12.85 \mathrm{ml})$ at $\mathrm{RT}$ was added $\mathrm{Et}_{3} \mathrm{~N}(2.150 \mathrm{ml}, 15.43$ $\mathrm{mmol})$, followed by the addition of 4 -fluorobenzoyl chloride $(0.183 \mathrm{ml}, 1.543 \mathrm{mmol})$. The mixture was stirred at RT for 20 min. LCMS showed complete conversion. The reaction mixture was diluted with saturated sodium bicarbonate, and extracted with DCM. The organic layer was separated, washed with brine, dried over magnesium sulfate, and concentrated. The residue was purified by flash chromatography (0-100\% EtOAc in hexanes) to give two peaks (542 mg, $33 \%$ over 2 steps (cis and trans combined yield). Peak 1 was the cis isomer and Peak 2 was the trans isomer. MS ESI calcd. for $\mathrm{C}_{24} \mathrm{H}_{28} \mathrm{FN}_{3} \mathrm{O}_{3}[\mathrm{M}+\mathrm{H}]+426.2$; found 426.1 (same data for cis and trans peaks).

To a flask containing tert-butyl 6-((1R,2R)-I-(4-fluorobenzamido)-2- methylcyclopropyl)-3,4dihydro-I,5-naphthyridine-I(2H)-carboxylate (peak 2 trans material from previous step, $275 \mathrm{mg}$, $0.646 \mathrm{mmol}$ ) was added $\mathrm{HC} 1,4 \mathrm{M}$ in dioxane (1061 $\mu \mathrm{ï,} 4.25 \mathrm{mmol}$ ). The mixture was stirred at RT for $14 \mathrm{~h}$, neutralized with saturated sodium bicarbonate, and extracted with DCM. The combined organics were dried over magnesium sulfate, and concentrated to give the title compound (210 mg, 100\%). MS ESI calcd. for $\mathrm{C}_{19} \mathrm{H}_{20} \mathrm{FN}_{3} \mathrm{O}[\mathrm{M}+\mathrm{H}]+326.2$; found 326.2.

5: 4-fluoro-N-((1R,2R)-2-methyl-1-(5-(2-methylpyrimidin-4-yl)-5,6,7,8-tetrahydro-1,5naphthyridin-2-yl)cyclopropyl)benzamide<smiles>Cc1nccc(N2CCCc3nc(C4(NC(=O)c5ccc(F)cc5)CC4C)ccc32)n1</smiles>

A mixture of 4-fluoro-N-((1R,2R)-2-methyl-1-(5,6,7,8-tetrahydro-1,5-naphthyridin-2yl)cyclopropyl)benzamide (210 mg, $0.645 \mathrm{mmol}$ ), 4-chloro-2- methylpyrimidine (166 mg, 1.291 $\mathrm{mmol}$ ), and 4-methylbenzenesulfonic acid (122 $\mathrm{mg}, 0.710 \mathrm{mmol})$ in dioxane $(3.25 \mathrm{~mL})$ was heated at $100{ }^{\circ} \mathrm{C}$ for $14 \mathrm{~h}$. The mixture was cooled down and neutralized with saturated sodium bicarbonate, and extracted with DCM. The combined organics were dried over magnesium sulfate, and concentrated. The residue was purified by flash chromatography $(0-80 \%)(1: 3$ 
$\mathrm{EtOH} / \mathrm{EtOAc}$ )/hexanes) to give the title compound as a mixture of enantiomers (137 $\mathrm{mg}, 51 \%$ ). The relative stereochemistry was determined to be trans ( $\mathrm{NH}$ vs $\mathrm{Me}$ ). The material was chirally separated to give two enantiomers. Column \& dimensions (mm): OJ-H, 21 x 250 (220nm Outlet Pressure (bar): 100; UV wavelength (nm): 220; Flow rate (ml/min): 70 Modifier: $\mathrm{MeOH}$ w/ 0.25\% DMEA; \% modifier in C02: 15; Diluent: $\mathrm{MeOH}$ Retention time $(\min ): 2.4,3.5$. The title compound 5 was peak 1. ${ }^{1} \mathrm{H}$ NMR $(600 \mathrm{MHz}$, DMSO-d $) \delta 9.33(\mathrm{~s}, 1 \mathrm{H}), 8.21(\mathrm{~d}, J=6.1 \mathrm{~Hz}, 1 \mathrm{H}), 7.98(\mathrm{dd}, J$ $=8.3,5.7 \mathrm{~Hz}, 2 \mathrm{H}), 7.84(\mathrm{~d}, J=8.6 \mathrm{~Hz}, 1 \mathrm{H}), 7.38-7.24(\mathrm{~m}, 3 \mathrm{H}), 6.82(\mathrm{~d}, J=6.1 \mathrm{~Hz}, 1 \mathrm{H}), 4.02-$ $3.75(\mathrm{~m}, 2 \mathrm{H}), 2.97-2.77(\mathrm{~m}, 2 \mathrm{H}), 2.42(\mathrm{~s}, 3 \mathrm{H}), 1.96(\mathrm{p}, J=6.2 \mathrm{~Hz}, 2 \mathrm{H}), 1.76(\mathrm{dd}, J=7.1,4.9$ $\mathrm{Hz}, 1 \mathrm{H}), 1.61(\mathrm{~d}, J=8.8 \mathrm{~Hz}, 1 \mathrm{H}), 1.13(\mathrm{dd}, J=9.3,4.6 \mathrm{~Hz}, 1 \mathrm{H}), 0.98(\mathrm{~d}, J=6.2 \mathrm{~Hz}, 3 \mathrm{H}) .{ }^{13} \mathrm{C}$ NMR (126 MHz, DMSO- $\left.d_{6}\right) \delta$ 166.58, 165.56, 163.93 (d, $\left.J=248.6 \mathrm{~Hz}\right), 160.57,156.41,153.70$, 148.70, 132.39, 130.91 (d, $J=2.8 \mathrm{~Hz}$ ), 130.12, 129.99 (d, $J=9.0 \mathrm{~Hz}), 119.41,115.16$ (d, $J=$ $21.8 \mathrm{~Hz}), 103.05,66.35,44.43,30.12,25.85,23.44,22.71,20.75,12.43$.

HRMS (El) calc'd for $\mathrm{C}_{24} \mathrm{H}_{25} \mathrm{FN}_{5} \mathrm{O}[\mathrm{M}+\mathrm{H}]^{+}$, 418.2043; found, 418.2047.

\section{Preparation of key compound 6}

\section{Synthesis of compound 6:}<smiles>COc1ccc(Cn2c(=O)ccc3ncccc32)cc1</smiles>

13<smiles></smiles>

a. $\mathrm{NaH}$

rt- $65^{\circ} \mathrm{C}$, DMSO $61 \%$<smiles>COc1ccc(CN2C(=O)C3CC3c3ncccc32)cc1</smiles>

14
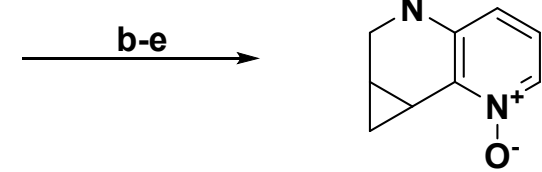

15

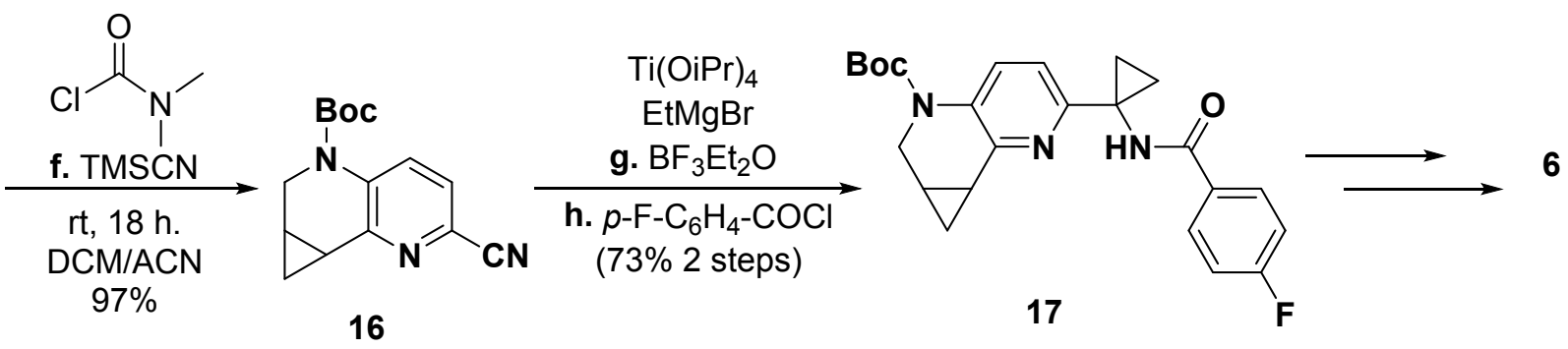

Synthesis of PMB starting material: 1-(4-methoxybenzyl)-1,5-napthyridin-2(1H)-one (13)<smiles>COc1ccc(Cn2c(=O)ccc3ncccc32)cc1</smiles> 
1,5-Napthyridin-2(1H)-one (110.0 g, $752.7 \mathrm{mmol}, 1.0 \mathrm{eq}$.) was added to a solution of DMF (770 $\mathrm{mL})$ in a $3 \mathrm{~L}$ three neck round bottom flask to give a suspension. $\mathrm{NaH}(31.6 \mathrm{~g}, 790.3 \mathrm{mmol}, 60 \%$ purity, 1.05 eq.) was added portion-wise at $20^{\circ} \mathrm{C}$ for $30 \mathrm{~min}$. The reaction was exothermic. This was allowed to stir at $40^{\circ} \mathrm{C}$ for another $1 \mathrm{~h}$. PMB-Cl $(147.3 \mathrm{~g}, 940.8 \mathrm{mmol}, 128.1 \mathrm{~mL}, 1.25 \mathrm{eq}$.) was added dropwise at $40{ }^{\circ} \mathrm{C}$. This was stirred at $50^{\circ} \mathrm{C}$ for another $2 \mathrm{~h}$. The reaction was cooled to $20^{\circ} \mathrm{C}$. $110 \mathrm{~mL}$ was added dropwise. The residue was poured into water $(3 \mathrm{~L})$, and extracted with EtOAc $(1 \mathrm{~L}, 500 \mathrm{~mL})$. The organic layers were combined and washed with brine $(500 \mathrm{~mL})$, dried over anhydrous sodium sulfate, and filtered. Excess solvent was removed under reduced pressure. This was purified on a silica gel column using gradient elution with petroleum ether/ethyl acetate $=20 / 1 \sim 0 / 1$. The title compound was obtained as a yellow solid $(290 \mathrm{~g}, 45 \%$ yield). MS ESI calcd. for $\mathrm{C}_{16} \mathrm{H}_{15} \mathrm{~N}_{2} \mathrm{O}_{2}[\mathrm{M}+\mathrm{H}]^{+} 267.1$, found 267.0

Step a: 5-(4-methoxybenzyl)-5,6a,7,7a-tetrahydro-6H-cyclopropa(c)\{1,5\}napthyridin-6-one (14)<smiles>COc1ccc(CN2C(=O)C3CC3c3ncccc32)cc1</smiles>

$\mathrm{NaH}(25.2 \mathrm{~g}, 630.9 \mathrm{mmol}, 60 \%$ purity, 2.1 eq.) was added to a solution of DMSO (1.3 L) in a 3-L three neck round bottom flask to give a suspension. Compound 4-1 was added portion wise (132.2 $\mathrm{g}, 600.8 \mathrm{mmol}, 2.0$ eq.) at $20^{\circ} \mathrm{C}$ and stirred at $60^{\circ} \mathrm{C}$ for $1 \mathrm{~h}$. 1-(4-Methoxybenzyl)-1,5-napthyridin$2(1 \mathrm{H})$-one,5-napthyridin-2(1H)-one was added drop wise $(80.0 \mathrm{~g}, 300.4 \mathrm{mmol}, 1.0 \mathrm{eq}$.) in DMSO $(240 \mathrm{~mL}) / \mathrm{THF}(80 \mathrm{~mL})$ at $60^{\circ} \mathrm{C}$ and allowed to stir at $60^{\circ} \mathrm{C} 25$ for $2 \mathrm{~h}$. The reaction mixture was diluted with water $(800 \mathrm{~mL})$ at $20^{\circ} \mathrm{C}$. The aq. phase was extracted with EtOAc $(2 \times 300 \mathrm{~mL})$. The organic layers were combined, washed with brine $(500 \mathrm{~mL})$, dried over $\mathrm{Na} 2 \mathrm{SO} 4$, filtered, and concentrated to dryness. This was purified on a silica gel column, eluting with petroleum ether/ethyl acetate $=20 / 1 \sim 1 / 1$ to give the title compound as a yellow solid $(105 \mathrm{~g}, 62 \%)$.MS ESI calcd. For $\mathrm{C}_{17} \mathrm{H}_{16} \mathrm{~N}_{2} \mathrm{O}_{2}[\mathrm{M}+\mathrm{H}]^{+}$281.1, found 281.1

Step b: 5-(4-methoxybenzyl)-6,6a,7,7a-tetrahydro-5H-cyclopropa\{c\}\{1,5\}napthyridine<smiles>COc1ccc(CN2CC3CC3c3ncccc32)cc1</smiles>

5-(4-Methoxybenzyl)-5,6a,7,7a-tetrahydro-6H-cyclopropa(c) \{1,5\}napthyridin-6-one (50.0 g, $178.4 \mathrm{mmol}, 1.0$ eq. $)$ was added to a solution of THF $(350 \mathrm{~mL})$ in a 2-L three neck round bottom flask. BH3- $\mathrm{Me}_{2} \mathrm{~S}(10 \mathrm{M}, 35.67 \mathrm{~mL}, 2.0$ eq. $)$ was added dropwise at $20^{\circ} \mathrm{C}$ for $30 \mathrm{~min}$ and allowed to stir at $60{ }^{\circ} \mathrm{C}$ for $1 \mathrm{~h}$ and then cooled to $20^{\circ} \mathrm{C}$. To this $\mathrm{MeOH}(59.4 \mathrm{~g}, 1.85 \mathrm{~mol}, 75.0 \mathrm{~mL}, 10.0$ 
eq.) was added at $20^{\circ} \mathrm{C}$ and then stirred at $60{ }^{\circ} \mathrm{C}$ for $4 \mathrm{~h}$. The reaction mixture was concentrated to dryness and the crude product was used in the next step without further purification. The title compound was obtained as a crude yellow solid (138 g crude product, from 9 reactions in parallel added together). MS ESI calcd. for $\mathrm{C}_{17} \mathrm{H}_{19} \mathrm{~N}_{2} \mathrm{O}[\mathrm{M}+\mathrm{H}]^{+} 267.1$, found 267.1.

Step c: 6,6a,7,7a-tetrahydro-5H-cyclopropa(c)\{1,5\}napthyridine

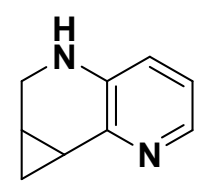

5-(4-methoxybenzyl)-6,6a,7,7a-tetrahydro-5H-cyclopropa $\{c\}\{1,5\}$ napthyridine $(46.0 \mathrm{~g}, 172.7$ $\mathrm{mmol}, 1.0$ eq.) was added to anisole $(186.8 \mathrm{~g}, 1.73 \mathrm{~mol}, 187.7 \mathrm{~mL}, 10.0$ eq.) in a 15 solution of DCE $(190 \mathrm{~mL})$ in a $500 \mathrm{~mL}$ three neck round bottom flask. To this TFA (295.4 g, $2.59 \mathrm{~mol}, 191.8$ $\mathrm{mL}, 15.0$ eq.) was added at $20^{\circ} \mathrm{C}$ and stirred at $20^{\circ} \mathrm{C}$ for $12 \mathrm{~h}$. The residue was poured into $1 \mathrm{~N}$ $\mathrm{HCl}(5 \mathrm{~L})$ and extracted with $\mathrm{DCM}(1 \mathrm{~L})$. The $\mathrm{pH}$ of the aqueous phase was adjusted to 13 14 with $\mathrm{NaOH}(200 \mathrm{~g})$, and this was extracted with DCM $(2 \mathrm{~L}, 1 \mathrm{~L})$. The organic layers were combined, washed with brine $(2 \mathrm{~L})$, dried over anhydrous sodium sulfate, filtered 20 and concentrated to dryness. The crude product was used in the next step without further purification. The title compound was obtained as an off white solid $(64 \mathrm{~g}$ from 3 reactions in parallel).

Step d: tert-butyl 6,6a,7,7a-tetrahydro-5H-cyclopropa(c)\{1,5\}napthyridine-5-carboxylate<smiles>CC(C)(C)OC(=O)N1CC2CC2c2ncccc21</smiles>

6,6a,7,7a-Tetrahydro-5H-cyclopropa(c)\{1,5\}napthyridine (32. g, $218.9 \mathrm{mmol}, 1.0$ eq.) was added to a solution of THF $(270 \mathrm{~mL})$ in a 1-L three neck round bottom flask. To the above solution LiHMDS (1 M, $218.9 \mathrm{~mL}, 1.0$ eq.) was added dropwise at $20^{\circ} \mathrm{C}$ for $10 \mathrm{~min}$. To this Boc2O $(71.7$ $\mathrm{g}, 328.3 \mathrm{mmol}, 75.4 \mathrm{~mL}, 1.5 \mathrm{eq}$.) was added dropwise at $20^{\circ} \mathrm{C}$ for $10 \mathrm{~min}$, and this was allowed to stir at $40{ }^{\circ} \mathrm{C}$ for $2 \mathrm{~h}$. The reaction mixture was poured into $1 \mathrm{~L}$ water. This was extracted with EtOAc $(2 \times 300 \mathrm{~mL})$. The organic layers were combined, washed with brine $(500 \mathrm{~mL})$, dried over anhydrous sodium sulfate, and filtered. Excess solvent was removed under 5 reduced pressure. The residue obtained was purified on a silica gel column using petroleum ether/ethyl acetate = 20/1 1/1. The title compound was obtained as a colorless oil $(84 \mathrm{~g}, 78 \%$ yield, from 2 reactions in parallel). ${ }^{1} \mathrm{HNMR}:\left(400 \mathrm{MHz} \mathrm{CDCl}_{3}\right) \delta$ : 8.22-8.29 (m, 1H), $7.61(\mathrm{~s}, 1 \mathrm{H}), 7.00-7.08(\mathrm{~m}, 1 \mathrm{H})$, $4.57(\mathrm{~d}, J=12.8 \mathrm{~Hz}, 1 \mathrm{H}), 2.93(\mathrm{~d}, J=12.8 \mathrm{~Hz}, 1 \mathrm{H}), 2.25-2.31(\mathrm{~m}, 1 \mathrm{H}), 1.98-2.00(\mathrm{~m}, 1 \mathrm{H}), 1.48$ $(\mathrm{s}, 9 \mathrm{H}), 1.12-1.64(\mathrm{~m}, 1 \mathrm{H}), 0.87-1.11(\mathrm{~m}, 1 \mathrm{H})$.

Step e: 5-(tert-butoxycarbonyl)-6,6a,7,7a-tetrahydro-5H-cyclopropa(c)\{1,5\}napthyridine-1-oxide (15) 


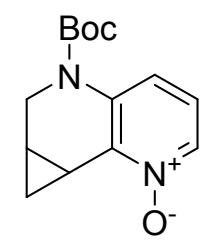

Tert-butyl 6,6a,7,7a-tetrahydro-5H-cyclopropa(c) \{1,5\}napthyridine-5-carboxylate (43.0 g, 174.6 $\mathrm{mmol}, 1.0$ eq.) was added to a solution of DCM $(300 \mathrm{~mL})$ in a 1-L three neck round bottom flask. To this m-CPBA $\left(41.4 \mathrm{~g}, 192.0 \mathrm{mmol}, 80 \%\right.$ purity, $1.1 \mathrm{eq}$.) was added at $0{ }^{\circ} \mathrm{C}$, and this was allowed to stir at $20^{\circ} \mathrm{C}$ for $12 \mathrm{~h}$. The reaction mixture was poured into $10 \% 15$ sodium sulfate solution $(600 \mathrm{~mL})$ and extracted with DCM $(500 \mathrm{~mL}, 200 \mathrm{~mL})$. The organic layers were combined, washed with brine $(300 \mathrm{~mL})$, dried over anhydrous sodium sulfate, and filtered and concentrated to dryness. The crude product was used in the next step without further purification. The title compound was obtained as a off white solid $(84 \mathrm{~g}$ crude from 2 reactions in parallel). ${ }^{1} \mathrm{HNMR}:\left(400 \mathrm{MHz}, \mathrm{CDCl}_{3}\right)$ ס: $8.10(\mathrm{~d}, \mathrm{~J}=6.8 \mathrm{~Hz}, 1 \mathrm{H}), 7.31(\mathrm{~d}, J=8.0 \mathrm{~Hz}, 1 \mathrm{H}), 6.97-$ $7.00(\mathrm{~m}, 1 \mathrm{H}), 4.56(\mathrm{~d}, J=13.2 \mathrm{~Hz}, 1 \mathrm{H}), 3.17-3.23(\mathrm{~m}, 1 \mathrm{H}), 2.95(\mathrm{~d}, J=13.2 \mathrm{~Hz}, 1 \mathrm{H}), 2.06-2.10$ $(\mathrm{m}, 1 \mathrm{H}), 1.49(\mathrm{~s}, 9 \mathrm{H}), 1.32-1.37(\mathrm{~m}, 1 \mathrm{H}), 0.89-0.93(\mathrm{~m}, 1 \mathrm{H})$.

Step f: tert-butyl-2-cyano-6,6a,7-7a-tetrahydro-5H-cyclopropan(c)\{1,5\}napthyridine-5carboxylate (16)<smiles>N#Cc1ccc2c(n1)C1CC1CN2C(=O)c1ccccc1</smiles>

5-(Tert-butoxycarbonyl)-6,6a,7,7a-tetrahydro-5H-cyclopropa(c) $\{1,5\}$ napthyridine-1-oxide (84.0 g, $320.2 \mathrm{mmol}, 1.0$ eq.) was added to a solution of $25 \mathrm{DCM}(420 \mathrm{~mL})$ in a 3-L three neck round bottom flask. To this ACN $(420 \mathrm{~mL})$ and TMSCN $(47.7 \mathrm{~g}, 480.4 \mathrm{mmol}, 60.1 \mathrm{~mL}, 1.5 \mathrm{eq}$.) were added, and this was allowed to stir $20^{\circ} \mathrm{C}$ for $10 \mathrm{~min}$. To this compound $9-1(43.1 \mathrm{~g}, 400.3 \mathrm{mmol}$, $36.8 \mathrm{~mL}, 1.25$ eq.) was added, and this was allowed to stir at $20^{\circ} \mathrm{C}$ for $12 \mathrm{~h}$. To this $10 \%$ potassium carbonate $(840 \mathrm{~mL}$ ) was added, and this was stirred for $20 \mathrm{~min}$. This was poured into water $(500 \mathrm{~mL})$. The aqueous phase was extracted with $\mathrm{DCM}(2 \times 500 \mathrm{~mL})$, washed with brine $(500 \mathrm{~mL})$, dried over anhydrous sodium sulfate and filtered and concentrated to dryness. MTBE $(300 \mathrm{~mL})$ was added, and this was stirred at $20^{\circ} \mathrm{C}$ for $30 \mathrm{~min}$, and the suspension was filtered. The residue was washed with MTBE $(100 \mathrm{~mL})$, and 5 the solid obtained was dried under vacuum. The title compound was obtained as a solid. MS ESI calcd. for $\mathrm{C}_{15} \mathrm{H}_{18} \mathrm{~N}_{3} \mathrm{O}_{2}[\mathrm{M}+\mathrm{H}]^{+}$ 272.1; found 272.1

Step g: tert-butyl 2-(1-aminocyclopropyl)-6,6a,7,7a-tetrahydro-5Hcyclopropa[c][1,5]naphthyridine-5-carboxylate 


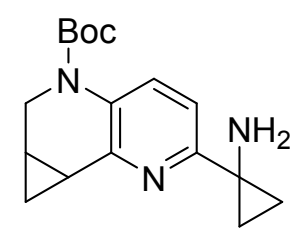

To a $3 \mathrm{~L}$ flask was added tert-butyl-2-cyano-6,6a,7-7a-tetrahydro-5Hcyclopropan(c) $\{1,5\}$ napthyridine-5-carboxylate $(40.1 \mathrm{~g}, 148 \mathrm{mmol})$. It was equipped with an overhead stirrer and pressure equalizing addition funnel along with a thermocouple probe. It was placed under nitrogen and charged with $800 \mathrm{~mL}$ of 2-methyl THF. It was cooled in a dry ice and acetone bath and then titanium isopropoxide $(88 \mathrm{~mL}, 296 \mathrm{mmol})$ was added while maintaining temperature below $-70{ }^{\circ} \mathrm{C}$. After addition $20 \mathrm{~mL}$ of 2-methyl THF was used to rinse the addition funnel and then ethylmagnesium bromide (3.4M in 2-MeTHF, $103 \mathrm{~mL}, 355 \mathrm{mmol}$ ) was added to the addition funnel and dropwise added to the reaction maintaining a temperature below $-70{ }^{\circ} \mathrm{C}$. Addition funnel was rinsed again with $20 \mathrm{~mL}$ of 2-methyl THF and then the mixture was allowed to slowly warm to room temperature while stirring for 12 more hours. When done, it was quenched carefully with $800 \mathrm{~mL}$ of brine, and then $100 \mathrm{~g}$ of Celite was added and it was filtered. The phases were separated, and the aqueous phase was extracted 2 more times with $500 \mathrm{~mL}$ of ethyl acetate. The organic layers were combined, dried with sodium sulfate, filtered and evaporated to afford the desired crude material which was used as is for the next step. MS ESI calcd. for $\mathrm{C}_{17} \mathrm{H}_{24} \mathrm{~N}_{3} \mathrm{O}_{2}[\mathrm{M}+\mathrm{H}]^{+}$302.2; found 302.1.

Step h: tert-butyl 2-(1-(4-fluorobenzamido)cyclopropyl)-6,6a,7,7a-tetrahydro-5Hcyclopropa[c][1,5]naphthyridine-5-carboxylate (17)

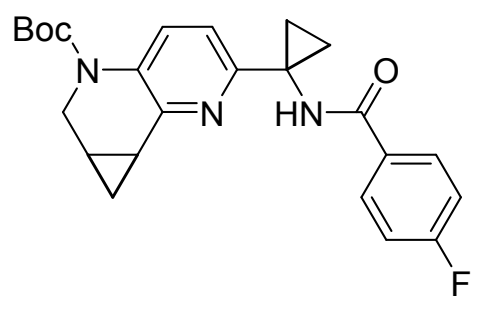

tert-butyl 2-(1-aminocyclopropyl)-6,6a,7,7a-tetrahydro-5H-cyclopropa[c][1,5]naphthyridine-5carboxylate $(50 \mathrm{~g}, 148 \mathrm{mmol})$ was added to a round bottom flask with $500 \mathrm{~mL}$ of DCM. Then triethylamine $(62 \mathrm{~mL}, 445 \mathrm{mmol}$ ) was added and it was cooled in an ice and water batch. After 15 minutes, 4-fluorobenzoyl chloride $(18.4 \mathrm{~mL}, 155 \mathrm{mmol})$ in $100 \mathrm{~mL}$ of DCM was added dropwise over 45 minutes via an addition funnel. When done, the reaction was quenched with $250 \mathrm{~mL}$ of saturated sodium bicarbonate and then the phases were separated and the aqueous layer was extracted $2 \times 200 \mathrm{~mL}$ of DCM. The organics were combined and dried with sodium sulfate, filtered, and evaporated in vacuo to afford the crude material. The desired material was isolated via silica gel column chromatography (hexanes and ethyl aceate as eluent). The fractions were evaporated, triturated with a small amount of DCM, and then solvent-exchanged with hexanes to form a thick white suspension. It was then filtered, and the white solid washed with hexanes and dried on the filter cake by pulling air through it overnight to afford the desired material (46 g, $73 \%$ over 2 steps). MS ESI calc'd for $\mathrm{C}_{24} \mathrm{H}_{27} \mathrm{FN}_{3} \mathrm{O}_{3}[\mathrm{M}+\mathrm{H}]^{+} 424.2$; found, 424.2 . 
step i: 4-fluoro-N-(1-(6,6a,7,7a-tetrahydro-5H-cyclopropa[c][1,5]naphthyridin-2yl)cyclopropyl)benzamide

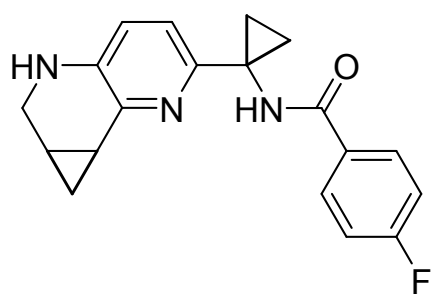

tert-butyl 2-(1-(4-fluorobenzamido)cyclopropyl)-6,6a,7,7a-tetrahydro-5Hcyclopropa[c][1,5]naphthyridine-5-carboxylate $(41.7 \mathrm{~g}, 99 \mathrm{mmol})$ was added to a round bottom flask. To this was added $418 \mathrm{~mL}$ of DCM and it was cooled to $-5^{\circ} \mathrm{C}$ in an ice/brine bath. TFA $(22.8 \mathrm{~mL}, 296 \mathrm{mmol}$ ) was added over 2 minutes and it was allowed to slowly warm to room temperature. Then TFA (100 $\mathrm{ml}, 1298 \mathrm{mmol})$ was added and it was stirred overnight at room temperature. When done by LCMS, it was concentrated on the rotovap. It was then stirred while adding $500 \mathrm{~mL}$ of saturated sodium bicarbonate. Then $500 \mathrm{~mL}$ of DCM was added and the aqueous layer was separated and extracted $2 \times 250 \mathrm{~mL}$ of DCM. The organics were combined, dried with sodium sulfate, filtered and evaporated in vacuo to afford the desired material. MS ESI calc'd for $\left.\mathrm{C}_{19} \mathrm{H}_{19} \mathrm{FN}_{3} \mathrm{O} \mathrm{M}+\mathrm{H}\right]^{+} 324.1$; found 324.2.

step j: 4-fluoro-N-(1-(5-(2-methylpyrimidin-4-yl)-6,6a,7,7a-tetrahydro-5Hcyclopropa[c][1,5]naphthyridin-2-yl)cyclopropyl)benzamide

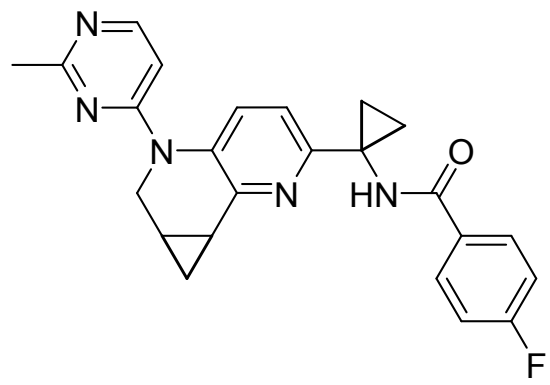

4-fluoro-N-(1-(6,6a,7,7a-tetrahydro-5H-cyclopropa[c][1,5]naphthyridin-2-

yl)cyclopropyl)benzamide ( $29 \mathrm{~g}, 228 \mathrm{mmol}$ ) was added to a 2 neck $500 \mathrm{~mL}$ RBF equipped with a relux condensor along with 4-chloro-2-methylpyrimidine $(29.3 \mathrm{~g}, 228 \mathrm{mmol})$ and paratoluenesulfonic acid monohydrate $(19.9 \mathrm{~g}, 104 \mathrm{mmol})$. The $290 \mathrm{~mL}$ of NMP was added and it was heated at $65^{\circ} \mathrm{C}$ overnight. It was then charged with an addition 26 grams of 4-chloro-2methylpyrimidine and heated to $75^{\circ} \mathrm{C}$ for 6 hours. It was then cooled to room temperature. It was then added to a beaker with $500 \mathrm{~mL}$ of water and stirred, before separating the organic layer. The organics were neutralized by addition of saturated sodium bicarbonate and $2 \mathrm{M}$ $\mathrm{NaOH}$. The aqueous layer was then separated and extracted with ethyl acetate. The combined organics were then concentrated to dryness. The crude material was then dissolved in $500 \mathrm{~mL}$ of ethyl acetate and extracted $2 \times 200 \mathrm{~mL}$ of $1 \mathrm{M} \mathrm{HCl}$. The aqueous phase was then washed $2 \mathrm{x}$ with $200 \mathrm{~mL}$ of ethyl acetate and then neutralized with the addition of $200 \mathrm{ml}$ of $2 \mathrm{M} \mathrm{NaOH}$. Then this aqueous layer was extracted $2 \times 300 \mathrm{~mL}$ of ethyl acetate. It was then concentrated to 
dryness and dry loaded onto silica gel before purifying via silica gel column chromatography with methanol and DCM as eluent. The fractions were combined and evaporated in vacou. Then they were dissolved in ethyl acetate and washed $3 \times 100 \mathrm{~mL}$ of water and $2 \times 100 \mathrm{~mL}$ brine. The organics were then dried with sodium sulfate, filtered, and evaporated in vacuo. It was then purified by SFC (OJ-H, $21 \times 250)$ using $\mathrm{MeOH}$ with a DMEA modifier. Peak 1 off the column was the desired compound 6 . Further evaporation and consecutive stirring and then concentration in DMC then MTBE then hexanes and ultimately n-heptane afforded a white solid that was collected by filtration and dried in a vacuum oven $\left(5.8 \mathrm{~g}, 15 \%\right.$ yield). ${ }^{1} \mathrm{H}$ NMR (600 MHz, DMSO-d $\left.d_{6}\right) \delta 9.28(\mathrm{~s}, 1 \mathrm{H}), 8.12(\mathrm{~d}, J=6.1 \mathrm{~Hz}, 1 \mathrm{H}), 8.02(\mathrm{dd}, J=8.7,5.5 \mathrm{~Hz}, 2 \mathrm{H}), 7.57$ (d, $J=8.4 \mathrm{~Hz}, 1 \mathrm{H}), 7.33(\mathrm{t}, J=8.8 \mathrm{~Hz}, 2 \mathrm{H}), 7.15(\mathrm{~d}, J=8.4 \mathrm{~Hz}, 1 \mathrm{H}), 6.64(\mathrm{~d}, J=6.1 \mathrm{~Hz}, 1 \mathrm{H}), 5.12$ $(\mathrm{d}, J=12.8 \mathrm{~Hz}, 1 \mathrm{H}), 2.93(\mathrm{~d}, J=12.7 \mathrm{~Hz}, 1 \mathrm{H}), 2.43(\mathrm{~s}, 3 \mathrm{H}), 2.20-2.05(\mathrm{~m}, 2 \mathrm{H}), 1.69-1.49(\mathrm{~m}$, $2 \mathrm{H}), 1.31-1.21(\mathrm{~m}, 2 \mathrm{H}), 1.05(\mathrm{td}, J=8.3,5.0 \mathrm{~Hz}, 1 \mathrm{H}), 0.55(\mathrm{q}, J=4.7 \mathrm{~Hz}, 1 \mathrm{H}) .{ }^{13} \mathrm{C}$ NMR $(126$ MHz, DMSO- $\left.d_{6}\right) \delta 166.87,166.07,164.01(\mathrm{~d}, J=248.6 \mathrm{~Hz}), 161.20,157.07,156.45,152.52$, 130.86, 130.78 (d, $J=2.8 \mathrm{~Hz}), 130.07$ (d, $J=9.2 \mathrm{~Hz}), 128.84,116.11,115.21$ (d, $J=21.6 \mathrm{~Hz})$, $101.77,40.11,36.00,25.86,20.73,18.60,16.98,8.63$.

LRMS (ESI) calc'd for $\mathrm{C}_{24} \mathrm{H}_{23} \mathrm{FN}_{5} \mathrm{O}[\mathrm{M}+\mathrm{H}]^{+}$, 416.2; found, 416.3. HRMS (El) calc'd for $\mathrm{C}_{24} \mathrm{H}_{23} \mathrm{FN}_{5} \mathrm{O}[\mathrm{M}+\mathrm{H}]^{+}$, 416.1887; found, 416.1888.

\section{In Vivo PK Protocol and Animal Care Statements}

Reference standard of the analyte was synthesized at Merck Research Laboratories and a $10 \mathrm{mM}$ stock solution was made by dissolving a suitable quantity of the standard compound in dimethyl sulfoxide (DMSO). Standard working solutions at 1 and $0.05 \mathrm{mM}$ were prepared by diluting suitable amounts of the stock solution $(10 \mathrm{mM})$ with DMSO for the calibration standards (STD) and quality control (QC) samples preparation. Calibration standards and quality control samples were prepared by dispensing different volumes (ranging from 0.02 to $500 \mathrm{~nL}$ ) of the standard working solutions using the HP D300 Digital Dispenser. Compounds were dosed as indicated in Table 2. Studies were conducted either at Charles River Laboratories or at WuXi AppTec. At WuXi, Adult Male Wistar Han rat weighing 200-300 g were purchased from Beijing Vital River Laboratory Animal Technology Co., Ltd, Beijing, China. All the animals were housed in the AAALAC accredited barrier animal facility at $20-260 \mathrm{C}, 40 \%-70 \%$ humidity and $12 \mathrm{~h}$ light/dark cycles. All the experiments were approved by Institutional Animal Care and Use Committee (IACUC) of WuXi AppTec. At Charles River Laboratories, Male Wistar Han rats, $\mathrm{Crl}: W I(H a n), 6-8$ weeks old, weighing 225- $250 \mathrm{~g}$ were purchased from Charles River Laboratories, International, Inc., Kingston, New York, USA. All the animals were housed in the AAALAC accredited vivarium at $20-260 \mathrm{C}, 30 \%-70 \%$ humidity and $12 \mathrm{~h}$ light/dark cycles. All the experiments were approved by Institutional Animal Care and Use Committee (IACUC) of Charles River Massachusetts. Unknown samples obtained from dosed animals, calibration standards, and quality control samples were prepared for analysis employing a single step protein precipitation technique by adding $200 \mu \mathrm{L}$ of internal standard (IS) crashing solvent to 50 $\mu \mathrm{L}$ aliquots of individual samples. The internal standard solution is prepared by diluting $1 \mathrm{~mL}$ ampoule of Cerilliant IS MIX (Diclofenac $200 \mu \mathrm{M}$, Labetalol $200 \mu \mathrm{M}$, and Imipramine $200 \mu \mathrm{M}$ ) in $1 \mathrm{~L}$ of acetonitrile. Samples were mixed by vortexing for homogeneity for 2 min and centrifuged at $3500 \mathrm{rpm}$ for $5 \mathrm{~min}$. The supernatant $(200 \mu \mathrm{L})$ was transferred into a 96 -well plate and 
injected into the LC-MS/MS for analysis. Chromatography was performed on a Waters Acquity HSS T3 $(2.1 \mathrm{~mm} \times 50 \mathrm{~mm}, 1.8 \mu \mathrm{m})$ column at room temperature with an injection volume of 5 $\mu \mathrm{L}$. The mobile phase consisting of a solvent $A(0.1 \%$ formic acid in water) and solvent $\mathrm{B}(0.1 \%$ formic acid in acetonitrile) was delivered at a flow rate of $750 \mu \mathrm{L} / \mathrm{min}$. The $\mathrm{LC}$ gradient started from $95 / 5(\mathrm{~A} / \mathrm{B})$ and changed to $5 / 95$ (A/B) from 0.25 to $1.75 \mathrm{~min}$ (ramp) and remaining constant to this ratio for $0.42 \mathrm{~min}$ (step). The gradient decreased to $95 / 5(A / B)$ at $2.17 \mathrm{~min}$ (step) remaining constant to this ratio for $1.0 \mathrm{~min}$. Detection was carried out using a triple quadrupole tandem mass spectrometer (API 6500, Applied Biosystems) equipped with an electrospray interface $(\mathrm{ESI})$. lons were created in the positive ion mode setting the sprayer voltage at $5.0 \mathrm{kV}$ and the ion source temperature at $500^{\circ} \mathrm{C}$. The common parameters and the nitrogen flow values for nebulizer gas (Gas 1), auxiliary gas (Gas 2), curtain gas and the gas for collision-activated dissociation (CAD) were set at 60,60, 35, and 5, respectively. The Analyst 1.6.2 software (Applied Biosystems) was used to control the MS-MS system and MultiQuant 3.0.1 for data analyses.

\section{Crystallography}

Human IDO1 was expressed in $E$. coli and purified by Ni affinity chromatography followed by a size exclusion chromatography step. Crystals of human IDO1 in complex with compound $\mathbf{5}$ were grown using hanging drop vapor diffusion method at $293 \mathrm{~K}$ by mixing protein solution $(25 \mathrm{mg} / \mathrm{ml}$ in $25 \mathrm{mM}$ MES pH 6.5, $150 \mathrm{mM} \mathrm{KCl}$ preincubated with $20 \mathrm{mM}$ ligand) with reservoir solution $(0.1 \mathrm{mM}$ Tris $\mathrm{pH} 8.0,20 \%(\mathrm{w} / \mathrm{v}) \mathrm{PEG} 6000)$ in a 1:1 ratio. To obtain high resolution diffraction data of human IDO1 in complex with $\mathbf{5}$, crystals were optimized and flash cooled using the free mounting system ${ }^{\mathrm{TM}}$ (1). Diffraction data were collected at $100 \mathrm{~K}$ at the Diamond Light Source (DLS, Oxford, UK) and processed using XDS and XSCALE (2). Structures were solved using Phaser (3) and a previously solved hIDO structure as search model. Subsequent model building and refinement was performed with COOT and REFMAC $(4,5)$.

1. Kiefersauer, R. et al. (2000) J. Appl. Cryst. 33:1223-1230.

2. Kabsch, W. (2010) Acta Cryst. D66:125-132.

3. McCoy, A.J. et al. (2007) J. Appl. Cryst. 40:658-674.

4. Emsley, P. et al. (2010) Acta Cryst. D66:486-501.

5. Murshudov, G.N. (1997) Acta Cryst. D53:240-255.

Data Collection and Refinement Statistics*

\begin{tabular}{|c|c|}
\hline & ID01 complex with 4 \\
\hline PDB code & $6 \times 5 Y$ \\
\hline \multicolumn{2}{|c|}{ Data Collection and Processing } \\
\hline X-ray source & SLS X10SA \\
\hline Detector & PILATUS 6M \\
\hline
\end{tabular}




\begin{tabular}{|l|l|} 
Wavelength $(\AA)$ & 0.9999 \\
\hline Temperature $(\mathrm{K})$ & 100 \\
\hline Space group & $P 2_{2} 2_{1}{ }_{1}$ \\
\hline Cell: a, b, c $(\AA)$ & $84.94,92.16,130.13$ \\
\hline Resolution $(\AA)^{*}$ & $75-2.65(2.90-2.65)$ \\
\hline Unique Reflections & $29971(6969)$ \\
\hline Multiplicity & $3.3(3.2)$ \\
\hline Completeness (\%) & $98.7(98.6)$ \\
\hline$R_{\text {sym }}(\%)$ & $3.9(43.5)$ \\
\hline$R_{\text {meas }}(\%)$ & $4.7(52.1)$ \\
\hline Mean(I)/sd & $19.57(2.79)$ \\
\hline CC(1/2) & $0.999(0.869)$ \\
\hline Refinement & $75-2.65$ \\
\hline Resolution $(\AA)$ & $29141 / 830$ \\
\hline No. reflections (working / test) & $24.0 / 27.2$ \\
\hline$R_{\text {cryst }} / R_{\text {free }}(\%)$ & \\
\hline Total No. Atoms & 5941 \\
\hline Protein & 22 \\
\hline Water & 60 \\
\hline Ligand & \\
\hline Deviation from Ideality & 0.011 \\
\hline Bond lengths $(\AA)$ & 1.31 \\
\hline Bond Angles $\left({ }^{\circ}\right)$ & \\
\hline Ramachandran Analysis & 92.4 \\
\hline Most favored $(\%)$ & 7.4 \\
\hline Additionally allowed $(\%)$ & 0.2 \\
\hline Generously allowed $(\%)$ & 0.0 \\
\hline Disallowed (\%) &
\end{tabular}

* Values in parentheses indicate highest resolution shell. The structure was obtained commercially from Proteros Biostructures $\mathrm{GmbH}$ (Martinsried, Germany).

\section{Prediction of Human Pharmacokinetic Parameters and Efficacious Dose}

Preclinical concentration-time data from rat and dog was fit to a two compartment pharmacokinetic model (WNL5 Classic Model 6.3; Phoenix 64 (Build 6.3.0.395)) to obtain the mean, standard error and correlation matrix of the clearance and volume of distribution in each of these species. As compounds were assumed to be cleared primarily by CYP-mediated oxidative metabolism in rat and dog (data not shown), the human clearance and volume of distribution parameters were predicted using the geomean of the rat and dog single species allometric scaling with fixed allometric exponents of 0.75 and 1 , respectively. If oral PK data was not available, the prediction of oral absorption was achieved using the FaFgFh method, 
where Fa was estimated using a permeability limited model, Fg was fixed to 0.5, and Fh was set to the ratio of the predicted human blood clearance and human hepatic blood flow. For compounds with available oral PK data, the FaFg method was used where Fa* Fg was determined from the preclinical species and Fh was set to the ratio of the predicted human blood clearance and human hepatic blood flow. Human pharmacokinetics were assumed to follow the two compartment model profile observed in preclinical species.

Steady-state trough coverage of the projected human $\mathrm{IC}_{75}$ for IDO1 from in vitro whole blood assays following a simulated once daily oral administration (QD) to steady state was assumed to be the required efficacious dose. The human dose was predicted using an internal webbased application employing $\mathrm{R}$ script which enables incorporation and visualization of the impact of experimental uncertainty on the predicted dose and PK. Uncertainty estimates were obtained using Monte Carlo simulation (1000 simulations) and used to generate the human concentration-time profile while sampling from these parameter distributions, resulting in a median predicted profile where Ctrough $=I D O 1 I_{75}$ at steady state with associated confidence intervals.

\section{In vivo PK/PD studies}

All animal experimental procedures were approved by Merck's Institutional Animal Care and Use Committee (IACUC) prior to conduct. During the study, the care and use of animals was conducted in accordance with the regulations of the Association for Assessment and Accreditation of Laboratory Animal Care (AAALAC). Female CD-1 Nude mice, 6-8 weeks of age, were purchased from Charles River Laboratories (Wilmington, MA) and were maintained in a pathogen-free environment. All animals received food and water ad libitum. Animals were inoculated subcutaneously in the lower right flank with 1.5x10E6 CT26 overexpressing hIDO1 (hIDO1-CT26, a murine cell line generated in house to constitutively express the human IDO1 protein). Resultant tumors were grown to approximately $150 \mathrm{~mm} 3$ in size before initiating treatment. Mice were randomized to treatment groups (12 mice/group) and treated by oral gavage with a single dose of Compound 4 (3 mg/kg), or vehicle (10\% Tween-80). $2 \mathrm{~h}, 4 \mathrm{~h}, 8 \mathrm{~h}$, and $16 \mathrm{~h}$, following treatment, animals were euthanized by $\mathrm{CO} 2$ asphyxiation, whole blood was collected by cardiac puncture, and tumors were resected. Kynurenine and Compound 4 were measured in plasma and tumors by mass spectrometry.

\section{Determination of absolute stereochemistry of compounds 5 and 6 using NMR and VCD experiments}

\section{NMR Spectroscopy}


NMR data were acquired to confirm relative stereoconfigurations. One- and two-dimensional NMR spectra were recorded at room temperature $(298 \mathrm{~K})$ for ca. $0.2 \mathrm{mg} / \mathrm{mL}$ samples dissolved in deuterated chloroform with $0.03 \% \mathrm{v} / \mathrm{v}$ tetramethylsilane (TMS) using a $600 \mathrm{MHz}$ Bruker AVIII HD spectrometer equipped with a triple resonance $(\mathrm{HCN})$ helium cryoprobe. All chemical shifts were referenced versus the TMS signal at $0.00 \mathrm{ppm}$. COSY, ${ }^{13} \mathrm{C}$ multiplicity-edited HSQC, ${ }^{13} \mathrm{C}$ HMBC $\left(8 \mathrm{~Hz} J_{\text {opt }}\right.$ ), and ${ }^{15} \mathrm{~N} \mathrm{HMBC}\left(5 \mathrm{~Hz} J_{\mathrm{opt}}\right)$ spectra were acquired to assign the proton and carbon signals. Dipolar couplings from the NOESY (300 ms mixing time) spectra were used to verify the relative stereoconfigurations.

\section{$\underline{\text { VCD Measurements and Calculations }}$}

Samples were dissolved in deuterated chloroform at approximately $50 \mathrm{mg} / \mathrm{mL}$, and all experiments were performed using a $0.20-\mathrm{mm}$ path length cell with $\mathrm{BaF}_{2}$ windows. The IR and VCD spectra were recorded using a Chiral $R^{T M}$ VCD spectrometer equipped with the Dual PEM accessory (BioTools, Jupiter, $\mathrm{FL}$ ) allowing for a spectral resolution of $4 \mathrm{~cm}^{-1}$. A dry $\mathrm{N}_{2}$ purge was used to eliminate water from the instrument. Data were acquired using spectral averaging over approximately 7 hours. The background spectrum of the solvent was subtracted from the averaged sample spectrum.

The general approach for VCD assignment, including explicit details of the computational workflow, have been published previously. ${ }^{1,2}$ In summary, conformers of each structure were geometry optimized at the B3LYP-D3/6-31G $(d, p)$ level, and stationary points were confirmed by frequency calculations. -11 $^{-11}$ All calculations were performed using Gaussian '16.12 Frequency calculations output the IR and VCD spectra. ${ }^{13}$ Frequencies were scaled by a value of 0.98 , but owing to the secondary scaling and shifting of the calculated VCD and IR spectra in comparison to the experimental spectra, this initial scaling was, to some extent, arbitrary.

Output conformers were ranked according to DFT energy, and a clustering was performed to remove duplicates based on electronic energies within 0.01 a.u. Boltzmann distributions were calculated based on the in vacuu free energies. 


\section{Relative Stereochemistry Determination of Compound 6 by NMR Spectroscopy}

The relative stereochemistry was determined by the following set of NOEs from the NOESY NMR spectrum.

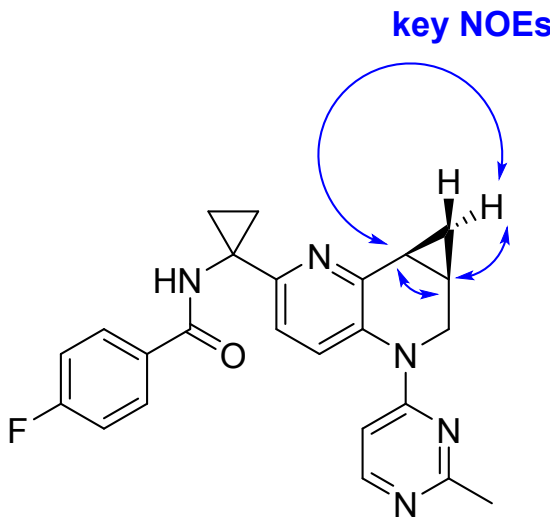

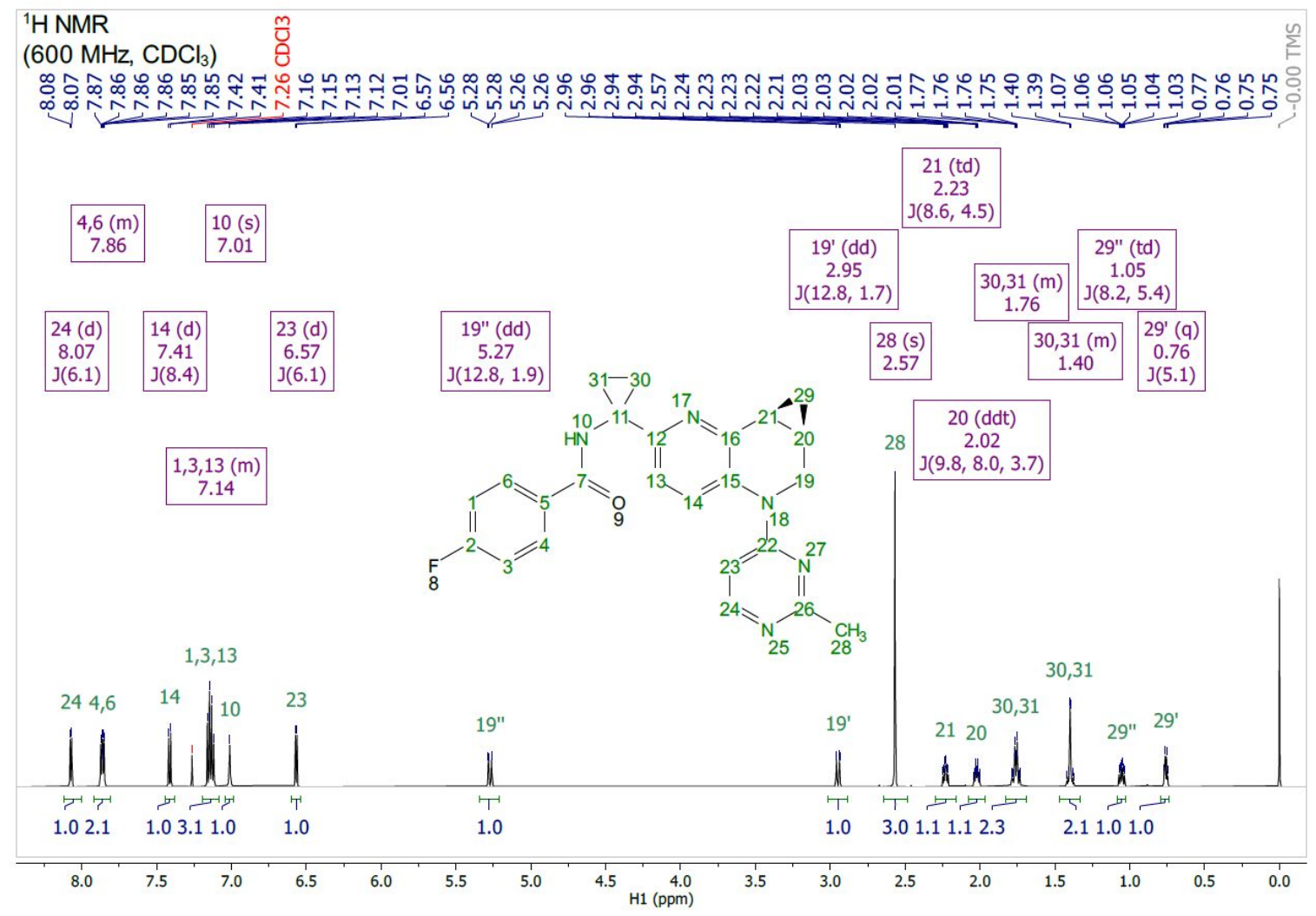




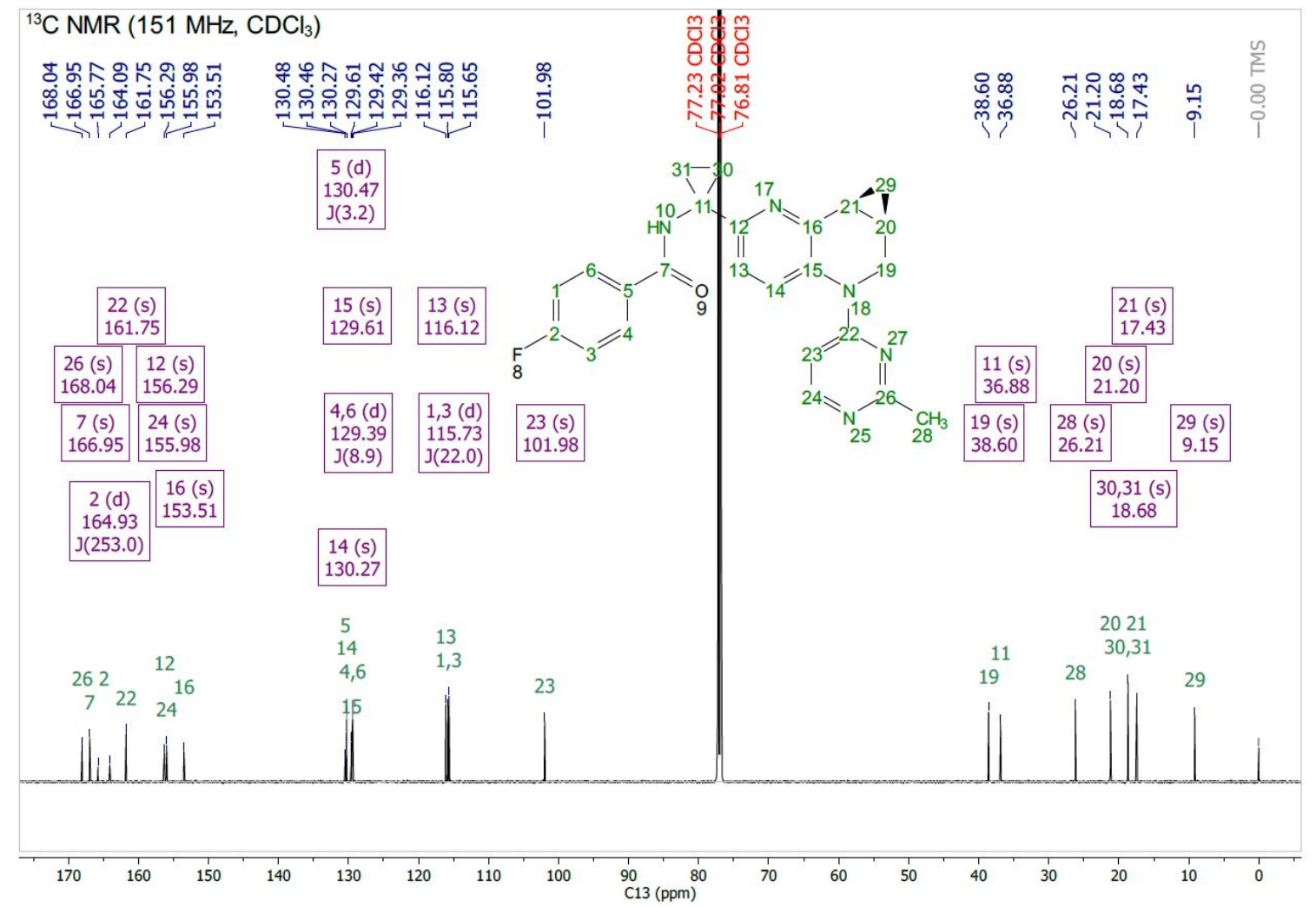

${ }^{1} \mathrm{H} /{ }^{1} \mathrm{H}$ COSY NMR $\left(600 / 600 \mathrm{MHz}, \mathrm{CDCl}_{3}\right)$

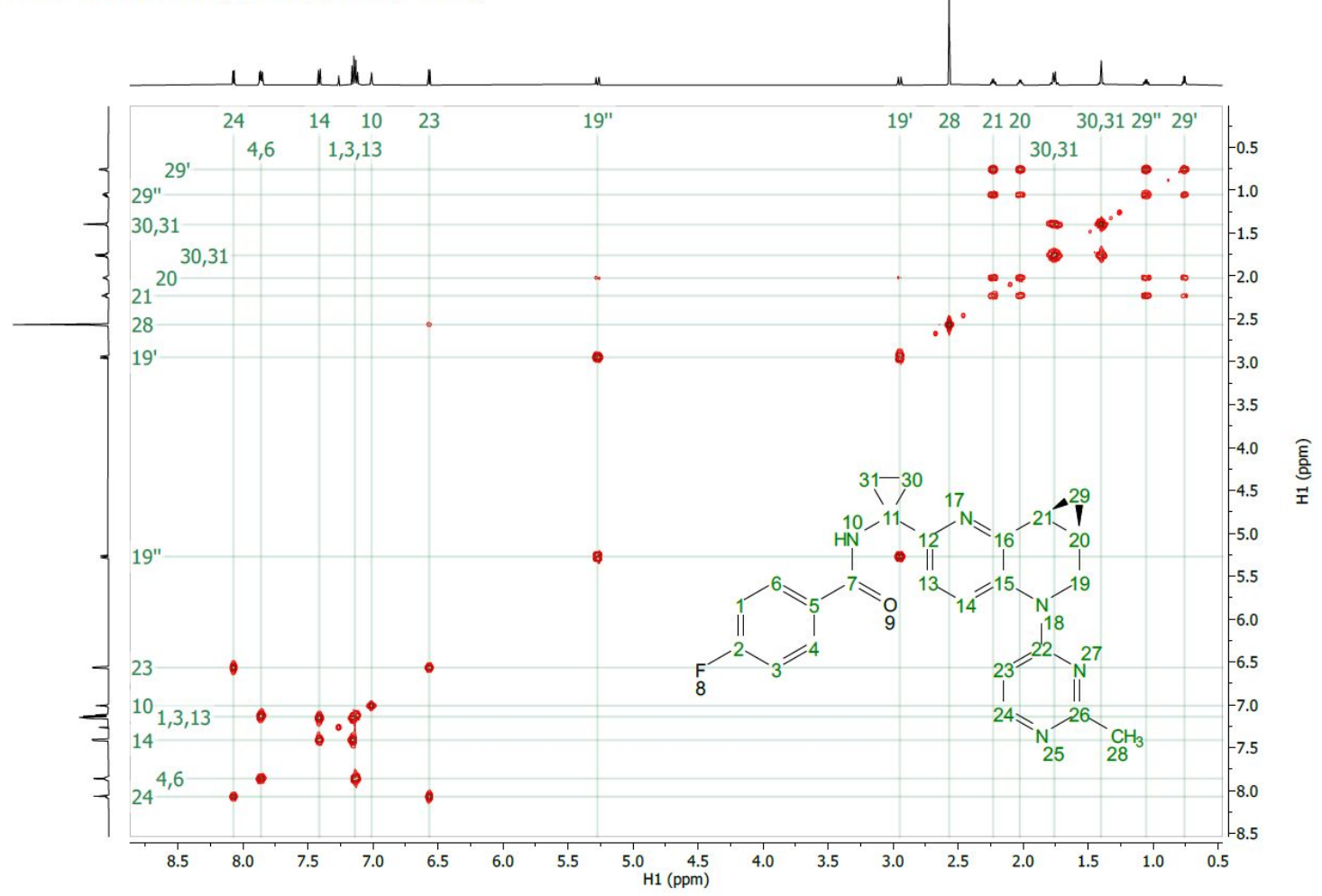


${ }^{1} \mathrm{H} /{ }^{13} \mathrm{C} \mathrm{HSQC} \mathrm{NMR}\left(600 / 151 \mathrm{MHz}, \mathrm{CDCl}_{3}\right)$

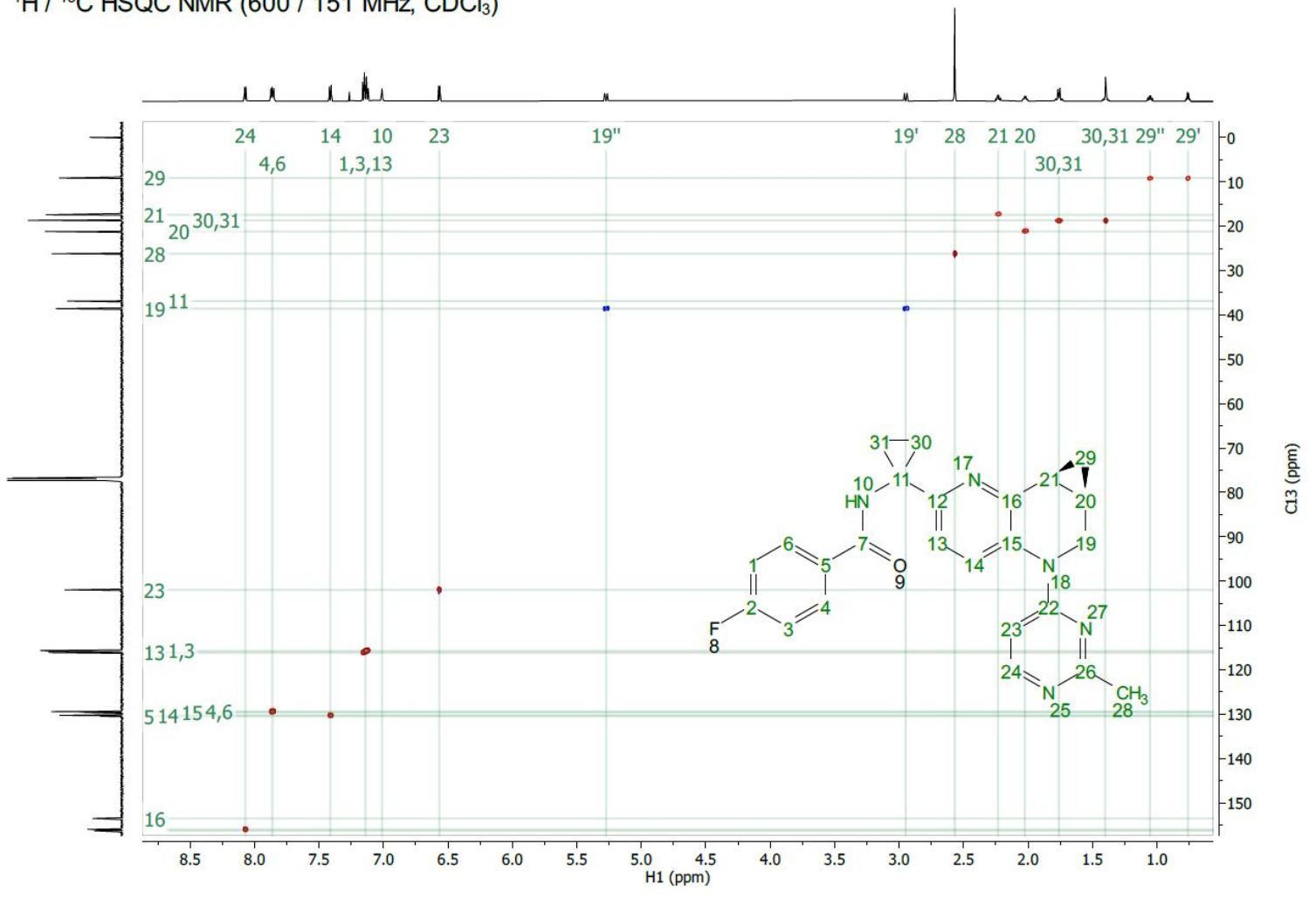

${ }^{1} \mathrm{H} /{ }^{13} \mathrm{C} \mathrm{HMBC} \mathrm{NMR}\left(600 / 151 \mathrm{MHz}, \mathrm{CDCl}_{3}\right)$

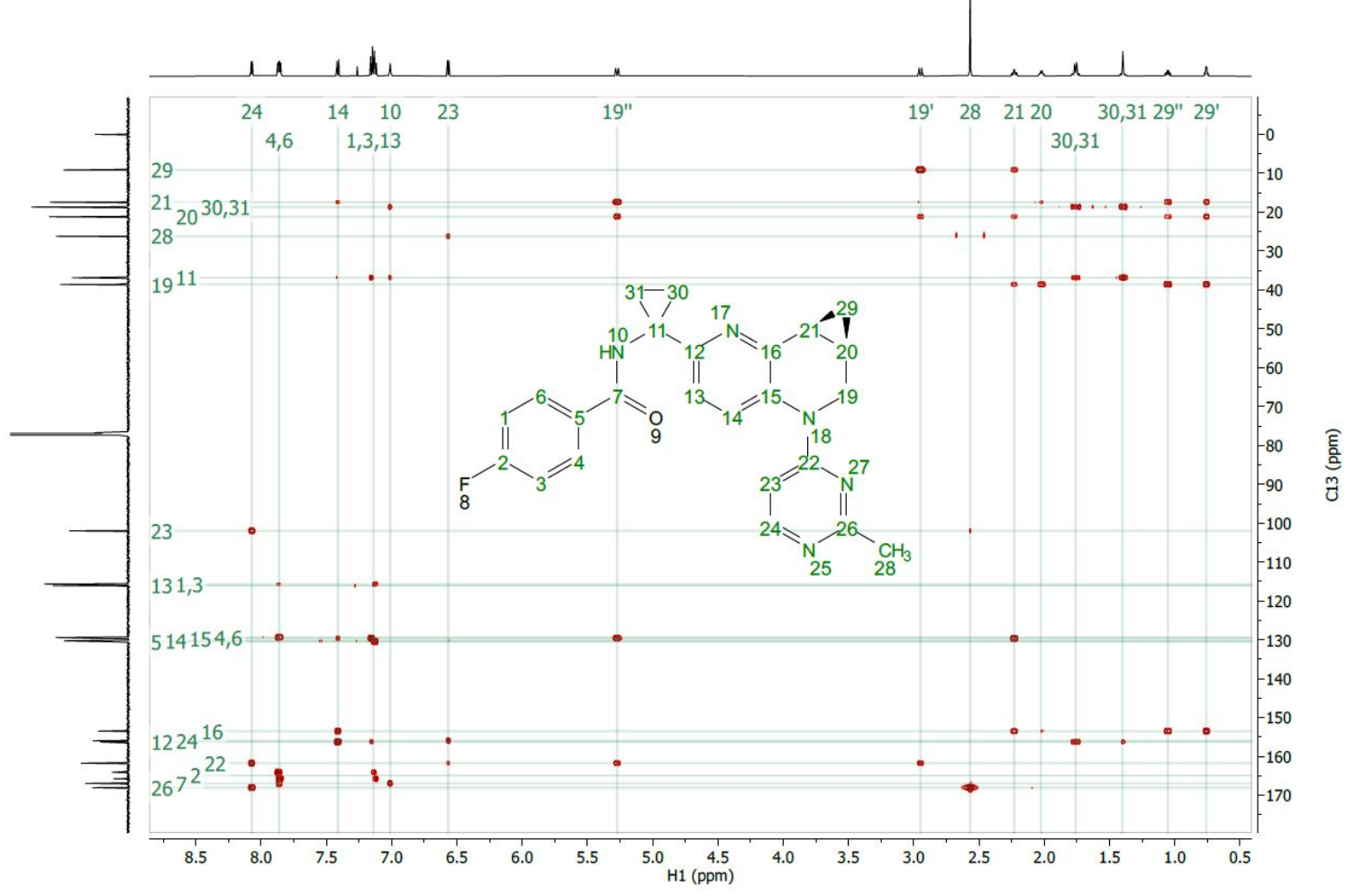


${ }^{1} \mathrm{H} /{ }^{15} \mathrm{~N} \mathrm{HMBC}$ NMR $\left(600 / 61 \mathrm{MHz}, \mathrm{CDCl}_{3}\right)$

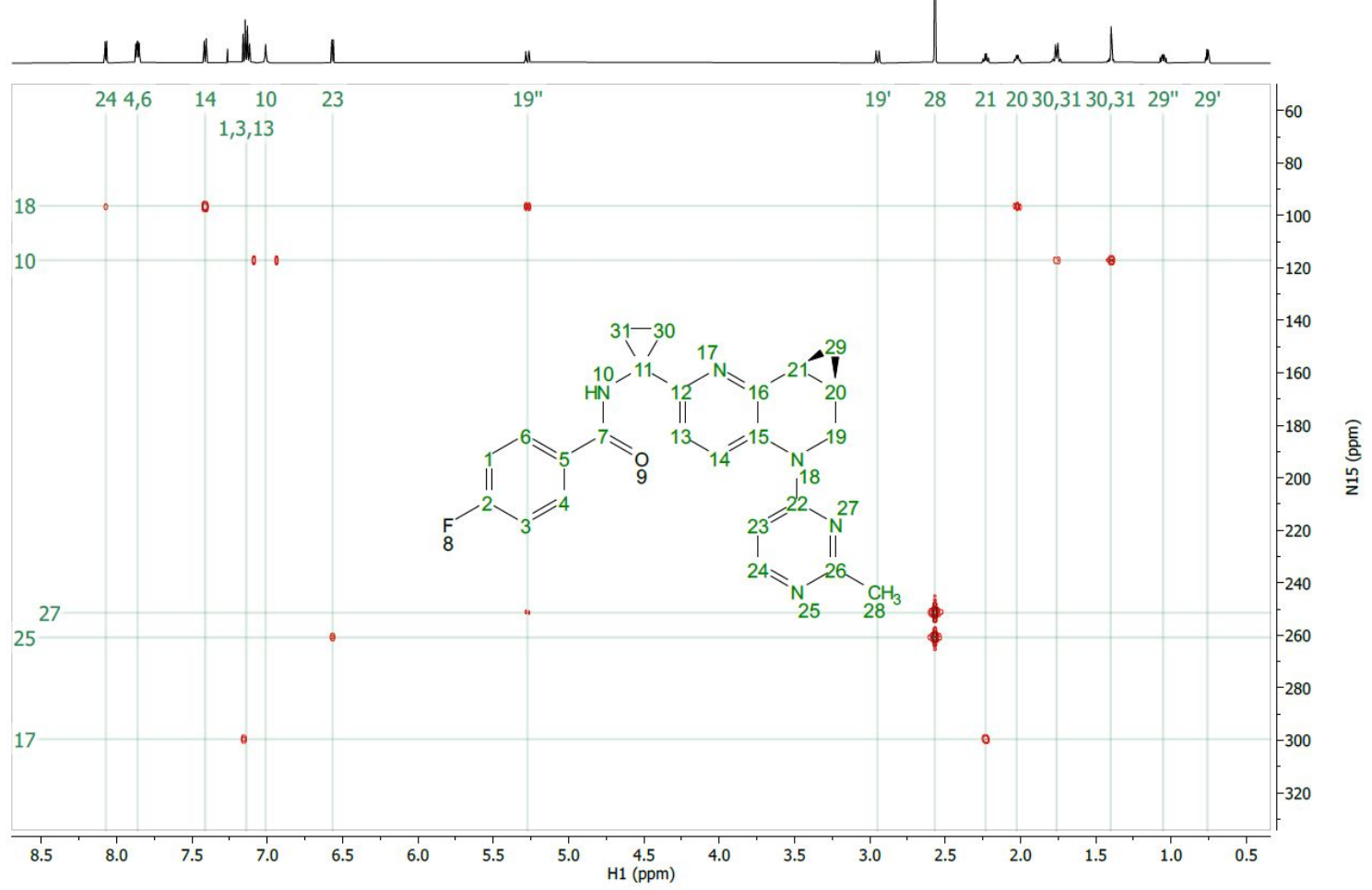

${ }^{1} \mathrm{H} /{ }^{1} \mathrm{H}$ NOESY NMR $\left(600 / 600 \mathrm{MHz}, \mathrm{CDCl}_{3}\right)$

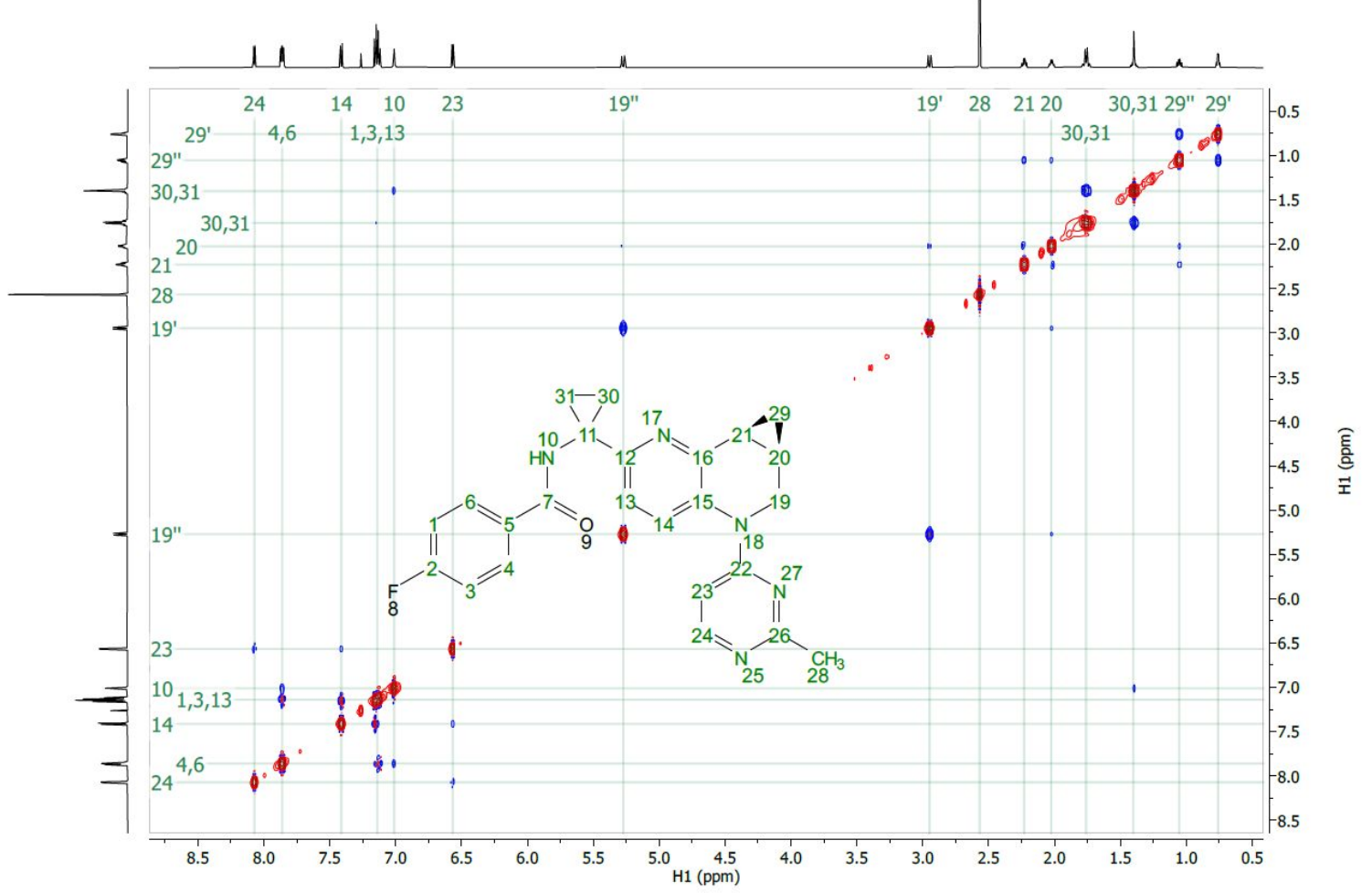




\section{DFT Calculation Results for compound 6}

The following is the calculated Boltzmann distribution at the B3LYP-D3/6-31G(d,p) level of theory showing low energy conformers. The cartesian coordinates for the energy minimized structures of the lowest 6 energy conformers are provided.

\begin{tabular}{|c|c|c|}
\hline Conformer & $\begin{array}{c}\text { Relative Energy } \\
(\mathrm{kcal} / \mathrm{mol})\end{array}$ & $\begin{array}{c}\text { Boltzmann } \\
\text { Population }\end{array}$ \\
\hline 1 & 0.726 & 6.85 \\
\hline 2 & 0.772 & 6.34 \\
\hline 3 & 0.000 & 23.09 \\
\hline 4 & 0.104 & 19.57 \\
\hline 5 & 0.140 & 18.42 \\
\hline 6 & 0.246 & 15.40 \\
\hline 7 & 2.112 & 0.66 \\
\hline 8 & 1.862 & 1.01 \\
\hline 9 & 1.882 & 0.97 \\
\hline 10 & 1.798 & 1.12 \\
\hline 11 & 2.432 & 0.38 \\
\hline 12 & 2.252 & 0.52 \\
\hline 13 & 3.652 & 0.05 \\
\hline 14 & 2.518 & 0.33 \\
\hline 15 & 3.686 & 0.05 \\
\hline 16 & 3.706 & 0.04 \\
\hline 17 & 1.916 & 0.92 \\
\hline 18 & 1.818 & 1.08 \\
\hline 19 & 3.128 & 0.12 \\
\hline 20 & 3.158 & 0.11 \\
\hline & & 96.8 \\
\hline
\end{tabular}




\section{Conformer \#1}

Rel. Energy $=0.726 \mathrm{kcal} / \mathrm{mol}$

$\begin{array}{llll}1 \mathrm{C} 1 & -5.0661 & 2.3037 & 0.7015\end{array}$

$\begin{array}{llll}2 \mathrm{C} 2 & -6.4202 & 2.2106 & 0.3997\end{array}$

$\begin{array}{lllll}3 \mathrm{C} 3 & -7.0104 & 1.0135 & 0.0071\end{array}$

$\begin{array}{lllll}4 \mathrm{C} 4 & -6.2112 & -0.1213 & -0.0904\end{array}$

$\begin{array}{lllll}5 \mathrm{C} 5 & -4.8387 & -0.0603 & 0.1866\end{array}$

$\begin{array}{llll}6 \mathrm{C6} & -4.2780 & 1.1595 & 0.5934\end{array}$

$\begin{array}{lllll}7 \mathrm{C7} & -4.0534 & -1.3379 & 0.0569\end{array}$

$\begin{array}{llll}8 \text { F8 } & -7.1866 & 3.3156 & 0.4996\end{array}$

$\begin{array}{lllll}909 & -4.6187 & -2.4349 & 0.0718\end{array}$

$10 \mathrm{~N} 10 \quad-2.7116 \quad-1.1820 \quad-0.0813$

11 C11 $-1.7192 \quad-2.2186 \quad-0.1839$

12 C12 $-0.3487 \quad-1.6166 \quad-0.3125$

$\begin{array}{lllll}13 \mathrm{C} 13 & 0.8168 & -2.3937 & -0.3993\end{array}$

$\begin{array}{lllll}14 \mathrm{C} 14 & 2.0425 & -1.7557 & -0.5275\end{array}$

$\begin{array}{llll}15 \mathrm{C} 15 & 2.0972 & -0.3580 & -0.5307\end{array}$

$\begin{array}{lllll}16 \mathrm{C} 16 & 0.8827 & 0.3507 & -0.4507\end{array}$

17 N17 $\quad-0.2970 \quad-0.2768 \quad-0.3544$

$\begin{array}{lllll}18 \mathrm{~N} 18 & 3.3001 & 0.3690 & -0.6979\end{array}$

19 C19 $3.2121 \quad 1.5436 \quad-1.5809$

$\begin{array}{lllll}20 & \mathrm{C} 20 & 2.1100 & 2.4844 & -1.1228\end{array}$

$\begin{array}{lllll}21 \text { C21 } & 0.8750 & 1.8301 & -0.5259\end{array}$

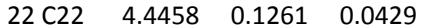

$\begin{array}{lllll}23 \mathrm{C} 23 & 4.4620 & -0.7303 & 1.1678\end{array}$

$\begin{array}{llll}24 \mathrm{C} 24 & 5.6770 & -0.8716 & 1.8122\end{array}$

$\begin{array}{lllll}25 \mathrm{~N} 25 & 6.8060 & -0.2473 & 1.4329\end{array}$

$\begin{array}{lllll}26 \mathrm{C} 26 & 6.6806 & 0.5590 & 0.3712\end{array}$

27 N27 $5.5603 \quad 0.7692 \quad-0.3359$

$\begin{array}{lllll}28 \mathrm{C} 28 & 7.9056 & 1.3037 & -0.0878\end{array}$

$\begin{array}{lllll}29 & \mathrm{C} 29 & 1.8315 & 2.6492 & 0.3385\end{array}$

$\begin{array}{lllll}30 \text { C30 } & -2.0083 & -3.5215 & -0.9200\end{array}$

$\begin{array}{llll}31 \text { C31 } & -1.8725 & -3.5250 & 0.5782\end{array}$

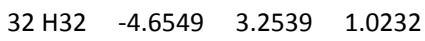

$\begin{array}{lllll}33 & \text { H33 } & -8.0724 & 0.9879 & -0.2104\end{array}$

34 H34 $-6.6327 \quad-1.0780 \quad-0.3784$

$\begin{array}{llll}35 \mathrm{H} 35 & -3.2272 & 1.2225 & 0.8599\end{array}$

36 H36 $-2.3065 \quad-0.2622 \quad-0.2136$

$\begin{array}{lllll}37 \text { H37 } & 0.7700 & -3.4765 & -0.3901\end{array}$

$38 \mathrm{H} 38 \quad 2.9576 \quad-2.3300 \quad-0.6270$

39 H39 $4.1867 \quad 2.0294 \quad-1.5698$

$40 \mathrm{H} 40 \quad 3.0070 \quad 1.2046 \quad-2.6042$

41 H41 $1.9509 \quad 3.3404 \quad-1.7743$

$42 \mathrm{H} 42 \quad-0.1016 \quad 2.2573 \quad-0.7282$

$\begin{array}{lllll}43 \mathrm{H} 43 & 3.5745 & -1.2315 & 1.5295\end{array}$

$44 \mathrm{H} 44 \quad 5.7552 \quad-1.5125 \quad 2.6888$

$45 \mathrm{H} 45 \quad 8.1409 \quad 1.0419-1.1245$

$\begin{array}{lllll}46 \mathrm{H} 46 & 7.7221 & 2.3829 & -0.0639\end{array}$

$\begin{array}{llll}47 \mathrm{H} 47 & 8.7560 & 1.0641 & 0.5508\end{array}$

$\begin{array}{lllll}48 \mathrm{H} 48 & 2.4538 & 2.1136 & 1.0488\end{array}$

$\begin{array}{llll}49 \mathrm{H} 49 & 1.4682 & 3.6093 & 0.6901\end{array}$

50 H50 $\quad-3.0126 \quad-3.6337 \quad-1.3088$

$\begin{array}{lllll}51 \text { H51 } & -1.2123 & -3.9289 & -1.5362\end{array}$

$\begin{array}{llll}52 \mathrm{H} 52 & -0.9800 & -3.9365 & 1.0402\end{array}$

$\begin{array}{llll}53 \mathrm{H} 53 & -2.7898 & -3.6431 & 1.1415\end{array}$

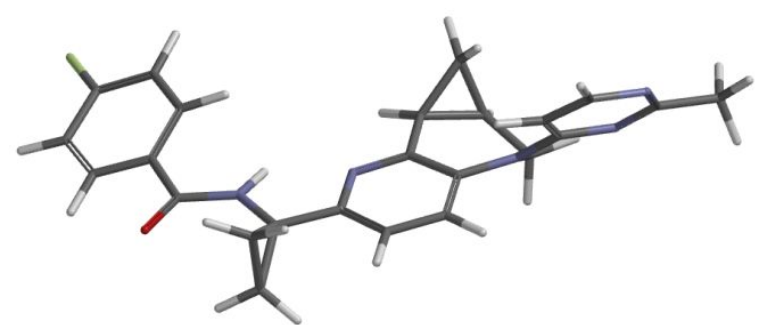

Boltzmann Population $=6.85 \%$ 


\section{Conformer \#2}

Rel. Energy $=0.772 \mathrm{kcal} / \mathrm{mol}$

$\begin{array}{llll}1 \mathrm{C} 1 & -5.2021 & 2.2966 & -0.2155\end{array}$

$\begin{array}{llll}2 \text { C2 } & -6.4652 & 2.1650 & 0.3508\end{array}$

$\begin{array}{lllll}3 \mathrm{C} 3 & -6.9526 & 0.9404 & 0.7963\end{array}$

$\begin{array}{lllll}4 \mathrm{C} 4 & -6.1407 & -0.1828 & 0.6735\end{array}$

$\begin{array}{lllll}5 \text { C5 } & -4.8542 & -0.0841 & 0.1262\end{array}$

$\begin{array}{llll}6 C 6 & -4.3989 & 1.1632 & -0.3260\end{array}$

$\begin{array}{llll}7 \mathrm{C} 7 & -4.0484 & -1.3518 & 0.0307\end{array}$

$\begin{array}{llll}8 \text { F8 } & -7.2453 & 3.2592 & 0.4629\end{array}$

$\begin{array}{lllll}909 & -4.5961 & -2.4569 & 0.0770\end{array}$

$\begin{array}{lllll}10 \mathrm{~N} 10 & -2.7077 & -1.1789 & -0.0988\end{array}$

$\begin{array}{llll}11 \text { C11 } & -1.7077 & -2.2021 & -0.2507\end{array}$

$\begin{array}{llll}12 \mathrm{C} 12 & -0.3430 & -1.5844 & -0.3659\end{array}$

$\begin{array}{llll}13 \mathrm{C} 13 & 0.8208 & -2.3456 & -0.5557\end{array}$

$\begin{array}{llll}14 \mathrm{C} 14 & 2.0425 & -1.6941 & -0.6508\end{array}$

$\begin{array}{llll}15 \mathrm{C} 15 & 2.0960 & -0.3028 & -0.5173\end{array}$

$\begin{array}{llll}16 \mathrm{C} 16 & 0.8836 & 0.3905 & -0.3361\end{array}$

$\begin{array}{llll}17 \mathrm{~N} 17 & -0.2933 & -0.2470 & -0.2750\end{array}$

$\begin{array}{lllll}18 \mathrm{~N} 18 & 3.2938 & 0.4410 & -0.6425\end{array}$

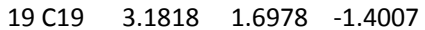

$\begin{array}{llll}20 \mathrm{C} 20 & 2.0924 & 2.5848 & -0.8210\end{array}$

$\begin{array}{lllll}21 \mathrm{C} 21 & 0.8739 & 1.8698 & -0.2606\end{array}$

$\begin{array}{lllll}22 \mathrm{C} 22 & 4.4580 & 0.1303 & 0.0421\end{array}$

$\begin{array}{llll}23 \mathrm{C} 23 & 4.5036 & -0.8332 & 1.0757\end{array}$

$\begin{array}{llll}24 \mathrm{C} 24 & 5.7346 & -1.0331 & 1.6725\end{array}$

$\begin{array}{lllll}25 \mathrm{~N} 25 & 6.8530 & -0.3700 & 1.3289\end{array}$

$\begin{array}{lllll}26 \mathrm{C} 26 & 6.6997 & 0.5371 & 0.3559\end{array}$

$\begin{array}{lllll}27 \mathrm{~N} 27 & 5.5618 & 0.8121 & -0.2988\end{array}$

$\begin{array}{lllll}28 \mathrm{C} 28 & 7.9118 & 1.3284 & -0.0573\end{array}$

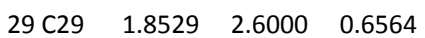

$\begin{array}{llll}30 \text { C30 } & -2.0031 & -3.4729 & -1.0312\end{array}$

$\begin{array}{llll}31 \text { C31 } & -1.8327 & -3.5436 & 0.4618\end{array}$

$\begin{array}{llll}32 \mathrm{H} 32 & -4.8733 & 3.2682 & -0.5670\end{array}$

$\begin{array}{llll}33 \mathrm{H} 33 & -7.9474 & 0.8855 & 1.2240\end{array}$

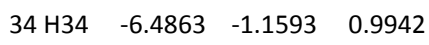

$35 \mathrm{H} 35 \quad-3.4251 \quad 1.2575 \quad-0.7972$

$\begin{array}{llll}36 \mathrm{H} 36 & -2.2914 & -0.2589 & -0.0089\end{array}$

$\begin{array}{llll}37 \mathrm{H} 37 & 0.7755 & -3.4244 & -0.6494\end{array}$

$\begin{array}{llll}38 \mathrm{H} 38 & 2.9552 & -2.2529 & -0.8293\end{array}$

$\begin{array}{llll}39 \mathrm{H} 39 & 4.1563 & 2.1828 & -1.3671\end{array}$

$40 \mathrm{H} 40 \quad 2.9493 \quad 1.4623 \quad-2.4470$

$\begin{array}{lllll}41 \mathrm{H} 41 & 1.9162 & 3.5020 & -1.3781\end{array}$

$42 \mathrm{H} 42 \quad-0.1080 \quad 2.3128 \quad-0.3907$

$\begin{array}{lllll}43 \mathrm{H} 43 & 3.6262 & -1.3711 & 1.4080\end{array}$

$44 \mathrm{H} 44 \quad 5.8357 \quad-1.7574 \quad 2.4789$

$45 \mathrm{H} 45 \quad 8.1211 \quad 1.1720 \quad-1.1204$

$\begin{array}{lllll}46 \mathrm{H} 46 & 7.7277 & 2.3991 & 0.0788\end{array}$

$\begin{array}{lllll}47 \mathrm{H} 47 & 8.7785 & 1.0295 & 0.5328\end{array}$

$\begin{array}{llll}48 \mathrm{H} 48 & 2.4940 & 1.9973 & 1.2923\end{array}$

$49 \mathrm{H} 49 \quad 1.4981 \quad 3.5182 \quad 1.1130$

$\begin{array}{llll}50 \mathrm{H} 50 & -3.0149 & -3.5784 & -1.4022\end{array}$

$\begin{array}{lllll}51 \mathrm{H} 51 & -1.2211 & -3.8476 & -1.6848\end{array}$

$\begin{array}{llll}52 \mathrm{H} 52 & -0.9244 & -3.9653 & 0.8823\end{array}$

$\begin{array}{llll}53 \mathrm{H} 53 & -2.7360 & -3.6925 & 1.0398\end{array}$

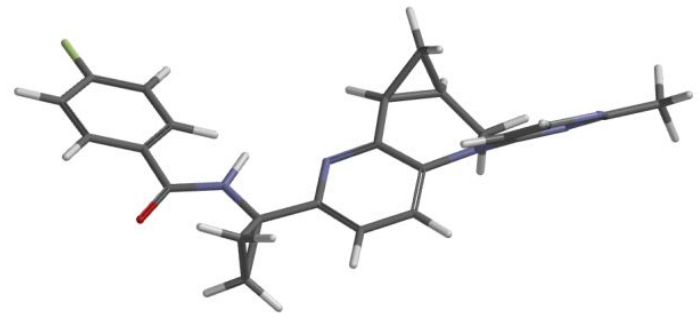

Boltzmann Population $=6.34 \%$ 


\section{Conformer \#3}

\section{Rel. Energy $=0.000 \mathrm{kcal} / \mathrm{mol}$}

$\begin{array}{llll}1 \text { C1 } & 5.8769 & -2.4732 & -0.5011\end{array}$

$\begin{array}{lllll}2 \mathrm{C} 2 & 6.7577 & -2.0210 & 0.4770\end{array}$

$\begin{array}{llll}3 \mathrm{C} 3 & 6.6091 & -0.7828 & 1.0923\end{array}$

$\begin{array}{lllll}4 \mathrm{C} 4 & 5.5321 & 0.0202 & 0.7219\end{array}$

$\begin{array}{lllll}5 \mathrm{C} 5 & 4.6177 & -0.4116 & -0.2501\end{array}$

$\begin{array}{llll}6 \text { C6 } & 4.8112 & -1.6568 & -0.8648\end{array}$

$\begin{array}{lllll}7 \text { C7 } & 3.4391 & 0.4017 & -0.7048\end{array}$

$\begin{array}{lllll}8 \text { F8 } & 7.7940 & -2.8040 & 0.8341\end{array}$

$\begin{array}{lllll}909 & 2.9116 & 0.2195 & -1.7955\end{array}$

$\begin{array}{lllll}10 & N 10 & 2.9898 & 1.3546 & 0.1821\end{array}$

$\begin{array}{llll}11 \mathrm{C} 11 & 1.8471 & 2.1798 & -0.0965\end{array}$

$\begin{array}{llll}12 \mathrm{C} 12 & 0.4978 & 1.5645 & 0.1352\end{array}$

$\begin{array}{llll}13 \mathrm{C} 13 & 0.3487 & 0.2315 & 0.5357\end{array}$

$\begin{array}{llll}14 \mathrm{C} 14 & -0.9333 & -0.2717 & 0.7277\end{array}$

$\begin{array}{llll}15 \mathrm{C} 15 & -2.0355 & 0.5475 & 0.4794\end{array}$

$\begin{array}{lllll}16 \mathrm{C} 16 & -1.7947 & 1.8830 & 0.0894\end{array}$

$\begin{array}{lllll}17 \mathrm{~N} 17 & -0.5586 & 2.3681 & -0.0629\end{array}$

$\begin{array}{llll}18 \mathrm{~N} 18 & -3.3738 & 0.1266 & 0.6800\end{array}$

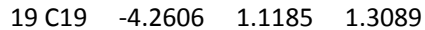

$\begin{array}{llll}20 \mathrm{C} 20 & -4.2523 & 2.4230 & 0.5291\end{array}$

$\begin{array}{llll}21 \mathrm{C} 21 & -2.9313 & 2.8135 & -0.1120\end{array}$

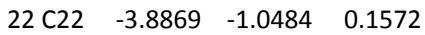

$\begin{array}{llll}23 \mathrm{C} 23 & -3.1816 & -1.8421 & -0.7773\end{array}$

$\begin{array}{llll}24 \mathrm{C} 24 & -3.8219 & -2.9855 & -1.2163\end{array}$

$\begin{array}{llll}25 \mathrm{~N} 25 & -5.0479 & -3.3642 & -0.8115\end{array}$

$\begin{array}{llll}26 \mathrm{C} 26 & -5.6399 & -2.5341 & 0.0563\end{array}$

$\begin{array}{llll}27 \mathrm{~N} 27 & -5.1179 & -1.4044 & 0.5561\end{array}$

$\begin{array}{lllll}28 \mathrm{C} 28 & -7.0242 & -2.8914 & 0.5289\end{array}$

$\begin{array}{llll}29 C 29 & -4.1279 & 2.3959 & -0.9629\end{array}$

$\begin{array}{llll}30 \text { C30 } & 2.0264 & 3.6661 & 0.1787\end{array}$

$\begin{array}{lllll}31 \text { C31 } & 1.9981 & 3.1708 & -1.2337\end{array}$

$\begin{array}{lllll}32 \mathrm{H} 32 & 6.0395 & -3.4426 & -0.9587\end{array}$

$33 \mathrm{H} 33 \quad 7.3337 \quad-0.4641 \quad 1.8331$

$\begin{array}{llll}34 \mathrm{H} 34 & 5.4329 & 1.0030 & 1.1725\end{array}$

$35 \mathrm{H} 35 \quad 4.1106 \quad-1.9629 \quad-1.6340$

$36 \mathrm{H} 36 \quad 3.2959 \quad 1.3001 \quad 1.1426$

$\begin{array}{llll}37 \mathrm{H} 37 & 1.2143 & -0.3960 & 0.7056\end{array}$

$\begin{array}{llll}38 \mathrm{H} 38 & -1.0846 & -1.2926 & 1.0632\end{array}$

$\begin{array}{llll}39 \mathrm{H} 39 & -5.2568 & 0.6806 & 1.3513\end{array}$

$\begin{array}{llll}40 \mathrm{H} 40 & -3.9188 & 1.2994 & 2.3361\end{array}$

$\begin{array}{lllll}41 \mathrm{H} 41 & -4.8407 & 3.2190 & 0.9797\end{array}$

$\begin{array}{lllll}42 \mathrm{H} 42 & -2.6425 & 3.8588 & -0.1415\end{array}$

$\begin{array}{lllll}43 \mathrm{H} 43 & -2.2062 & -1.5662 & -1.1544\end{array}$

$44 \mathrm{H} 44 \quad-3.3347 \quad-3.6357 \quad-1.9410$

$\begin{array}{llll}45 \mathrm{H} 45 & -7.0385 & -2.9897 & 1.6192\end{array}$

$\begin{array}{llll}46 \mathrm{H} 46 & -7.7286 & -2.0939 & 0.2701\end{array}$

$\begin{array}{llll}47 \mathrm{H} 47 & -7.3502 & -3.8268 & 0.0734\end{array}$

$\begin{array}{llll}48 \mathrm{H} 48 & -4.0815 & 1.4329 & -1.4622\end{array}$

$49 \mathrm{H} 49 \quad-4.6143 \quad 3.1784 \quad-1.5361$

$\begin{array}{lllll}50 \mathrm{H} 50 & 1.1514 & 4.1878 & 0.5504\end{array}$

$\begin{array}{lllll}51 \mathrm{H} 51 & 2.9799 & 3.9694 & 0.6011\end{array}$

$\begin{array}{llll}52 \mathrm{H} 52 & 2.9254 & 3.1167 & -1.7923\end{array}$

$53 \mathrm{H} 53 \quad 1.1034 \quad 3.3550 \quad-1.8173$

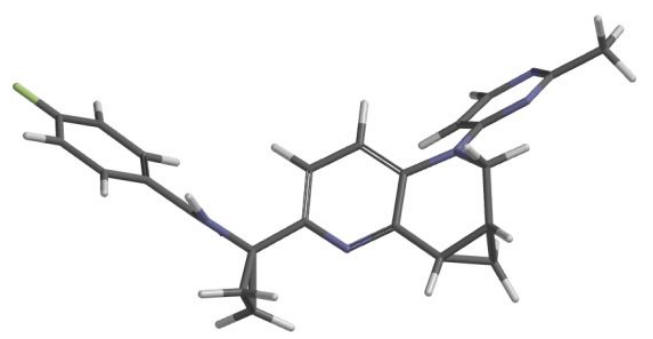

Boltzmann Population $=23.09 \%$ 


\section{Conformer \#4}

Rel. Energy $=0.104 \mathrm{kcal} / \mathrm{mol}$

$\begin{array}{llll}1 \mathrm{C} 1 & 6.1020 & 2.0566 & -1.2164\end{array}$

$\begin{array}{llll}2 \mathrm{C} 2 & 6.7726 & 2.1376 & 0.0005\end{array}$

$\begin{array}{lllll}3 \mathrm{C} 3 & 6.4563 & 1.3157 & 1.0768\end{array}$

$\begin{array}{lllll}4 \mathrm{C} 4 & 5.4230 & 0.3924 & 0.9286\end{array}$

$\begin{array}{lllll}5 \mathrm{C} 5 & 4.7174 & 0.2948 & -0.2795\end{array}$

$\begin{array}{llll}6 \text { C6 } & 5.0781 & 1.1249 & -1.3505\end{array}$

$\begin{array}{llll}7 \text { C7 } & 3.5987 & -0.6803 & -0.5147\end{array}$

$\begin{array}{llll}8 \text { F8 } & 7.7672 & 3.0355 & 0.1389\end{array}$

$\begin{array}{lllll}909 & 3.2832 & -1.0404 & -1.6424\end{array}$

$\begin{array}{llll}10 \mathrm{~N} 10 & 2.9520 & -1.1341 & 0.6132\end{array}$

$\begin{array}{llll}11 \mathrm{C} 11 & 1.8375 & -2.0382 & 0.5458\end{array}$

$\begin{array}{llll}12 \mathrm{C} 12 & 0.4970 & -1.4356 & 0.2413\end{array}$

$\begin{array}{llll}13 \mathrm{C} 13 & 0.3429 & -0.0744 & -0.0470\end{array}$

$\begin{array}{lllll}14 & \text { 14 } & -0.9290 & 0.4112 & -0.3313\end{array}$

$\begin{array}{lllll}15 \mathrm{C} 15 & -2.0204 & -0.4571 & -0.2846\end{array}$

$\begin{array}{lllll}16 \mathrm{C} 16 & -1.7744 & -1.8168 & 0.0057\end{array}$

$\begin{array}{llll}17 \mathrm{~N} 17 & -0.5453 & -2.2810 & 0.2513\end{array}$

$\begin{array}{llll}18 \mathrm{~N} 18 & -3.3435 & -0.0568 & -0.5987\end{array}$

$\begin{array}{lllll}19 & C 19 & -4.1118 & -1.0085 & -1.4180\end{array}$

$\begin{array}{llll}20 \mathrm{C} 20 & -4.1426 & -2.3808 & -0.7655\end{array}$

$\begin{array}{lllll}21 & \mathrm{C} 21 & -2.8899 & -2.7933 & -0.0113\end{array}$

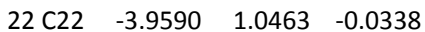

$\begin{array}{llll}23 \mathrm{C} 23 & -3.3921 & 1.7740 & 1.0389\end{array}$

$\begin{array}{llll}24 \mathrm{C} 24 & -4.1244 & 2.8492 & 1.5052\end{array}$

$\begin{array}{llll}25 \mathrm{~N} 25 & -5.3160 & 3.2224 & 1.0045\end{array}$

$\begin{array}{llll}26 \mathrm{C} 26 & -5.7757 & 2.4573 & 0.0064\end{array}$

$\begin{array}{llll}27 \mathrm{~N} 27 & -5.1553 & 1.3970 & -0.5312\end{array}$

$\begin{array}{llll}28 \mathrm{C} 28 & -7.1152 & 2.8115 & -0.5829\end{array}$

$\begin{array}{llll}29 C 29 & -4.1921 & -2.4929 & 0.7269\end{array}$

$\begin{array}{llll}30 \text { C30 } & 1.8996 & -3.2303 & 1.4913\end{array}$

$\begin{array}{llll}31 \text { C31 } & 2.1350 & -3.4307 & 0.0266\end{array}$

$\begin{array}{llll}32 \mathrm{H} 32 & 6.3909 & 2.7130 & -2.0295\end{array}$

$33 \mathrm{H} 33 \quad 7.0219 \quad 1.4002 \quad 1.9978$

$34 \mathrm{H} 34 \quad 5.1970 \quad-0.2767 \quad 1.7533$

$35 \mathrm{H} 35 \quad 4.5405 \quad 1.0170 \quad-2.2861$

$\begin{array}{llll}36 \mathrm{H} 36 & 3.0868 & -0.6329 & 1.4791\end{array}$

$\begin{array}{llll}37 \mathrm{H} 37 & 1.2004 & 0.5856 & -0.0794\end{array}$

$\begin{array}{lllll}38 \mathrm{H} 38 & -1.0796 & 1.4534 & -0.5934\end{array}$

39 H39 $-5.1128 \quad-0.5972 \quad-1.5385$

$40 \mathrm{H} 40 \quad-3.6449 \quad-1.0801 \quad-2.4085$

$\begin{array}{lllll}41 \mathrm{H} 41 & -4.6429 & -3.1464 & -1.3539\end{array}$

$\begin{array}{lllll}42 \mathrm{H} 42 & -2.5658 & -3.8281 & -0.0453\end{array}$

$\begin{array}{llll}43 \mathrm{H} 43 & -2.4501 & 1.4982 & 1.4926\end{array}$

$\begin{array}{llll}44 \mathrm{H} 44 & -3.7451 & 3.4458 & 2.3333\end{array}$

$45 \mathrm{H} 45 \quad-7.0136 \quad 3.0244 \quad-1.6521$

$\begin{array}{lllll}46 \mathrm{H} 46 & -7.8043 & 1.9658 & -0.4891\end{array}$

$\begin{array}{llll}47 \mathrm{H} 47 & -7.5340 & 3.6814 & -0.0762\end{array}$

$\begin{array}{llll}48 \mathrm{H} 48 & -4.2422 & -1.5808 & 1.3137\end{array}$

$49 \mathrm{H} 49 \quad-4.7106 \quad-3.3400 \quad 1.1641$

$\begin{array}{llll}50 \mathrm{H} 50 & 2.7525 & -3.2723 & 2.1622\end{array}$

$\begin{array}{llll}51 \mathrm{H} 51 & 0.9516 & -3.5596 & 1.9022\end{array}$

$\begin{array}{llll}52 \mathrm{H} 52 & 1.3451 & -3.8925 & -0.5546\end{array}$

$\begin{array}{llll}53 \mathrm{H} 53 & 3.1452 & -3.6012 & -0.3272\end{array}$

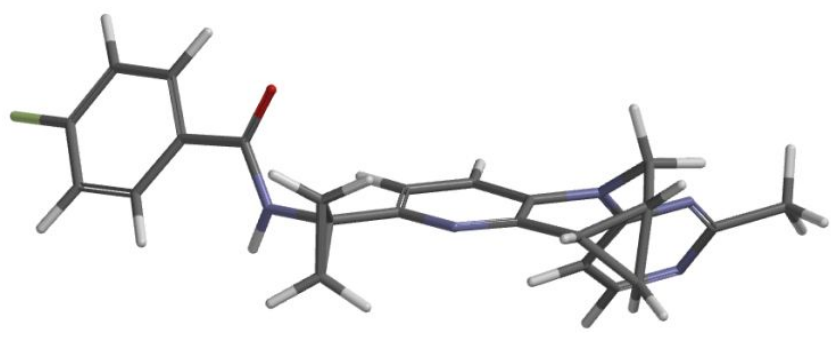

Boltzmann Population $=19.57 \%$ 


\section{Conformer \#5}

Rel. Energy $=0.140 \mathrm{kcal} / \mathrm{mol}$

$\begin{array}{llll}1 \mathrm{C} 1 & 5.9505 & -1.5246 & 1.4794\end{array}$

$\begin{array}{llll}2 \mathrm{C} 2 & 6.7869 & -2.0033 & 0.4773\end{array}$

$\begin{array}{lllll}3 \mathrm{C} 3 & 6.5747 & -1.7113 & -0.8669\end{array}$

$\begin{array}{lllll}4 \mathrm{C} 4 & 5.4922 & -0.9086 & -1.2103\end{array}$

$\begin{array}{lllll}5 & C 5 & 4.6409 & -0.3885 & -0.2250\end{array}$

$\begin{array}{llll}6 \text { C6 } & 4.8751 & -0.7145 & 1.1188\end{array}$

$\begin{array}{lllll}7 \text { C7 } & 3.4921 & 0.4618 & -0.6927\end{array}$

$\begin{array}{lllll}8 \text { F8 } & 7.8308 & -2.7831 & 0.8191\end{array}$

$\begin{array}{lllll}909 & 3.0655 & 0.3889 & -1.8394\end{array}$

$\begin{array}{llll}10 \mathrm{~N} 10 & 2.9631 & 1.3242 & 0.2373\end{array}$

$\begin{array}{llll}11 \mathrm{C} 11 & 1.8308 & 2.1665 & -0.0317\end{array}$

$\begin{array}{llll}12 \mathrm{C} 12 & 0.4806 & 1.5465 & 0.1810\end{array}$

$\begin{array}{llll}13 \mathrm{C} 13 & 0.3310 & 0.2008 & 0.5359\end{array}$

$\begin{array}{llll}14 \mathrm{C} 14 & -0.9518 & -0.3088 & 0.7059\end{array}$

$\begin{array}{llll}15 \mathrm{C} 15 & -2.0533 & 0.5183 & 0.4818\end{array}$

$\begin{array}{lllll}16 \mathrm{C} 16 & -1.8115 & 1.8663 & 0.1378\end{array}$

$\begin{array}{llll}17 \mathrm{~N} 17 & -0.5750 & 2.3564 & 0.0055\end{array}$

$\begin{array}{lllll}18 \mathrm{~N} 18 & -3.3923 & 0.0911 & 0.6640\end{array}$

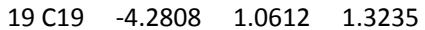

$\begin{array}{llll}20 \mathrm{C} 20 & -4.2705 & 2.3913 & 0.5882\end{array}$

$\begin{array}{lllll}21 \mathrm{C} 21 & -2.9476 & 2.8031 & -0.0354\end{array}$

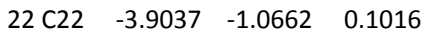

$\begin{array}{llll}23 \mathrm{C} 23 & -3.1956 & -1.8295 & -0.8559\end{array}$

$\begin{array}{llll}24 \mathrm{C} 24 & -3.8347 & -2.9579 & -1.3338\end{array}$

$\begin{array}{llll}25 \mathrm{~N} 25 & -5.0622 & -3.3490 & -0.9455\end{array}$

$\begin{array}{lllll}26 \mathrm{C} 26 & -5.6568 & -2.5474 & -0.0532\end{array}$

$\begin{array}{llll}27 \mathrm{~N} 27 & -5.1361 & -1.4347 & 0.4847\end{array}$

$\begin{array}{lllll}28 \mathrm{C} 28 & -7.0427 & -2.9192 & 0.4029\end{array}$

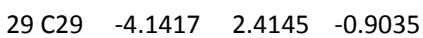

$\begin{array}{llll}30 \text { C30 } & 1.9817 & 3.1879 & -1.1448\end{array}$

$\begin{array}{lllll}31 \text { C31 } & 2.0108 & 3.6449 & 0.2800\end{array}$

$\begin{array}{llll}32 \mathrm{H} 32 & 6.1425 & -1.7966 & 2.5111\end{array}$

$33 \mathrm{H} 33 \quad 7.2490 \quad-2.1154 \quad-1.6137$

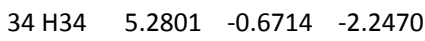

$\begin{array}{llll}35 \mathrm{H} 35 & 4.2014 & -0.3703 & 1.8981\end{array}$

$\begin{array}{llll}36 \mathrm{H} 36 & 3.4118 & 1.4161 & 1.1355\end{array}$

$\begin{array}{llll}37 \mathrm{H} 37 & 1.1983 & -0.4286 & 0.6897\end{array}$

$\begin{array}{llll}38 \mathrm{H} 38 & -1.1041 & -1.3404 & 1.0064\end{array}$

$\begin{array}{llll}39 \mathrm{H} 39 & -5.2772 & 0.6222 & 1.3483\end{array}$

$\begin{array}{llll}40 \mathrm{H} 40 & -3.9419 & 1.2073 & 2.3572\end{array}$

$\begin{array}{llll}41 \mathrm{H} 41 & -4.8602 & 3.1717 & 1.0637\end{array}$

$\begin{array}{lllll}42 \mathrm{H} 42 & -2.6588 & 3.8488 & -0.0287\end{array}$

$\begin{array}{llll}43 \mathrm{H} 43 & -2.2188 & -1.5422 & -1.2204\end{array}$

$44 \mathrm{H} 44 \quad-3.3451 \quad-3.5845 \quad-2.0773$

$\begin{array}{llll}45 \mathrm{H} 45 & -7.0610 & -3.0523 & 1.4894\end{array}$

$\begin{array}{llll}46 \mathrm{H} 46 & -7.7462 & -2.1139 & 0.1670\end{array}$

$\begin{array}{llll}47 \mathrm{H} 47 & -7.3671 & -3.8397 & -0.0833\end{array}$

$\begin{array}{lllll}48 \mathrm{H} 48 & -4.0937 & 1.4688 & -1.4346\end{array}$

$49 \mathrm{H} 49 \quad-4.6265 \quad 3.2158 \quad-1.4515$

$\begin{array}{lllll}50 \mathrm{H} 50 & 2.9073 & 3.1434 & -1.7063\end{array}$

$\begin{array}{lllll}51 \mathrm{H} 51 & 1.0864 & 3.3881 & -1.7225\end{array}$

$\begin{array}{llll}52 \mathrm{H} 52 & 1.1363 & 4.1560 & 0.6673\end{array}$

$\begin{array}{llll}53 \mathrm{H} 53 & 2.9640 & 3.9406 & 0.7092\end{array}$

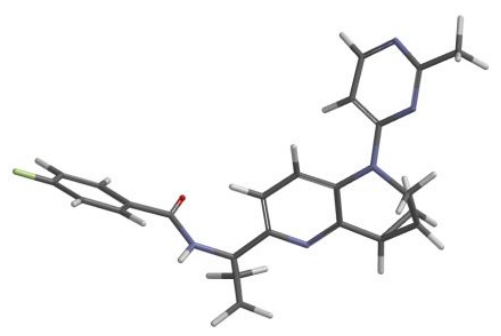

Boltzmann Population $=18.42 \%$ 


\section{Conformer \#6}

Rel. Energy $=0.246 \mathrm{kcal} / \mathrm{mol}$

$\begin{array}{llll}1 \mathrm{C} 1 & -5.7599 & -2.1741 & 0.9000\end{array}$

$\begin{array}{llll}2 \mathrm{C} 2 & -6.7854 & -2.1551 & -0.0386\end{array}$

$\begin{array}{lllll}3 \mathrm{C} 3 & -6.8095 & -1.2446 & -1.0911\end{array}$

$\begin{array}{lllll}4 \mathrm{C} 4 & -5.7738 & -0.3225 & -1.1967\end{array}$

$\begin{array}{lllll}5 & C 5 & -4.7350 & -0.2963 & -0.2552\end{array}$

$\begin{array}{llll}6 \mathrm{C} 6 & -4.7339 & -1.2376 & 0.7845\end{array}$

$\begin{array}{llll}7 \mathrm{C7} & -3.6547 & 0.7303 & -0.4566\end{array}$

$\begin{array}{lllll}8 \text { F8 } & -7.7825 & -3.0544 & 0.0696\end{array}$

$\begin{array}{lllll}909 & -3.4467 & 1.2353 & -1.5537\end{array}$

$\begin{array}{llll}10 \mathrm{~N} 10 & -2.9302 & 1.0688 & 0.6613\end{array}$

$\begin{array}{llll}11 \mathrm{C} 11 & -1.8304 & 1.9925 & 0.6332\end{array}$

$\begin{array}{llll}12 \mathrm{C} 12 & -0.4871 & 1.4107 & 0.3018\end{array}$

$\begin{array}{llll}13 \mathrm{C} 13 & -0.3295 & 0.0662 & -0.0545\end{array}$

$\begin{array}{llll}14 \mathrm{C} 14 & 0.9432 & -0.3993 & -0.3678\end{array}$

$\begin{array}{llll}15 \mathrm{C} 15 & 2.0314 & 0.4701 & -0.2812\end{array}$

$\begin{array}{llll}16 \mathrm{C} 16 & 1.7815 & 1.8125 & 0.0780\end{array}$

$\begin{array}{llll}17 \mathrm{~N} 17 & 0.5515 & 2.2592 & 0.3501\end{array}$

$\begin{array}{lllll}18 \mathrm{~N} 18 & 3.3549 & 0.0912 & -0.6196\end{array}$

19 C19 $4.1165 \quad 1.0856-1.3929$

$\begin{array}{llll}20 \mathrm{C} 20 & 4.1449 & 2.4235 & -0.6724\end{array}$

$\begin{array}{llll}21 \mathrm{C} 21 & 2.8936 & 2.7927 & 0.1064\end{array}$

$\begin{array}{lllll}22 & \mathrm{C} 22 & 3.9773 & -1.0348 & -0.1103\end{array}$

$\begin{array}{llll}23 \mathrm{C} 23 & 3.4169 & -1.8165 & 0.9273\end{array}$

$\begin{array}{llll}24 \mathrm{C} 24 & 4.1559 & -2.9091 & 1.3394\end{array}$

$\begin{array}{llll}25 \mathrm{~N} 25 & 5.3480 & -3.2515 & 0.8186\end{array}$

$\begin{array}{lllll}26 \mathrm{C} 26 & 5.8012 & -2.4368 & -0.1428\end{array}$

$\begin{array}{llll}27 \mathrm{~N} 27 & 5.1741 & -1.3550 & -0.6269\end{array}$

$\begin{array}{llll}28 \mathrm{C} 28 & 7.1406 & -2.7556 & -0.7521\end{array}$

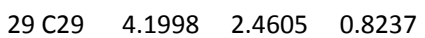

$\begin{array}{llll}30 \text { C30 } & -1.8984 & 3.1409 & 1.6301\end{array}$

$\begin{array}{llll}31 \text { C31 } & -2.1315 & 3.4084 & 0.1764\end{array}$

$\begin{array}{llll}32 \mathrm{H} 32 & -5.7720 & -2.9164 & 1.6899\end{array}$

$33 \mathrm{H} 33 \quad-7.6258 \quad-1.2746 \quad-1.8041$

$\begin{array}{lllll}34 & \text { H34 } & -5.7442 & 0.3925 & -2.0114\end{array}$

$\begin{array}{llll}35 \mathrm{H} 35 & -3.9147 & -1.2755 & 1.4965\end{array}$

$\begin{array}{llll}36 \mathrm{H} 36 & -3.2075 & 0.6994 & 1.5575\end{array}$

37 H37 $\quad-1.1864 \quad-0.5929 \quad-0.1128$

$\begin{array}{llll}38 \mathrm{H} 38 & 1.0970 & -1.4264 & -0.6823\end{array}$

$\begin{array}{llll}39 \mathrm{H} 39 & 5.1185 & 0.6847 & -1.5376\end{array}$

$\begin{array}{lllll}40 \mathrm{H} 40 & 3.6453 & 1.2050 & -2.3767\end{array}$

$41 \mathrm{H} 41 \quad 4.6401 \quad 3.2197 \quad-1.2232$

$\begin{array}{lllll}42 \mathrm{H} 42 & 2.5657 & 3.8266 & 0.1258\end{array}$

$\begin{array}{lllll}43 \mathrm{H} 43 & 2.4746 & -1.5679 & 1.3960\end{array}$

$44 \mathrm{H} 44 \quad 3.7818 \quad-3.5468 \quad 2.1387$

$45 \mathrm{H} 45 \quad 7.0360 \quad-2.9209 \quad-1.8293$

$46 \mathrm{H} 46 \quad 7.8249 \quad-1.9107 \quad-0.6228$

$\begin{array}{llll}47 \mathrm{H} 47 & 7.5665 & -3.6449 & -0.2868\end{array}$

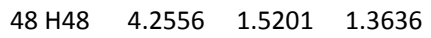

$\begin{array}{lllll}49 \mathrm{H} 49 & 4.7169 & 3.2865 & 1.3011\end{array}$

$\begin{array}{llll}50 \mathrm{H} 50 & -2.7522 & 3.1532 & 2.3019\end{array}$

$\begin{array}{llll}51 \mathrm{H} 51 & -0.9521 & 3.4520 & 2.0587\end{array}$

$\begin{array}{llll}52 \mathrm{H} 52 & -1.3415 & 3.8987 & -0.3809\end{array}$

$\begin{array}{llll}53 \mathrm{H} 53 & -3.1405 & 3.5883 & -0.1749\end{array}$

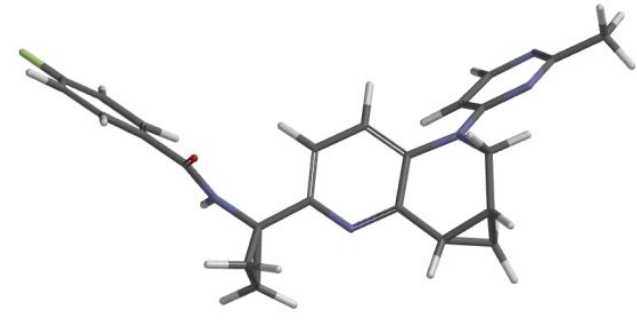

Boltzmann Population $=15.40 \%$ 


\section{Determination of Absolution Stereoconfiguration of compound $\mathbf{6}$}

The Experimental versus Calculated IR and VCD spectra are shown below. Calculations are from the Boltzmann-weighted average spectra.

$-\operatorname{Exp}$

- Calc 21S, 20R

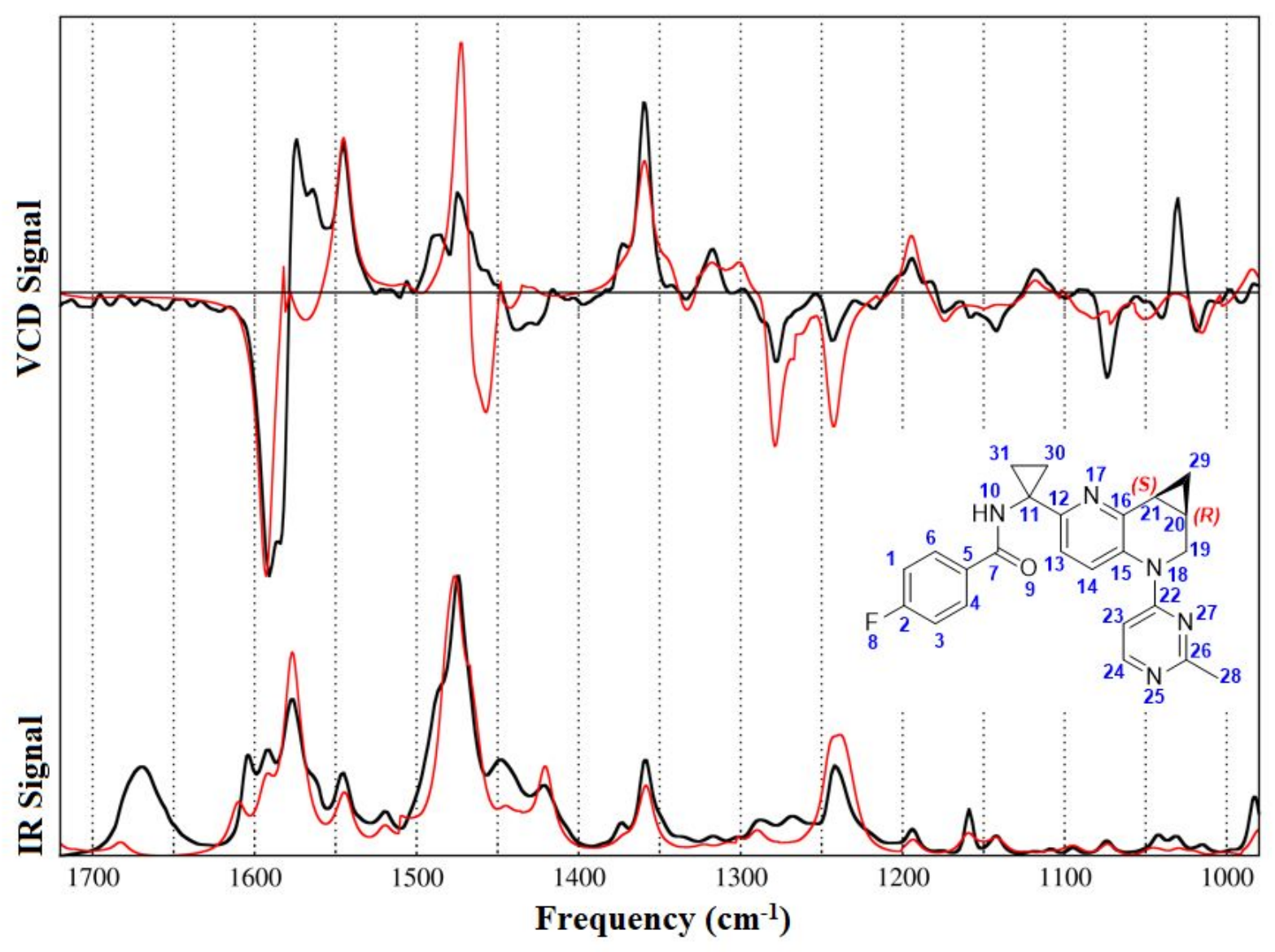

Integrated Comparison Results

Maximum shift of IR \& VCD spectral bands $=25 \mathrm{~cm}^{-1}$

Unshifted IR $=0.703$

Final Shifted IR $=0.864$

Unshifted VCD for $(21 S, 20 R)=0.172$

Final Shifted VCD for $(21 S, 20 R)=0.649$

Unshifted VCD for enantiomer $(21 R, 20 S)=-0.172$

Final Shifted VCD for enantiomer $(21 R, 20 S)=-0.089$

\section{Conclusions}

VCD calculations exhibit a high quality match for the $(21 S, 20 R)$ configuration. 


\section{$\underline{\text { Relative Stereochemistry Determination of compound } \mathbf{5}}$}

The relative stereochemistry was determined by the following set of NOEs from the NOESY NMR spectrum.<smiles></smiles>

key NOEs

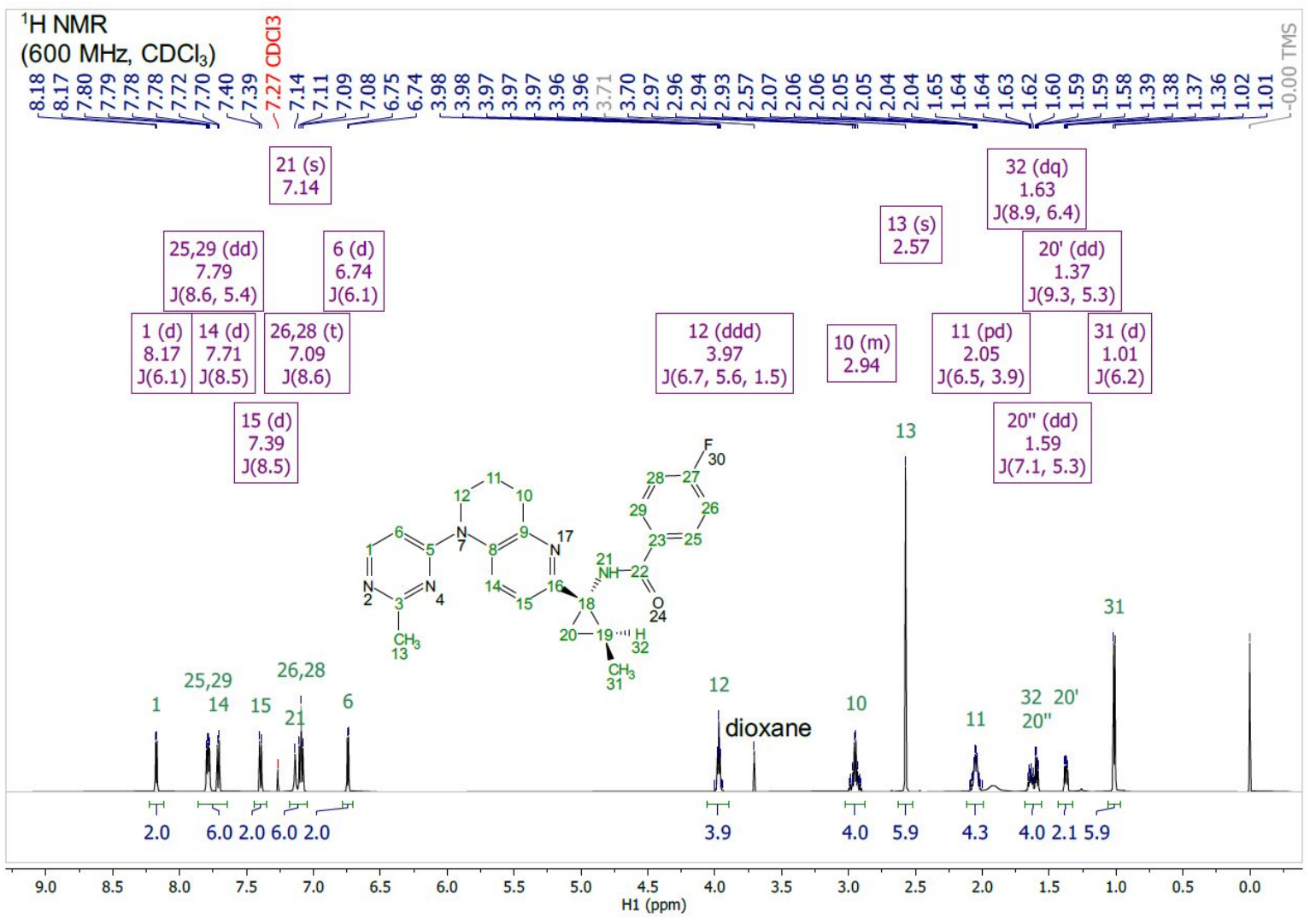




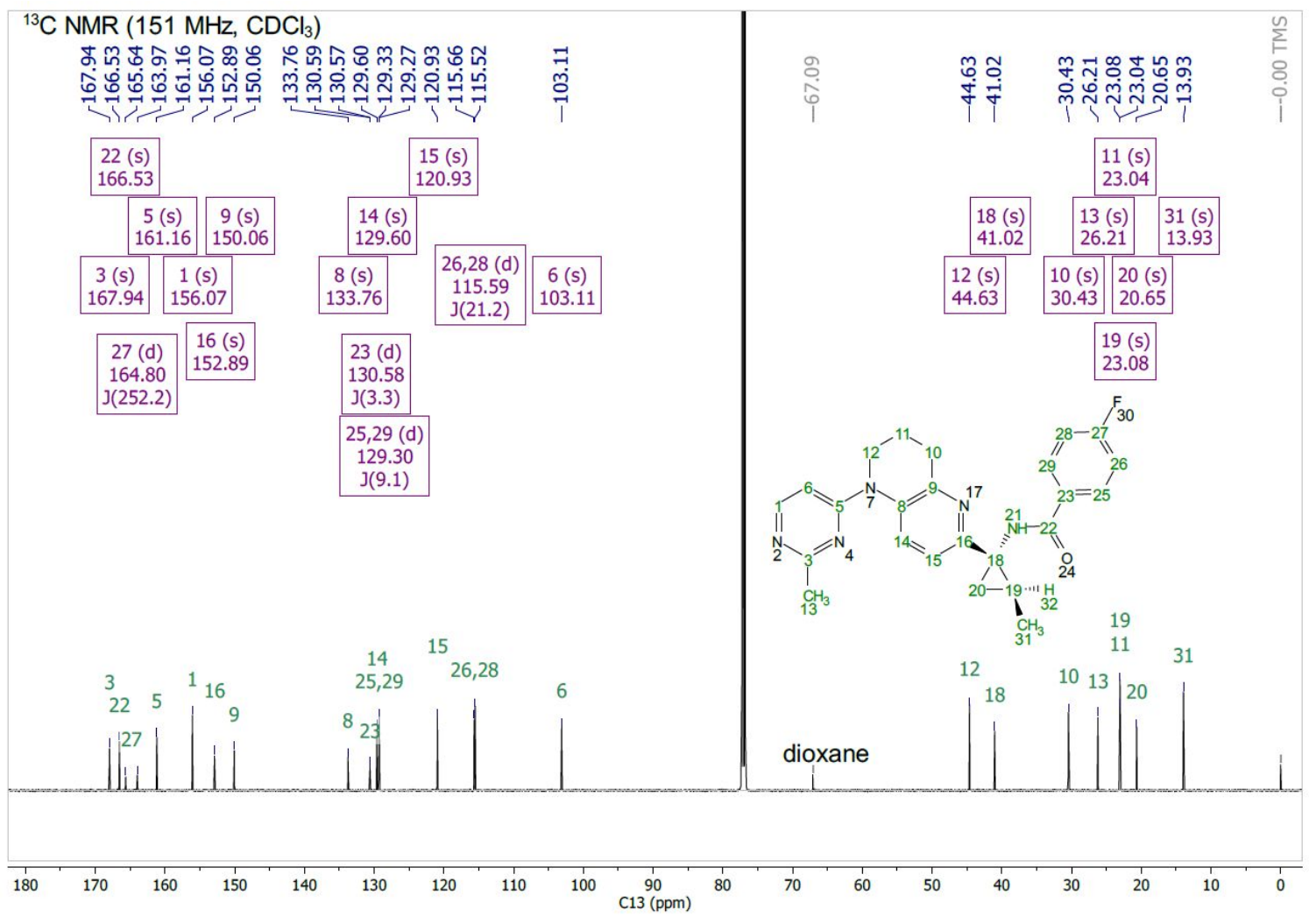

${ }^{1} \mathrm{H} /{ }^{1} \mathrm{H}$ COSY NMR $\left(600 / 600 \mathrm{MHz}, \mathrm{CDCl}_{3}\right)$

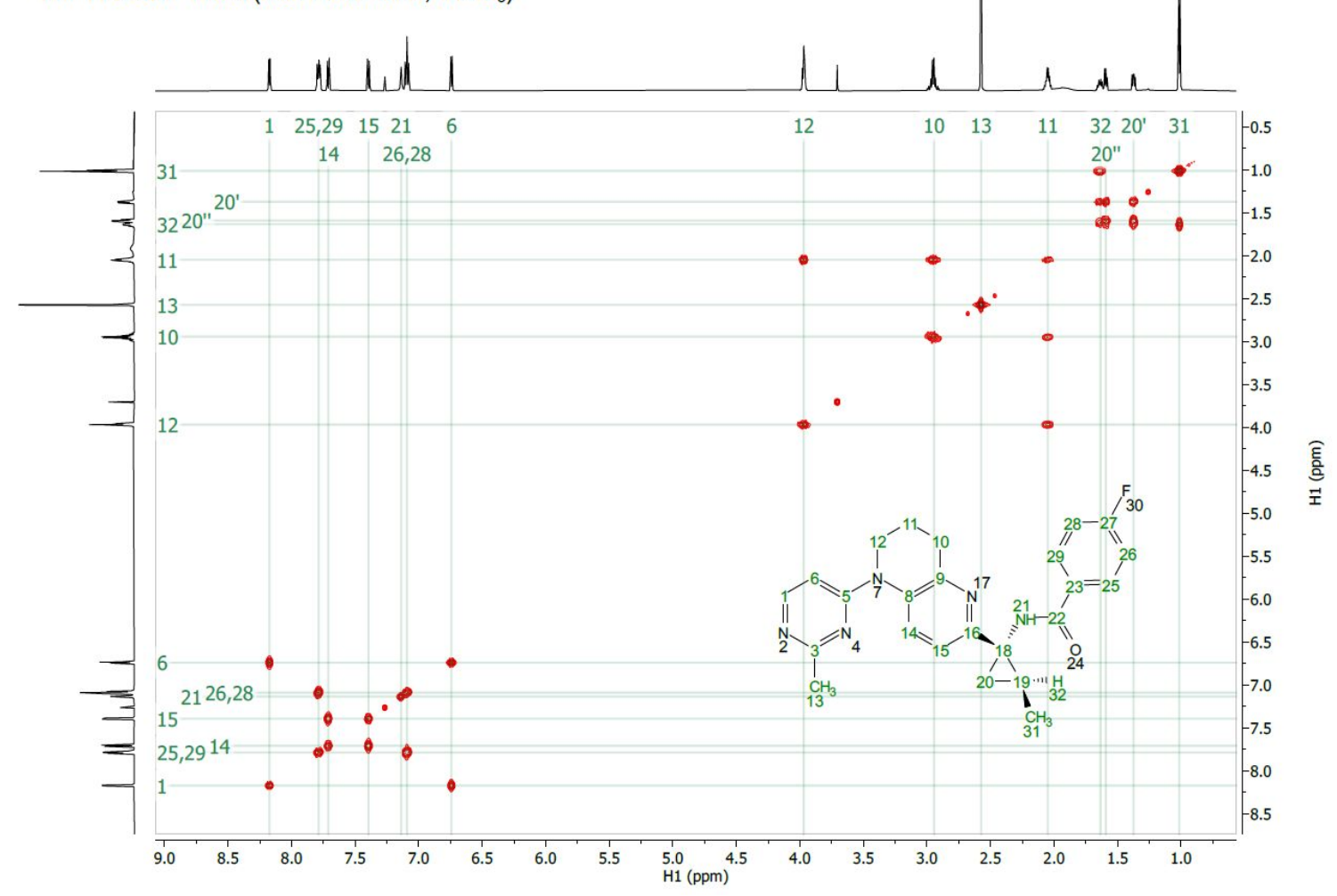


${ }^{1} \mathrm{H} /{ }^{13} \mathrm{C}$ HSQC NMR $\left(600 / 151 \mathrm{MHz}, \mathrm{CDCl}_{3}\right)$

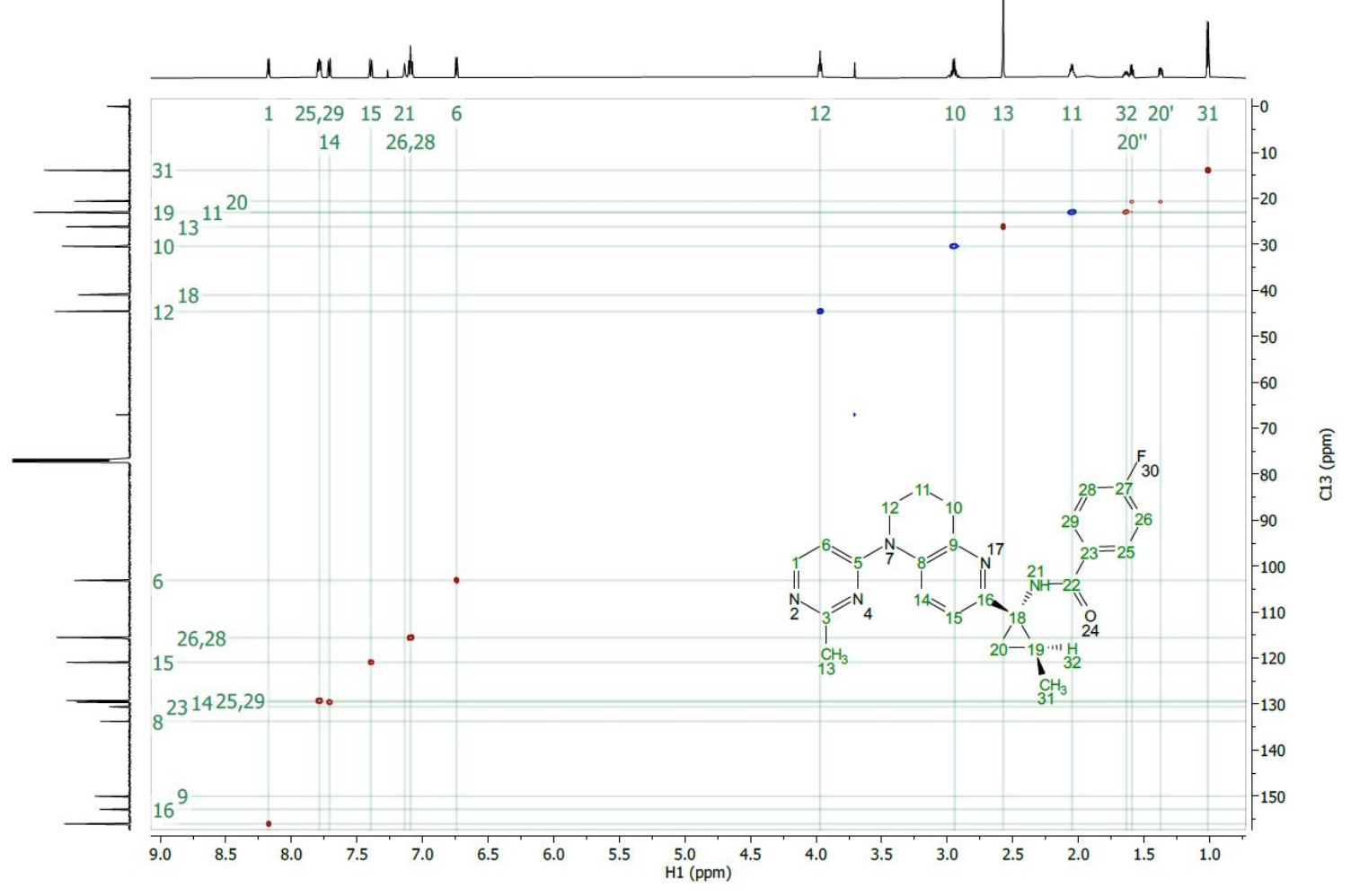

${ }^{1} \mathrm{H} /{ }^{13} \mathrm{C} \mathrm{HMBC}$ NMR $\left(600 / 151 \mathrm{MHz}, \mathrm{CDCl}_{3}\right)$

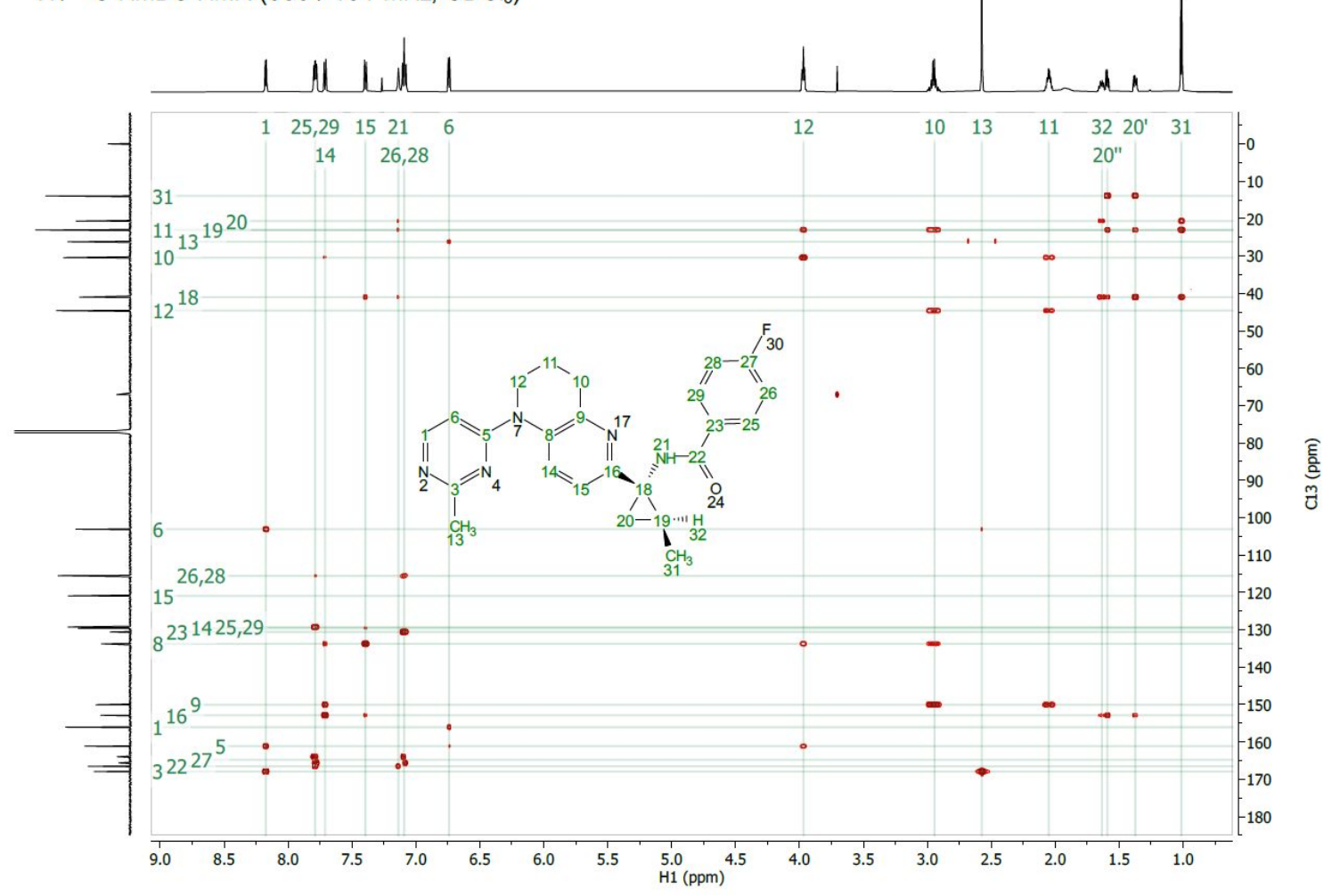


${ }^{1} \mathrm{H} /{ }^{15} \mathrm{~N} \mathrm{HMBC}$ NMR $\left(600 / 61 \mathrm{MHz}, \mathrm{CDCl}_{3}\right)$

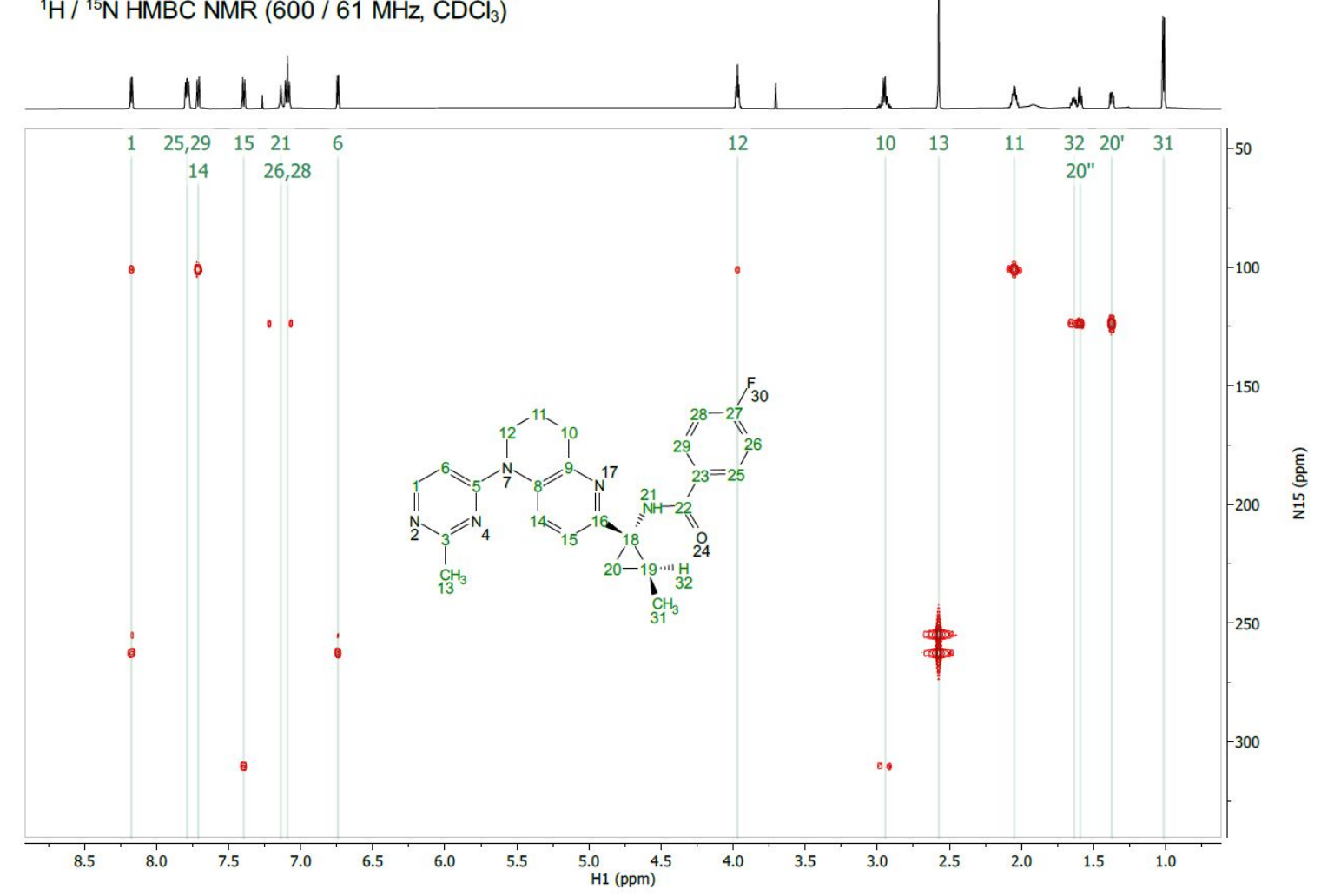

${ }^{1} \mathrm{H} /{ }^{1} \mathrm{H}$ NOESY NMR $\left(600 / 600 \mathrm{MHz}, \mathrm{CDCl}_{3}\right)$

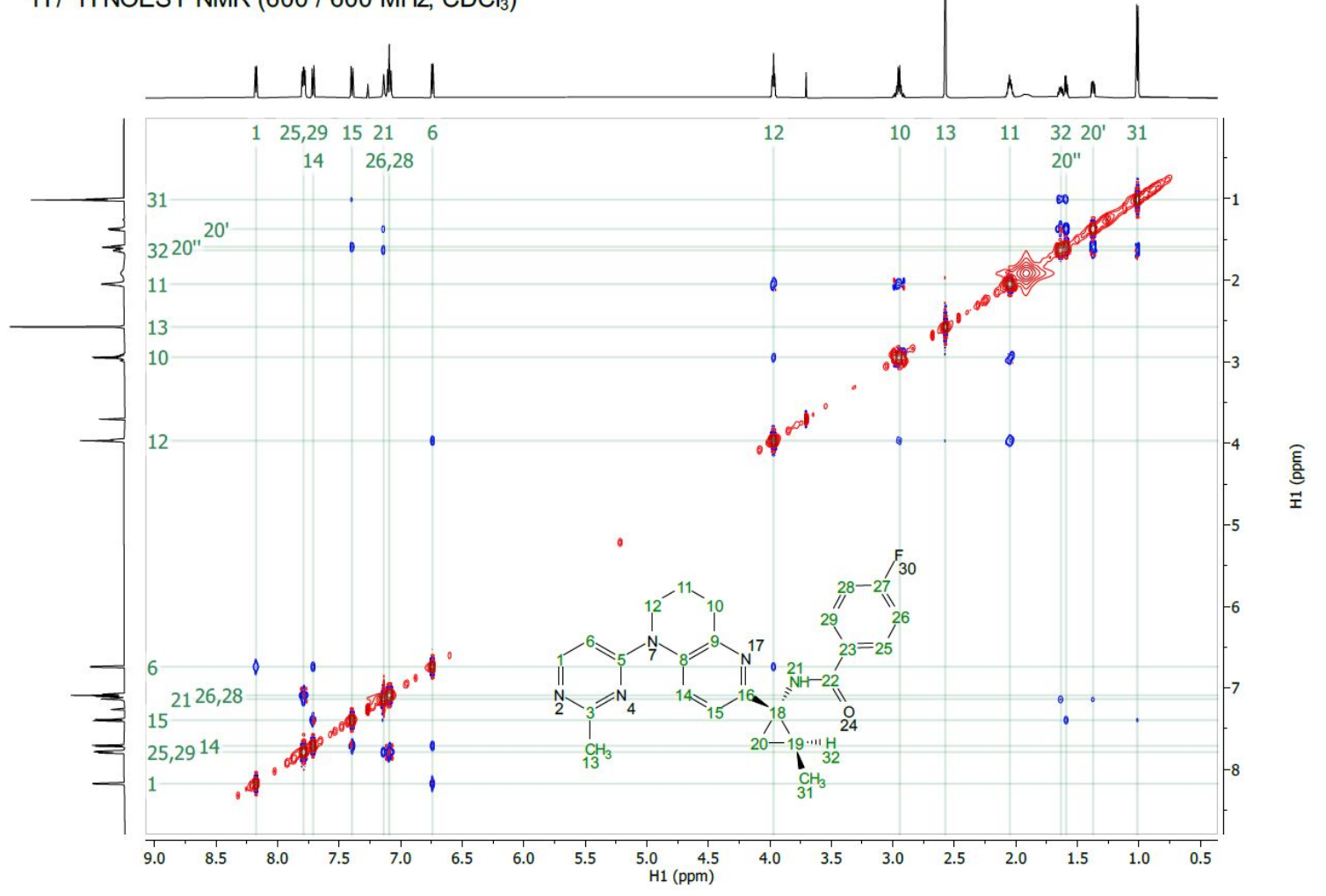




\section{DFT Calculation Results for compound 5}

The following is the calculated Boltzmann distribution at the B3LYP-D3/6-31G(d,p) level of theory showing the 20 lowest energy conformers. The cartesian coordinates for the energy minimized structures of the lowest 6 energy conformers are provided.

\begin{tabular}{|c|c|c|}
\hline Conformer & $\begin{array}{c}\text { Relative Energy } \\
(\mathrm{kcal} / \mathrm{mol})\end{array}$ & $\begin{array}{c}\text { Boltzmann } \\
\text { Population }\end{array}$ \\
\hline 1 & 0.000 & 17.81 \\
\hline 2 & 0.014 & 17.40 \\
\hline 3 & 0.748 & 5.04 \\
\hline 4 & 0.298 & 10.77 \\
\hline 5 & 0.744 & 5.07 \\
\hline 6 & 0.252 & 11.64 \\
\hline 7 & 1.036 & 3.10 \\
\hline 8 & 0.980 & 3.41 \\
\hline 9 & 1.202 & 2.34 \\
\hline 10 & 1.328 & 1.89 \\
\hline 11 & 1.724 & 0.97 \\
\hline 12 & 1.112 & 2.73 \\
\hline 13 & 1.144 & 2.58 \\
\hline 14 & 1.200 & 2.35 \\
\hline 15 & 1.938 & 0.68 \\
\hline 16 & 1.736 & 0.95 \\
\hline 17 & 1.402 & 1.67 \\
\hline 18 & 2.040 & 0.57 \\
\hline 19 & 1.764 & 0.91 \\
\hline 20 & 2.432 & 0.29 \\
\hline & & 92.2 \\
\hline
\end{tabular}




\section{Conformer \#1}

Rel. Energy $=0.000 \mathrm{kcal} / \mathrm{mol}$

$\begin{array}{llll}1 \mathrm{C} 1 & -3.8424 & -3.3127 & 0.5177\end{array}$

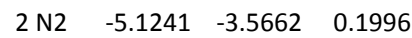

$\begin{array}{lllll}3 \mathrm{C} 3 & -5.8267 & -2.5021 & -0.2104\end{array}$

$\begin{array}{lllll}4 \mathrm{~N} 4 & -5.3637 & -1.2518 & -0.3488\end{array}$

$\begin{array}{lllll}5 \mathrm{C} 5 & -4.0754 & -1.0164 & -0.0516\end{array}$

$\begin{array}{llll}6 \mathrm{C} 6 & -3.2533 & -2.0658 & 0.4203\end{array}$

$\begin{array}{lllll}7 \text { N7 } & -3.6325 & 0.2892 & -0.2047\end{array}$

$\begin{array}{lllll}8 \mathrm{C} 8 & -2.2732 & 0.6700 & -0.1100\end{array}$

$\begin{array}{llll}9 \text { C9 } & -1.9180 & 1.8636 & 0.5482\end{array}$

$\begin{array}{llll}10 \mathrm{C} 10 & -2.9591 & 2.7951 & 1.1338\end{array}$

$\begin{array}{llll}11 \text { C11 } & -4.3747 & 2.2033 & 1.1198\end{array}$

$\begin{array}{lllll}12 \mathrm{C} 12 & -4.5973 & 1.3996 & -0.1643\end{array}$

$\begin{array}{lllll}13 \mathrm{C} 13 & -7.2759 & -2.7162 & -0.5582\end{array}$

$\begin{array}{llll}14 \mathrm{C} 14 & -1.2498 & -0.0501 & -0.7459\end{array}$

$\begin{array}{llll}15 \mathrm{C} 15 & 0.0630 & 0.3799 & -0.6411\end{array}$

$\begin{array}{llll}16 \mathrm{C} 16 & 0.3353 & 1.5459 & 0.0924\end{array}$

$\begin{array}{llll}17 \mathrm{~N} 17 & -0.6447 & 2.2700 & 0.6435\end{array}$

$\begin{array}{llll}18 \mathrm{C} 18 & 1.7463 & 2.0484 & 0.2362\end{array}$

$\begin{array}{llll}19 \mathrm{C} 19 & 2.1971 & 3.2748 & -0.5496\end{array}$

$\begin{array}{llll}20 \mathrm{C} 20 & 2.0046 & 3.3672 & 0.9383\end{array}$

$\begin{array}{llll}21 \mathrm{~N} 21 & 2.7512 & 1.0317 & 0.4305\end{array}$

$\begin{array}{lllll}22 & \mathrm{C} 22 & 3.3926 & 0.3883 & -0.5964\end{array}$

$\begin{array}{lllll}23 \mathrm{C} 23 & 4.4541 & -0.5960 & -0.1955\end{array}$

$\begin{array}{lllll}24 & 024 & 3.1177 & 0.5896 & -1.7776\end{array}$

$\begin{array}{llll}25 \mathrm{C} 25 & 5.1385 & -0.5451 & 1.0276\end{array}$

$\begin{array}{llll}26 \mathrm{C} 26 & 6.1214 & -1.4845 & 1.3329\end{array}$

$\begin{array}{llll}27 \mathrm{C} 27 & 6.4099 & -2.4725 & 0.3979\end{array}$

$\begin{array}{lllll}28 C 28 & 5.7604 & -2.5424 & -0.8312\end{array}$

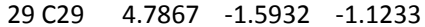

$\begin{array}{llll}30 \text { F30 } & 7.3559 & -3.3863 & 0.6885\end{array}$

$\begin{array}{llll}31 \text { C31 } & 1.2659 & 3.9590 & -1.5230\end{array}$

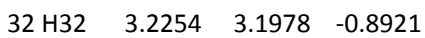

$\begin{array}{llll}33 \mathrm{H} 33 & -3.2627 & -4.1594 & 0.8816\end{array}$

$\begin{array}{llll}34 \mathrm{H} 34 & -2.2268 & -1.9096 & 0.7218\end{array}$

$\begin{array}{llll}35 \mathrm{H} 35 & -2.6519 & 3.0803 & 2.1452\end{array}$

$\begin{array}{llll}36 \mathrm{H} 36 & -2.9345 & 3.7197 & 0.5415\end{array}$

$\begin{array}{llll}37 \mathrm{H} 37 & -4.5191 & 1.5305 & 1.9732\end{array}$

$\begin{array}{llll}38 \mathrm{H} 38 & -5.1231 & 2.9984 & 1.2039\end{array}$

$39 \mathrm{H} 39 \quad-4.4425 \quad 2.0311 \quad-1.0481$

$\begin{array}{lllll}40 \mathrm{H} 40 & -5.5961 & 0.9724 & -0.2197\end{array}$

$\begin{array}{lllll}41 \mathrm{H} 41 & -7.5527 & -3.7593 & -0.4031\end{array}$

$\begin{array}{llll}42 \mathrm{H} 42 & -7.9116 & -2.0726 & 0.0586\end{array}$

$43 \mathrm{H} 43 \quad-7.4588 \quad-2.4408 \quad-1.6020$

$\begin{array}{llll}44 \mathrm{H} 44 & -1.4953 & -0.9282 & -1.3335\end{array}$

$\begin{array}{lllll}45 \mathrm{H} 45 & 0.8607 & -0.1396 & -1.1572\end{array}$

$\begin{array}{llll}46 \mathrm{H} 46 & 1.1250 & 3.8804 & 1.3110\end{array}$

$\begin{array}{llll}47 \mathrm{H} 47 & 2.8848 & 3.4176 & 1.5722\end{array}$

$\begin{array}{lllll}48 \mathrm{H} 48 & 2.8557 & 0.6683 & 1.3666\end{array}$

$\begin{array}{llll}49 \mathrm{H} 49 & 4.9359 & 0.2501 & 1.7386\end{array}$

$\begin{array}{llll}50 \mathrm{H} 50 & 6.6697 & -1.4572 & 2.2678\end{array}$

$\begin{array}{llll}51 \mathrm{H} 51 & 6.0264 & -3.3261 & -1.5315\end{array}$

$52 \mathrm{H} 52 \quad 4.2681 \quad-1.6011 \quad-2.0756$

$\begin{array}{lllll}53 \mathrm{H} 53 & 1.6120 & 4.9773 & -1.7293\end{array}$

$54 \mathrm{H} 54 \quad 0.2494 \quad 4.0217 \quad-1.1265$

$\begin{array}{llll}55 \mathrm{H} 55 & 1.2349 & 3.4081 & -2.4685\end{array}$

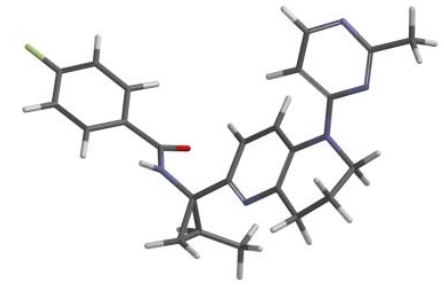

Boltzmann Population $=17.81 \%$ 


\section{Conformer \#2}

Rel. Energy $=0.014 \mathrm{kcal} / \mathrm{mol}$

1 C1 $\quad-4.5736 \quad-2.2969-1.8076$

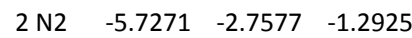

$\begin{array}{llll}3 \mathrm{C} 3 & -6.0696 & -2.2311 & -0.1096\end{array}$

$\begin{array}{llll}4 \mathrm{~N} 4 & -5.3651 & -1.3318 & 0.5916\end{array}$

$\begin{array}{lllll}5 \text { C5 } & -4.2024 & -0.8986 & 0.0782\end{array}$

$\begin{array}{llll}6 \mathrm{C} 6 & -3.7640 & -1.3671 & -1.1815\end{array}$

$\begin{array}{lllll}7 \text { N7 } & -3.5018 & 0.0332 & 0.8319\end{array}$

$\begin{array}{lllll}8 \mathrm{C} 8 & -2.1832 & 0.4483 & 0.5313\end{array}$

$\begin{array}{llll}9 \text { C9 } & -1.8257 & 1.8054 & 0.6513\end{array}$

$\begin{array}{llll}10 \mathrm{C} 10 & -2.8133 & 2.8558 & 1.1164\end{array}$

$\begin{array}{llll}11 \mathrm{C} 11 & -4.2452 & 2.3212 & 1.2534\end{array}$

$\begin{array}{llll}12 \mathrm{C} 12 & -4.2224 & 0.8870 & 1.7894\end{array}$

$\begin{array}{llll}13 \mathrm{C} 13 & -7.3657 & -2.6869 & 0.5067\end{array}$

$\begin{array}{llll}14 C 14 & -1.1699 & -0.4629 & 0.1950\end{array}$

$\begin{array}{llll}15 \mathrm{C} 15 & 0.1109 & -0.0035 & -0.0656\end{array}$

$\begin{array}{llll}16 \mathrm{C} 16 & 0.3751 & 1.3700 & 0.0549\end{array}$

$\begin{array}{llll}17 \mathrm{~N} 17 & -0.5781 & 2.2352 & 0.4190\end{array}$

$\begin{array}{llll}18 \mathrm{C} 18 & 1.7413 & 1.9205 & -0.2510\end{array}$

19 C19 $1.9562 \quad 2.7539-1.5102$

$\begin{array}{lllll}20 \mathrm{C} 20 & 1.9846 & 3.4146 & -0.1606\end{array}$

$\begin{array}{llll}21 \mathrm{~N} 21 & 2.8515 & 1.0840 & 0.1334\end{array}$

$\begin{array}{lllll}22 & \mathrm{C} 22 & 3.3801 & 0.1063 & -0.6701\end{array}$

$\begin{array}{lllll}23 \mathrm{C} 23 & 4.5778 & -0.6178 & -0.1245\end{array}$

$\begin{array}{lllll}24 & 024 & 2.9049 & -0.1754 & -1.7680\end{array}$

$\begin{array}{lllll}25 \mathrm{C} 25 & 5.4382 & -0.0773 & 0.8421\end{array}$

$\begin{array}{lllll}26 \mathrm{C} 26 & 6.5397 & -0.7990 & 1.2979\end{array}$

$\begin{array}{llll}27 \mathrm{C} 27 & 6.7677 & -2.0662 & 0.7725\end{array}$

$\begin{array}{lllll}28 C 28 & 5.9423 & -2.6257 & -0.1985\end{array}$

$\begin{array}{lllll}29 & \mathrm{C} 29 & 4.8511 & -1.8896 & -0.6477\end{array}$

$\begin{array}{llll}30 \text { F30 } & 7.8283 & -2.7708 & 1.2120\end{array}$

$\begin{array}{lllll}31 \text { C31 } & 0.8327 & 2.9827 & -2.4944\end{array}$

$32 \mathrm{H} 32 \quad 2.9237 \quad 2.5728 \quad-1.9706$

$33 \mathrm{H} 33 \quad-4.2934 \quad-2.6901 \quad-2.7834$

$\begin{array}{llll}34 \mathrm{H} 34 & -2.8639 & -1.0027 & -1.6571\end{array}$

$\begin{array}{lllll}35 \mathrm{H} 35 & -2.4577 & 3.2270 & 2.0868\end{array}$

$\begin{array}{llll}36 \mathrm{H} 36 & -2.7669 & 3.7116 & 0.4348\end{array}$

$\begin{array}{llll}37 \mathrm{H} 37 & -4.8330 & 2.9653 & 1.9161\end{array}$

$\begin{array}{lllll}38 \mathrm{H} 38 & -4.7483 & 2.3131 & 0.2794\end{array}$

$\begin{array}{llll}39 \mathrm{H} 39 & -5.2206 & 0.4737 & 1.9153\end{array}$

$\begin{array}{llll}40 \mathrm{H} 40 & -3.7062 & 0.8430 & 2.7566\end{array}$

$41 \mathrm{H} 41 \quad-7.1809 \quad-3.1356 \quad 1.4881$

$\begin{array}{lllll}42 \mathrm{H} 42 & -8.0297 & -1.8310 & 0.6660\end{array}$

$43 \mathrm{H} 43 \quad-7.8574 \quad-3.4142 \quad-0.1399$

$\begin{array}{llll}44 \mathrm{H} 44 & -1.3950 & -1.5223 & 0.1377\end{array}$

$\begin{array}{llll}45 \mathrm{H} 45 & 0.8911 & -0.6879 & -0.3727\end{array}$

$\begin{array}{lllll}46 \mathrm{H} 46 & 1.1292 & 4.0112 & 0.1366\end{array}$

$\begin{array}{lllll}47 \mathrm{H} 47 & 2.9429 & 3.7290 & 0.2420\end{array}$

$48 \mathrm{H} 48 \quad 3.1331 \quad 1.1168 \quad 1.1023$

$\begin{array}{llll}49 \mathrm{H} 49 & 5.2770 & 0.9270 & 1.2219\end{array}$

$\begin{array}{llll}50 \mathrm{H} 50 & 7.2232 & -0.3959 & 2.0366\end{array}$

$\begin{array}{llll}51 \mathrm{H} 51 & 6.1663 & -3.6139 & -0.5843\end{array}$

$\begin{array}{lllll}52 \mathrm{H} 52 & 4.1921 & -2.2810 & -1.4148\end{array}$

$\begin{array}{lllll}53 \mathrm{H} 53 & 1.0546 & 3.8460 & -3.1307\end{array}$

$\begin{array}{llll}54 \mathrm{H} 54 & -0.1141 & 3.1742 & -1.9837\end{array}$

$\begin{array}{llll}55 \mathrm{H} 55 & 0.7085 & 2.1052 & -3.1371\end{array}$

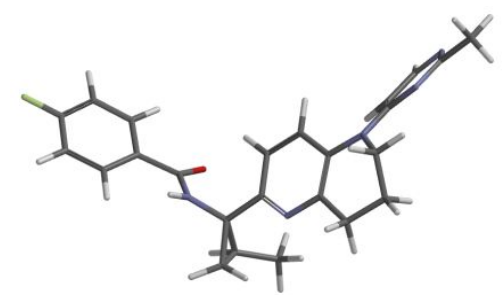

Boltzmann Population $=17.40 \%$ 


\section{Conformer \#3}

Rel. Energy $=0.748 \mathrm{kcal} / \mathrm{mol}$

$\begin{array}{llll}1 \mathrm{C} 1 & -3.7995 & -3.3816 & 0.4755\end{array}$

$\begin{array}{llll}2 \mathrm{~N} 2 & -5.0862 & -3.6217 & 0.1616\end{array}$

$\begin{array}{lllll}3 \mathrm{C} 3 & -5.7997 & -2.5410 & -0.1751\end{array}$

$\begin{array}{llll}4 \mathrm{~N} 4 & -5.3454 & -1.2800 & -0.2464\end{array}$

$\begin{array}{lllll}5 \mathrm{C} 5 & -4.0534 & -1.0594 & 0.0446\end{array}$

$\begin{array}{llll}6 \mathrm{C} 6 & -3.2171 & -2.1293 & 0.4415\end{array}$

$\begin{array}{lllll}7 \text { N7 } & -3.6383 & 0.2607 & -0.0109\end{array}$

$\begin{array}{lllll}8 \mathrm{C} 8 & -2.2803 & 0.6475 & 0.0009\end{array}$

$\begin{array}{llll}9 \text { C9 } & -1.9108 & 1.8262 & 0.6794\end{array}$

$\begin{array}{llll}10 \mathrm{C} 10 & -3.0154 & 2.6846 & 1.2329\end{array}$

$\begin{array}{llll}11 \text { C11 } & -4.1357 & 2.7057 & 0.1804\end{array}$

$\begin{array}{llll}12 \mathrm{C} 12 & -4.6991 & 1.2991 & -0.0325\end{array}$

$\begin{array}{llll}13 \mathrm{C} 13 & -7.2528 & -2.7423 & -0.5140\end{array}$

$\begin{array}{llll}14 \mathrm{C} 14 & -1.2744 & -0.0444 & -0.6861\end{array}$

$\begin{array}{llll}15 \mathrm{C} 15 & 0.0393 & 0.3976 & -0.5966\end{array}$

$\begin{array}{llll}16 \mathrm{C} 16 & 0.3244 & 1.5423 & 0.1613\end{array}$

$\begin{array}{llll}17 \mathrm{~N} 17 & -0.6481 & 2.2530 & 0.7526\end{array}$

$\begin{array}{llll}18 \mathrm{C} 18 & 1.7362 & 2.0479 & 0.2844\end{array}$

19 C19 $2.1701 \quad 3.2812 \quad-0.4994$

$\begin{array}{llll}20 \mathrm{C} 20 & 2.0036 & 3.3616 & 0.9925\end{array}$

$\begin{array}{llll}21 \mathrm{~N} 21 & 2.7470 & 1.0323 & 0.4534\end{array}$

$\begin{array}{lllll}22 & \mathrm{C} 22 & 3.3730 & 0.3988 & -0.5889\end{array}$

$\begin{array}{lllll}23 \mathrm{C} 23 & 4.4418 & -0.5875 & -0.2131\end{array}$

$\begin{array}{lllll}24 & 024 & 3.0804 & 0.6104 & -1.7642\end{array}$

$\begin{array}{lllll}25 \mathrm{C} 25 & 5.1447 & -0.5466 & 0.9998\end{array}$

$\begin{array}{llll}26 \mathrm{C} 26 & 6.1333 & -1.4874 & 1.2816\end{array}$

$\begin{array}{lllll}27 \mathrm{C} 27 & 6.4086 & -2.4667 & 0.3335\end{array}$

$\begin{array}{lllll}28 C 28 & 5.7406 & -2.5264 & -0.8860\end{array}$

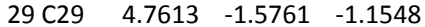

$\begin{array}{llll}30 \text { F30 } & 7.3602 & -3.3817 & 0.6016\end{array}$

$\begin{array}{llll}31 \text { C31 } & 1.2186 & 3.9691 & -1.4504\end{array}$

$\begin{array}{llll}32 \mathrm{H} 32 & 3.1924 & 3.2109 & -0.8609\end{array}$

$\begin{array}{llll}33 \mathrm{H} 33 & -3.2116 & -4.2459 & 0.7798\end{array}$

$\begin{array}{llll}34 \mathrm{H} 34 & -2.1862 & -1.9842 & 0.7337\end{array}$

$\begin{array}{llll}35 \mathrm{H} 35 & -3.4009 & 2.2653 & 2.1731\end{array}$

$\begin{array}{llll}36 \mathrm{H} 36 & -2.6247 & 3.6820 & 1.4468\end{array}$

$\begin{array}{llll}37 \mathrm{H} 37 & -4.9584 & 3.3630 & 0.4794\end{array}$

$\begin{array}{lllll}38 \mathrm{H} 38 & -3.7306 & 3.1029 & -0.7575\end{array}$

$\begin{array}{lllll}39 \mathrm{H} 39 & -5.2500 & 1.2321 & -0.9754\end{array}$

$\begin{array}{llll}40 \mathrm{H} 40 & -5.4110 & 1.0544 & 0.7619\end{array}$

$41 \mathrm{H} 41 \quad-7.8818 \quad-2.1360 \quad 0.1459$

$42 \mathrm{H} 42 \quad-7.4514 \quad-2.4105 \quad-1.5384$

$43 \mathrm{H} 43 \quad-7.5236 \quad-3.7937 \quad-0.4131$

$44 \mathrm{H} 44 \quad-1.5229 \quad-0.9077 \quad-1.2937$

$45 \mathrm{H} 45 \quad 0.8286 \quad-0.0999 \quad-1.1465$

$\begin{array}{llll}46 \mathrm{H} 46 & 1.1301 & 3.8702 & 1.3852\end{array}$

$\begin{array}{llll}47 \mathrm{H} 47 & 2.8949 & 3.4093 & 1.6110\end{array}$

$\begin{array}{lllll}48 \mathrm{H} 48 & 2.8650 & 0.6589 & 1.3840\end{array}$

$\begin{array}{llll}49 \mathrm{H} 49 & 4.9520 & 0.2419 & 1.7208\end{array}$

$\begin{array}{llll}50 \mathrm{H} 50 & 6.6958 & -1.4677 & 2.2082\end{array}$

$\begin{array}{lllll}51 \mathrm{H} 51 & 5.9968 & -3.3036 & -1.5973\end{array}$

$52 \mathrm{H} 52 \quad 4.2282 \quad-1.5762 \quad-2.0991$

$\begin{array}{llll}53 \mathrm{H} 53 & 1.5559 & 4.9909 & -1.6544\end{array}$

$\begin{array}{lllll}54 \mathrm{H} 54 & 0.2089 & 4.0233 & -1.0357\end{array}$

$\begin{array}{lllll}55 \mathrm{H} 55 & 1.1735 & 3.4258 & -2.3998\end{array}$

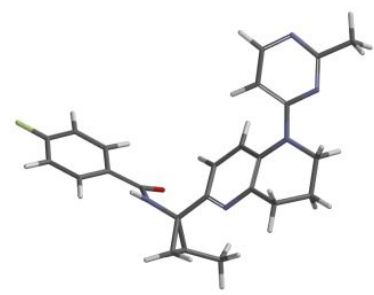

Boltzmann Population $=5.04 \%$ 


\section{Conformer \#4}

Rel. Energy $=0.298 \mathrm{kcal} / \mathrm{mol}$

$\begin{array}{llll}1 \mathrm{C} 1 & -3.8279 & -3.3292 & 0.3910\end{array}$

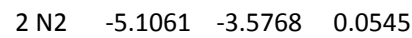

$\begin{array}{lllll}3 \mathrm{C} 3 & -5.8080 & -2.5032 & -0.3309\end{array}$

$\begin{array}{llll}4 \mathrm{~N} 4 & -5.3475 & -1.2483 & -0.4289\end{array}$

$\begin{array}{lllll}5 \mathrm{C} 5 & -4.0626 & -1.0180 & -0.1137\end{array}$

$\begin{array}{lllll}6 \mathrm{C} 6 & -3.2416 & -2.0786 & 0.3349\end{array}$

$\begin{array}{lllll}7 \text { N7 } & -3.6223 & 0.2926 & -0.2251\end{array}$

$\begin{array}{llll}8 \mathrm{C} 8 & -2.2651 & 0.6746 & -0.1054\end{array}$

$\begin{array}{lllll}9 \text { C9 } & -1.9208 & 1.8497 & 0.5906\end{array}$

$\begin{array}{llll}10 \mathrm{C} 10 & -2.9708 & 2.7603 & 1.1928\end{array}$

$\begin{array}{llll}11 \text { C11 } & -4.3842 & 2.1650 & 1.1467\end{array}$

$\begin{array}{lllll}12 \mathrm{C} 12 & -4.5909 & 1.3986 & -0.1625\end{array}$

$\begin{array}{llll}13 \mathrm{C} 13 & -7.2535 & -2.7110 & -0.6979\end{array}$

$\begin{array}{llll}14 \mathrm{C} 14 & -1.2330 & -0.0237 & -0.7518\end{array}$

$\begin{array}{lllll}15 \mathrm{C} 15 & 0.0771 & 0.4071 & -0.6208\end{array}$

$\begin{array}{llll}16 \mathrm{C} 16 & 0.3376 & 1.5524 & 0.1484\end{array}$

$\begin{array}{llll}17 \mathrm{~N} 17 & -0.6498 & 2.2578 & 0.7096\end{array}$

$\begin{array}{llll}18 \mathrm{C} 18 & 1.7454 & 2.0560 & 0.3154\end{array}$

19 C19 $\quad 2.1917 \quad 3.3088-0.4351$

$\begin{array}{llll}20 \mathrm{C} 20 & 1.9960 & 3.3541 & 1.0544\end{array}$

$\begin{array}{llll}21 \mathrm{~N} 21 & 2.7459 & 1.0302 & 0.4881\end{array}$

$\begin{array}{lllll}22 & \mathrm{C} 22 & 3.4059 & 0.4280 & -0.5492\end{array}$

$\begin{array}{lllll}23 \mathrm{C} 23 & 4.4328 & -0.6036 & -0.1743\end{array}$

$\begin{array}{lllll}24 & 024 & 3.1825 & 0.7100 & -1.7249\end{array}$

$\begin{array}{llll}25 \mathrm{C} 25 & 4.4147 & -1.3207 & 1.0308\end{array}$

$\begin{array}{llll}26 \mathrm{C} 26 & 5.3917 & -2.2755 & 1.3066\end{array}$

$\begin{array}{llll}27 \mathrm{C} 27 & 6.3855 & -2.5022 & 0.3609\end{array}$

$\begin{array}{lllll}28 C 28 & 6.4240 & -1.8194 & -0.8511\end{array}$

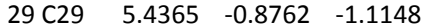

$\begin{array}{llll}30 \text { F30 } & 7.3355 & -3.4204 & 0.6235\end{array}$

$\begin{array}{llll}31 \text { C31 } & 1.2601 & 4.0191 & -1.3890\end{array}$

$\begin{array}{llll}32 \mathrm{H} 32 & 3.2204 & 3.2437 & -0.7782\end{array}$

$\begin{array}{llll}33 \mathrm{H} 33 & -3.2488 & -4.1846 & 0.7351\end{array}$

$\begin{array}{llll}34 \mathrm{H} 34 & -2.2181 & -1.9285 & 0.6496\end{array}$

$\begin{array}{llll}35 \mathrm{H} 35 & -2.6748 & 3.0165 & 2.2153\end{array}$

$36 \mathrm{H} 36 \quad-2.9432 \quad 3.7021 \quad 0.6282$

$\begin{array}{llll}37 \mathrm{H} 37 & -4.5350 & 1.4670 & 1.9786\end{array}$

$\begin{array}{llll}38 \mathrm{H} 38 & -5.1360 & 2.9550 & 1.2464\end{array}$

$\begin{array}{llll}39 \mathrm{H} 39 & -4.4287 & 2.0561 & -1.0258\end{array}$

$\begin{array}{lllll}40 \mathrm{H} 40 & -5.5876 & 0.9704 & -0.2409\end{array}$

$41 \mathrm{H} 41 \quad-7.8964 \quad-2.0845 \quad-0.0711$

$42 \mathrm{H} 42 \quad-7.4268 \quad-2.4095 \quad-1.7361$

$43 \mathrm{H} 43 \quad-7.5294 \quad-3.7584 \quad-0.5724$

$44 \mathrm{H} 44 \quad-1.4695 \quad-0.8851 \quad-1.3671$

$45 \mathrm{H} 45 \quad 0.8814 \quad-0.0966 \quad-1.1426$

$\begin{array}{llll}46 \mathrm{H} 46 & 1.1126 & 3.8498 & 1.4416\end{array}$

$\begin{array}{llll}47 \mathrm{H} 47 & 2.8748 & 3.3951 & 1.6919\end{array}$

$\begin{array}{llll}48 \mathrm{H} 48 & 3.0219 & 0.8161 & 1.4344\end{array}$

$\begin{array}{llll}49 \mathrm{H} 49 & 3.6173 & -1.1703 & 1.7525\end{array}$

$\begin{array}{llll}50 \mathrm{H} 50 & 5.3892 & -2.8483 & 2.2271\end{array}$

$\begin{array}{llll}51 \mathrm{H} 51 & 7.2135 & -2.0373 & -1.5616\end{array}$

$52 \mathrm{H} 52 \quad 5.4189 \quad-0.3350 \quad-2.0543$

$\begin{array}{lllll}53 \mathrm{H} 53 & 1.6021 & 5.0450 & -1.5623\end{array}$

$\begin{array}{lllll}54 \mathrm{H} 54 & 0.2422 & 4.0647 & -0.9940\end{array}$

$\begin{array}{llll}55 \mathrm{H} 55 & 1.2349 & 3.4981 & -2.3515\end{array}$

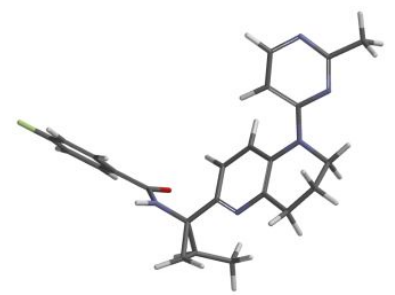

Boltzmann Population $=10.77 \%$ 


\section{Conformer \#5}

\begin{tabular}{|c|c|c|c|}
\hline & & & \\
\hline & & & \\
\hline & & & \\
\hline $\mathrm{N} 4$ & & & \\
\hline C5 & & & \\
\hline C6 & & & \\
\hline v7 & & & \\
\hline C8 & & & \\
\hline$c 9$ & 85 & 1.8607 & \\
\hline C10 & 607 & .8339 & .04 \\
\hline C11 & 957 & 2.1466 & 2.20 \\
\hline C12 & 306 & 0.8974 & 1.717 \\
\hline C13 & 692 & -2.6279 & 0.5 \\
\hline C14 & & -0 & \\
\hline C15 & & & \\
\hline C16 & & & -0 \\
\hline N17 & & & 0.32 \\
\hline C18 & & & \\
\hline 19 & & & \\
\hline$c 20$ & & & \\
\hline N21 & & & \\
\hline C22 & & & \\
\hline $\mathrm{C} 23$ & & & \\
\hline O24 & & & \\
\hline C25 & & & \\
\hline C26 & & & \\
\hline C27 & & & \\
\hline C28 & & & \\
\hline & & & \\
\hline & & & \\
\hline & & & \\
\hline & & & \\
\hline & & & \\
\hline 34 & & & \\
\hline & & & \\
\hline 36 & & & \\
\hline H37 & & & \\
\hline H38 & & & \\
\hline H39 & & & \\
\hline $\mathrm{H} 40$ & & & \\
\hline $\mathrm{H} 41$ & & & \\
\hline $\mathrm{H} 42$ & & & 0.6347 \\
\hline $\mathrm{H} 43$ & & & -0.0991 \\
\hline $\mathrm{H} 44$ & 1377 & & 0.0970 \\
\hline $\mathrm{H} 45$ & 578 & -0. & -0.4081 \\
\hline $\mathrm{H} 46$ & 464 & & -0.0032 \\
\hline H47 & 56 & & 39 \\
\hline$H$ & 87 & & 1.0550 \\
\hline 1 & & & -1.3641 \\
\hline $\mathrm{H5}$ & & & -0.480 \\
\hline & & & 20660 \\
\hline & & & 1.1997 \\
\hline & & & -3.266 \\
\hline & & & - \\
\hline & .7270 & & \\
\hline
\end{tabular}

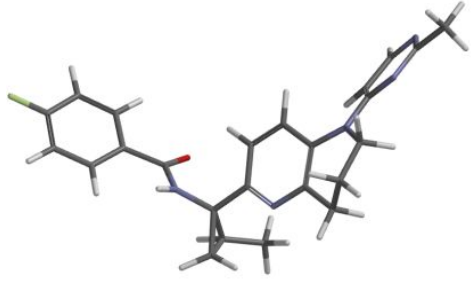

Boltzmann Population $=5.07 \%$ 


\section{Conformer \#6}

Rel. Energy $=0.252 \mathrm{kcal} / \mathrm{mol}$

$\begin{array}{llll}1 \text { C1 } & -4.5099 & -2.2910 & -1.8940\end{array}$

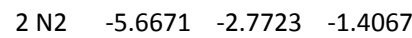

$\begin{array}{lllll}3 \mathrm{C} 3 & -6.0328 & -2.2732 & -0.2189\end{array}$

$\begin{array}{llll}4 \mathrm{~N} 4 & -5.3476 & -1.3822 & 0.5114\end{array}$

$\begin{array}{lllll}5 \mathrm{C} 5 & -4.1811 & -0.9282 & 0.0254\end{array}$

$\begin{array}{lllll}6 \mathrm{C} 6 & -3.7188 & -1.3670 & -1.2365\end{array}$

$\begin{array}{lllll}7 \text { N7 } & -3.5010 & -0.0060 & 0.8089\end{array}$

$\begin{array}{lllll}8 \mathrm{C} 8 & -2.1826 & 0.4288 & 0.5361\end{array}$

$\begin{array}{lllll}9 \mathrm{C} 9 & -1.8414 & 1.7868 & 0.6882\end{array}$

$\begin{array}{llll}10 \mathrm{C} 10 & -2.8465 & 2.8173 & 1.1602\end{array}$

$\begin{array}{llll}11 \mathrm{C} 11 & -4.2745 & 2.2653 & 1.2654\end{array}$

$\begin{array}{llll}12 \mathrm{C} 12 & -4.2443 & 0.8209 & 1.7727\end{array}$

$\begin{array}{lllll}13 \mathrm{C} 13 & -7.3342 & -2.7528 & 0.3674\end{array}$

$\begin{array}{llll}14 \mathrm{C} 14 & -1.1548 & -0.4650 & 0.1969\end{array}$

$\begin{array}{llll}15 \mathrm{C} 15 & 0.1246 & 0.0129 & -0.0356\end{array}$

$\begin{array}{llll}16 \mathrm{C} 16 & 0.3719 & 1.3863 & 0.1150\end{array}$

$\begin{array}{llll}17 \mathrm{~N} 17 & -0.5953 & 2.2343 & 0.4818\end{array}$

$\begin{array}{llll}18 \mathrm{C} 18 & 1.7350 & 1.9566 & -0.1656\end{array}$

$\begin{array}{llll}19 \text { C19 } & 1.9447 & 2.8414 & -1.3935\end{array}$

$\begin{array}{llll}20 \mathrm{C} 20 & 1.9705 & 3.4461 & -0.0182\end{array}$

$\begin{array}{llll}21 \mathrm{~N} 21 & 2.8428 & 1.1054 & 0.1945\end{array}$

$\begin{array}{lllll}22 & \mathrm{C} 22 & 3.3914 & 0.1759 & -0.6487\end{array}$

$\begin{array}{lllll}23 \mathrm{C} 23 & 4.5576 & -0.6039 & -0.1089\end{array}$

$\begin{array}{lllll}24 & 024 & 2.9646 & -0.0155 & -1.7853\end{array}$

$\begin{array}{llll}25 \mathrm{C} 25 & 4.7893 & -0.8145 & 1.2581\end{array}$

$\begin{array}{lllll}26 \mathrm{C} 26 & 5.8839 & -1.5623 & 1.6884\end{array}$

$\begin{array}{lllll}27 \mathrm{C} 27 & 6.7417 & -2.0954 & 0.7328\end{array}$

$\begin{array}{lllll}28 \mathrm{C} 28 & 6.5322 & -1.9186 & -0.6316\end{array}$

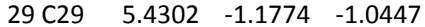

$\begin{array}{llll}30 \text { F30 } & 7.8043 & -2.8152 & 1.1422\end{array}$

$\begin{array}{lllll}31 \text { C31 } & 0.8221 & 3.1059 & -2.3693\end{array}$

$32 \mathrm{H} 32 \quad 2.9126 \quad 2.6796 \quad-1.8594$

$\begin{array}{llll}33 \mathrm{H} 33 & -4.2108 & -2.6617 & -2.8730\end{array}$

$34 \mathrm{H} 34 \quad-2.8147 \quad-0.9852 \quad-1.6904$

$\begin{array}{llll}35 \mathrm{H} 35 & -2.5089 & 3.1720 & 2.1431\end{array}$

$36 \mathrm{H} 36 \quad-2.7994 \quad 3.6874 \quad 0.4970$

$\begin{array}{llll}37 \mathrm{H} 37 & -4.8786 & 2.8898 & 1.9321\end{array}$

$\begin{array}{llll}38 \mathrm{H} 38 & -4.7632 & 2.2718 & 0.2840\end{array}$

$\begin{array}{llll}39 \mathrm{H} 39 & -5.2398 & 0.3949 & 1.8756\end{array}$

$\begin{array}{llll}40 \mathrm{H} 40 & -3.7417 & 0.7626 & 2.7462\end{array}$

$41 \mathrm{H} 41 \quad-7.1612 \quad-3.2178 \quad 1.3432$

$\begin{array}{lllll}42 \mathrm{H} 42 & -8.0092 & -1.9063 & 0.5313\end{array}$

$\begin{array}{llll}43 \mathrm{H} 43 & -7.8082 & -3.4725 & -0.3007\end{array}$

$44 \mathrm{H} 44 \quad-1.3675 \quad-1.5254 \quad 0.1160$

$45 \mathrm{H} 45 \quad 0.9163 \quad-0.6590 \quad-0.3414$

$\begin{array}{llll}46 \mathrm{H} 46 & 1.1116 & 4.0244 & 0.3042\end{array}$

$\begin{array}{lllll}47 \mathrm{H} 47 & 2.9269 & 3.7541 & 0.3954\end{array}$

$\begin{array}{llll}48 \mathrm{H} 48 & 3.2795 & 1.2753 & 1.0877\end{array}$

$\begin{array}{llll}49 \mathrm{H} 49 & 4.0982 & -0.4300 & 2.0023\end{array}$

$\begin{array}{llll}50 \mathrm{H} 50 & 6.0744 & -1.7461 & 2.7397\end{array}$

$\begin{array}{llll}51 \mathrm{H} 51 & 7.2235 & -2.3619 & -1.3396\end{array}$

$\begin{array}{lllll}52 \mathrm{H} 52 & 5.2198 & -1.0311 & -2.0984\end{array}$

$\begin{array}{llll}53 \mathrm{H} 53 & 1.0426 & 3.9943 & -2.9707\end{array}$

$\begin{array}{llll}54 \mathrm{H} 54 & -0.1261 & 3.2741 & -1.8531\end{array}$

$\begin{array}{llll}55 \mathrm{H} 55 & 0.7022 & 2.2541 & -3.0465\end{array}$

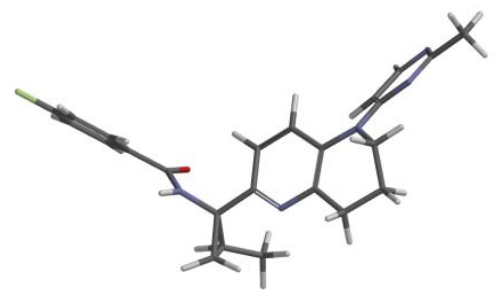

Boltzmann Population $=11.64 \%$ 


\section{Determination of Absolution Stereoconfiguration of compound $\mathbf{5}$}

The Experimental versus Calculated IR and VCD spectra are shown below. Calculations are from the Boltzmann-weighted average spectra.

$-\operatorname{Exp}$

- Calc 18S, 19S

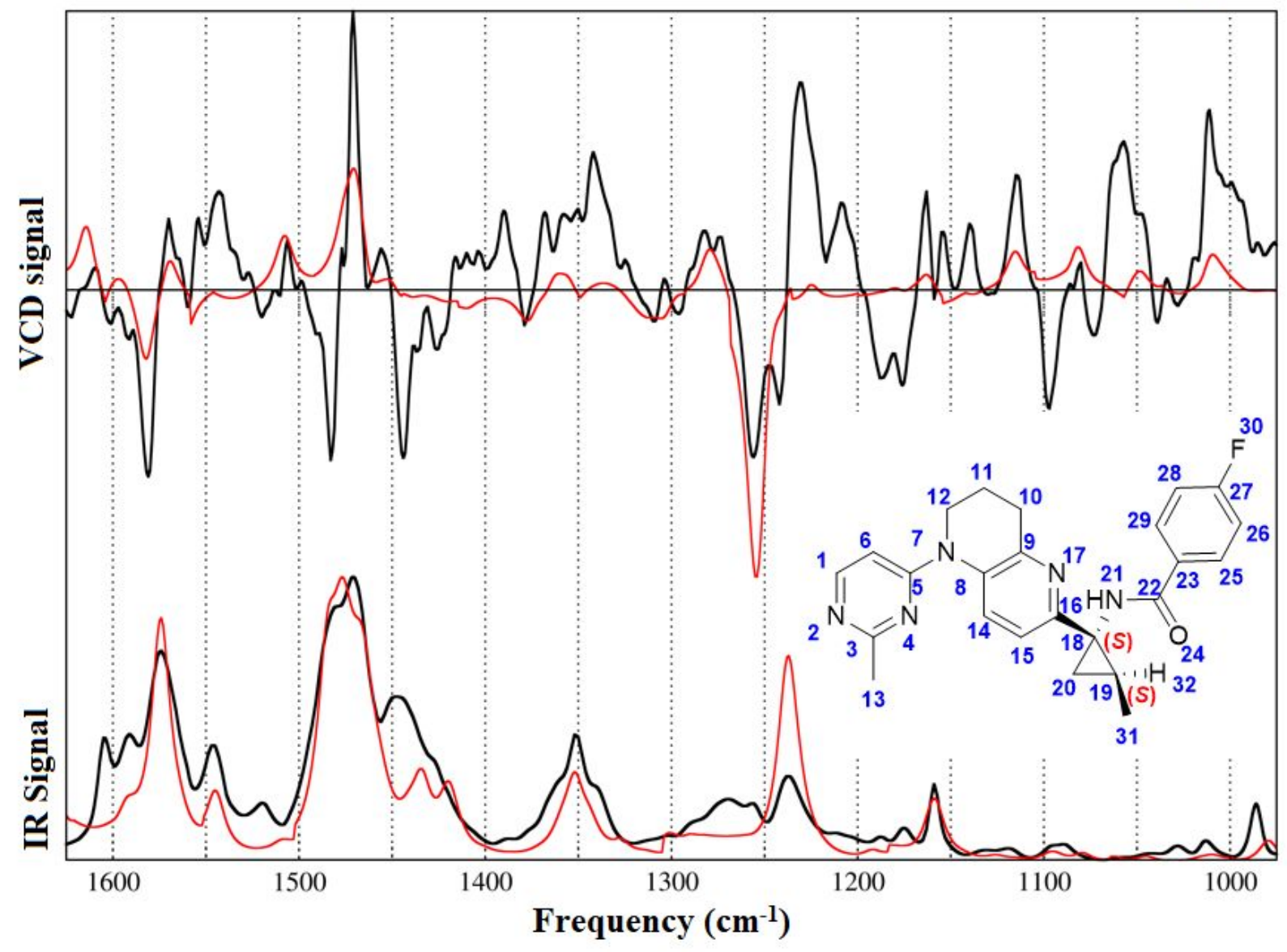

Integrated Comparison Results

Maximum shift of IR \& VCD spectral bands $=25 \mathrm{~cm}^{-1}$

Unshifted IR $=0.686$

Final Shifted IR $=0.876$

Unshifted VCD for $(18 S, 19 S)=0.010$

Final Shifted VCD for $(18 S, 19 S)=0.235$

Unshifted VCD for enantiomer $(18 R, 19 R)=-0.010$

Final Shifted VCD for enantiomer $(18 R, 19 R)=0.092$

\section{Conclusions}

VCD calculations exhibit a moderate quality match for the $(18 S, 19 S)$ configuration. 


\section{References for absolute stereochemistry determination using VCD experiments}

1. Sherer, E.C.; Lee, C.H.; Shpungin, J.; Cuff, J.F.; Da, C.X.; Ball, R.; Bach, R.; Crespo, A.; Gong, X.Y.; Welch, C.J. J. Med. Chem. 2014, 57, 477.

2. Liu, Z.Q.; Shultz, C.S.; Sherwood, C.A.; Krska, S.; Dormer, P.G.; Desmond, R.; Lee, C.; Sherer, E.C.; Shpungin, J.; Cuff, J.; Xu, F. Tetrahedron. Lett. 2011, 52, 1685.

3. Petersson, G.A.; Allahan, M.A. J. Chem. Phys. 1991, 94, 6081.

4. Petersson, G.A.; Bennett, A.; Tensfeldt, T.G.; Allahan, M.A.; Shirley, W.A.; Mantzaris, J. J. Chem. Phys. 1988, 89, 2193.

5. Rassolov, V.A.; Pople, J.A.; Ratner, M.A.; Windus, T.L. J. Chem. Phys. 1998, 109, 1223.

6. Rassolov, V.A.; Ratner, M.A.; Pople, J.A.; Redfern, P.C.; Curtiss, L.A. J. Comput. Chem. 2001, 22, 976.

7. Francl, M.M.; Pietro, W.J.; Hehre, W.J.; Binkley, J.S.; Gordon, M.S.; Defrees, D.J.; Pople, J.A. J. Chem. Phys. 1982, 77, 3654.

8. Hehre, W.J.; Ditchfield, R.; Pople, J.A. J. Chem. Phys. 1972, 56, 2257.

9. Becke, A.D. J. Chem. Phys. 1993, 98, 5648.

10. Lee, C.T.; Yang, W.T.; Parr, R.G. Phys. Rev. B 1998, 37, 785.

11. Miehlich, B.; Savin, A.; Stoll, H.; Preuss, H. Chem. Phys. Lett. 1989, 157, 200.

12. Gaussian '16, Revision A.03, M. J. Frisch, G. W. Trucks, H. B. Schlegel, G. E. Scuseria, M. A. Robb, J. R. Cheeseman, G. Scalmani, V. Barone, G. A. Petersson, H. Nakatsuji, X. Li, M. Caricato, A. V. Marenich, J. Bloino, B. G. Janesko, R. Gomperts, B. Mennucci, H. P. Hratchian, J. V. Ortiz, A. F. Izmaylov, J. L. Sonnenberg, D. Williams-Young, F. Ding, F. Lipparini, F. Egidi, J. Goings, B. Peng, A. Petrone, T. Henderson, D. Ranasinghe, V. G. Zakrzewski, J. Gao, N. Rega, G. Zheng, W. Liang, M. Hada, M. Ehara, K. Toyota, R. Fukuda, J. Hasegawa, M. Ishida, T. Nakajima, Y. Honda, O. Kitao, H. Nakai, T. Vreven, K. Throssell, J. A. Montgomery, Jr., J. E. Peralta, F. Ogliaro, M. J. Bearpark, J. J. Heyd, E. N. Brothers, K. N. Kudin, V. N. Staroverov, T. A. Keith, R. Kobayashi, J. Normand, K. Raghavachari, A. P. Rendell, J. C. Burant, S. S. Iyengar, J. Tomasi, M. Cossi, J. M. Millam, M. Klene, C. Adamo, R. Cammi, J. W. Ochterski, R. L. Martin, K. Morokuma, O. Farkas, J. B. Foresman, and D. J. Fox, Gaussian, Inc., Wallingford CT, 2016.

13. Cheeseman, J.R.; Frisch, M.J.; Devlin, F.J.; Stephens, P.J. Chem. Phys. Lett. 1996, 252, 211. 